\title{
(ब)
}

INSTITUTO DE PESQUISAS ENERGÉTICAS E NUCLEARES

Autarquia associada à Universidade de São Paulo

Estudo do processo de fabricação de placas combustíveis com uma dispersão a base de gama U7Mo

MARINA CÔRTES PIRES

Dissertação apresentada como parte dos requisitos para obtenção do Grau de Mestre em Ciências na área de Tecnologia Nuclear - Materiais

Orientador:

Prof. Dr. Michelangelo Durazzo

Co-orientador:

Prof. Dr. Ricardo Mendes Leal Neto 


\title{
INSTITUTO DE PESQUISAS ENERGÉTICAS E NUCLEARES
}

Autarquia associada à Universidade de São Paulo

\section{Estudo do processo de fabricação de placas combustíveis com uma dispersão a base de gama U7Mo}

\author{
Versão Corrigida
}

Versão Original disponível no IPEN

\section{MARINA CÔRTES PIRES}

Dissertação apresentada como parte dos requisitos para obtenção do Grau de Mestre em Ciências na área de Tecnologia Nuclear - Materiais

Orientador:

Prof. Dr. Michelangelo Durazzo

Co-orientador:

Prof. Dr. Ricardo Mendes Leal Neto

\section{São Paulo}


Autorizo a reprodução e divulgação total ou parcial deste trabalho, para fins de estudo e pesquisa, desde que citada a fonte

Como citar:

PIRES, M. Estudo do processo de fabricação de placas combustíveis com uma dispersão a base de gama U7Mo. 2020. 82 p. Dissertação (Mestrado em Tecnologia Nuclear), Instituto de Pesquisas Energéticas e Nucleares, IPEN-CNEN/SP, São Paulo. Disponível em: (data de consulta no formato: $\mathrm{dd} / \mathrm{mm} / \mathrm{aaaa}$ )

Ficha catalográfica elaborada pelo Sistema de geração automática da Biblioteca IPEN/USP, com os dados fornecidos pelo(a) autor(a)

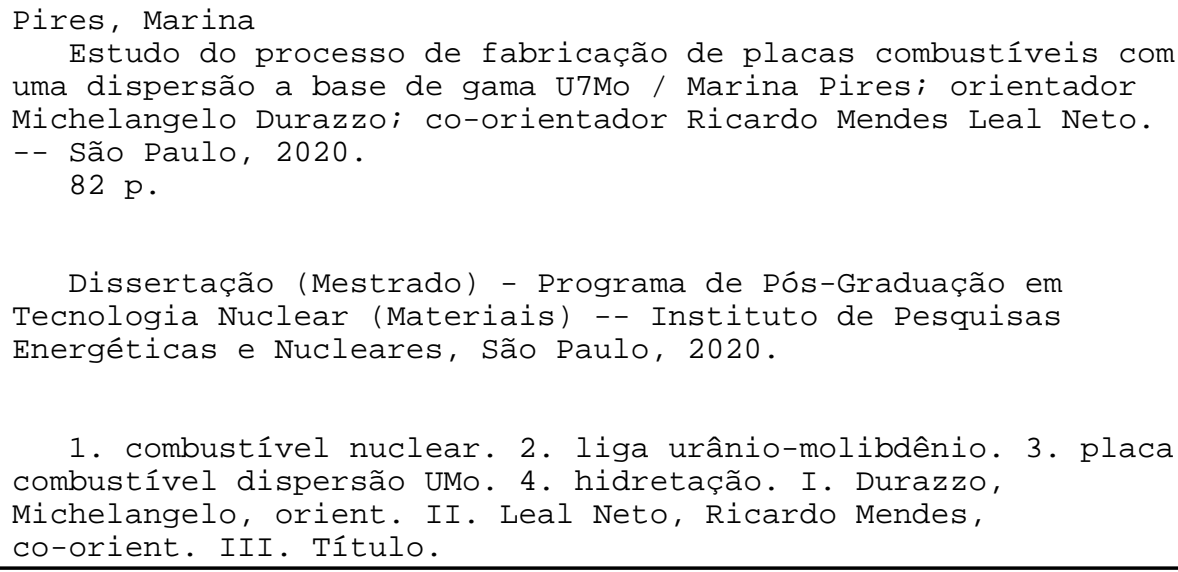


Dedico este trabalho ao nascimento do meu sobrinho

Lucas Luchesi Côrtes 


\section{Agradecimento}

Ao professor Dr. Michelangelo Durazzo pela receptividade para me orientar neste trabalho e por todo conhecimento adquirido ao longo das atividades desenvolvidas.

Ao professor Dr. Ricardo Mendes Leal Neto pelas orientações, aulas e discussões que ajudaram a enriquecer este trabalho.

Ao colega José Ronaldo de Oliveira Marques pelo empenho na preparação dos sistemas utilizados e pela confiança na continuidade de seu trabalho.

A todos os pesquisadores e técnicos do Centro do Combustível Nuclear (CCN/IPEN) que contribuíram para a realização desta pesquisa.

Às amizades adquiridas no IPEN, pela companhia, troca de experiências e convivência durante estes anos.

Aos membros da banca que disponibilizaram de seu tempo para agregar conhecimento a este trabalho

A todos da Secretaria de Pós-Graduação (SPG) pela receptividade e presteza em todos os momentos.

À Marinha do Brasil que, através do Centro Tecnológico da Marinha em São Paulo, permitiu a oportunidade de desenvolver meu conhecimento técnico na área do combustível nuclear.

Ao Capitão de Mar e Guerra Ricardo Koji Yamamoto que sempre apoiou minha carreira e me incentivou ao estudo do combustível nuclear tipo placa.

Aos amigos da Marinha que sempre estiveram me apoiando neste novo desafio.

Aos meus familiares que são meu porto seguro e estão sempre ao meu lado me incentivando e acreditando no meu potencial

À força criadora chamada Deus por todas as oportunidades e bençãos recebidas em minha vida. 
"Eu não falhei, encontrei 10 mil soluções que não davam certo." (Thomas Alva Edison) 


\title{
RESUMO
}

PIRES, M. C.. ESTUdO DO PROCESSO DE FABRICAÇÃO DE PLACAS COMBUSTÍVEIS COM UMA DISPERSÃO A BASE DE GAMA-U7MO. 2019. 74 p. Dissertação (Mestrado em Tecnologia Nuclear), Instituto de Pesquisas Energéticas e Nucleares, IPEN-CNEN/SP, São Paulo

\begin{abstract}
A busca de novos materiais para combustíveis nucleares vem sendo desenvolvida ao longo dos últimos 50 anos com o principal intuito de aumentar a eficiência dos combustíveis durante a operação de reatores nucleares. Os programas de redução de enriquecimento de urânio desde a década de 70 são os principais impulsionadores para a busca de materiais que possibilitam o aumento da densidade de urânio nos combustíveis nucleares com baixo enriquecimento (até 20\%). O molibdênio é um elemento que, mesmo em baixas concentrações, consegue reter a fase gama do urânio, estabilizando o elemento combustível durante o processo de fabricação e quando irradiado. Sendo assim, a liga de $\gamma \mathrm{U}$-Mo apresenta grande potencial para desenvolvimento de combustíveis com maior densidade de urânio no núcleo do combustível nuclear. O presente trabalho visa o desenvolvimento tecnológico das etapas de produção de um novo combustível nuclear tipo dispersão a base de uma liga de urânio com 7\% em massa de molibdênio em matriz de alumínio. Nestas condições, é possível obter um combustível com uma densidade de urânio de até $7 \mathrm{gU} \mathrm{cm}^{-3}$ em contraponto ao combustível de siliceto de urânio com $4 \mathrm{gU} \mathrm{cm}^{-3}$ qualificado atualmente. Dentre as etapas previamente já conhecidas pelo IPEN para a fabricação do combustível nuclear, a liga de $\gamma \mathrm{U}$-Mo necessita de um processo específico de pulverização devido às propriedades mecânicas do material. A cominuição da liga foi feita através da técnica de hidretaçãomoagem-desidretação que ainda necessita de estudos mais detalhados de seu processo para sua reprodutibilidade e otimização. As etapas de fabricação do briquete e laminação foram executadas de acordo com a expertise do IPEN. Os resultados indicam que a liga de $\gamma \mathrm{U}-\mathrm{Mo}$, embora, seja mecanicamente factível em todas as etapas de fabricação do combustível nuclear, são necessários ajustes nas condições atuais do processo de fabricação para adequação às propriedades da liga e especialmente para evitar oxidação do núcleo da placa combustível.
\end{abstract}

Palavras-chave: combustível nuclear, urânio-molibdênio, dispersão U7Mo-Al, hidretação, laminação, placa combustível 


\begin{abstract}
PIRES, M. C.. STUDY OF THE MANUFACTURING PROCESS OF GAMMA-U7Mo DISPERSION FUEL PLATES. 2019. 74 p. Dissertação (Mestrado em Tecnologia Nuclear), Instituto de Pesquisas Energéticas e Nucleares, IPENCNEN/SP, São Paulo
\end{abstract}

The search for new materials for nuclear fuels has been developed over the last 50 years, with the main aim of increasing the fuel efficiency during the operation of the reactors. The need to increase the uranium density in fuels to compensate the reduction of enrichment proposes that the U-Mo alloy is one of the materials that presents better characteristics to be used as fuel: molybdenum is a material that retains the gamma phase of the uranium in low concentrations, which is the only stable phase of uranium under the irradiation conditions, besides having low thermal neutron absorption. Although more advanced studies already provide information on the interaction between UMo and the Al matrix, we still need to study how this material behaves during all processing steps for fuel fabrication. The present work has the objective of to deepen the technological knowledge about the stages of production of dispersion type nuclear fuel, including the comminution process of the UMo alloy. The alloy pulverization made by the hydriding-grinding-dehydriding technique still reveals a large number of unknowns in the process variables. Knowing some parameters already existent in the literature, it is possible to discuss the behavior of the hydriding process and envision improvements to optimize it as well as make it reproducible. Subsequent manufacturing steps for briquette and rolling were performed according to IPEN's expertise and the results indicate that the $\gamma \mathrm{U}-\mathrm{Mo}$ alloy, though being mechanically doable, it is necessary adjust the actual fabrication process to the new mechanical alloy properties and to avoid the oxidation of the core of fuel plate.

Key words: nuclear fuel, uranium-molibdenum, dispersion fuel plate U7Mo-Al, hydriding 


\section{SUMÁRIO}

1. INTRODUÇÃ

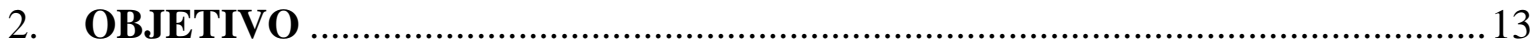

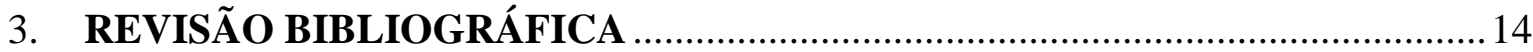

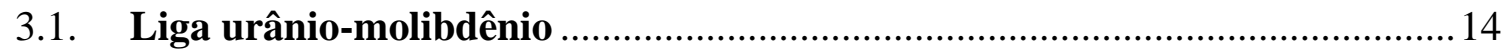

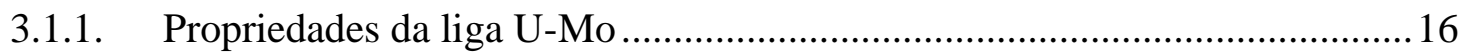

3.1.2. Urânio-Molibdênio como combustível Nuclear ........................................... 17

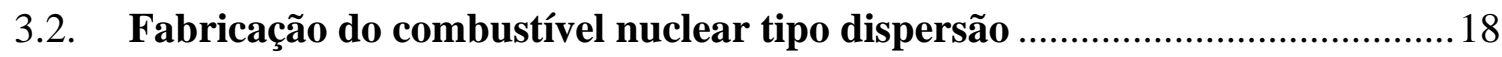

3.2.1. Fabricação do urânio metálico ..................................................................... 19

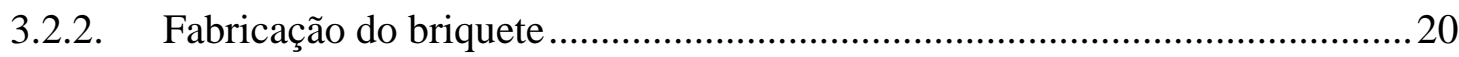

3.2.3. Montagem e laminação de placas combustíveis ........................................... 20

3.2.4. Defeitos de fabricação do combustível...................................................... 22

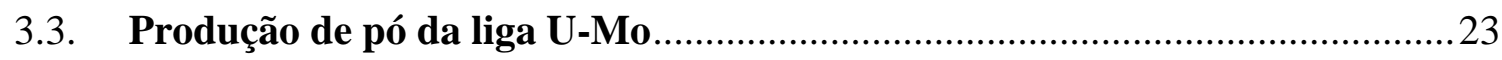

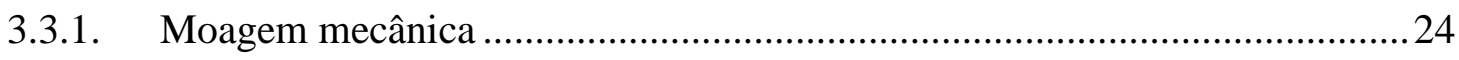

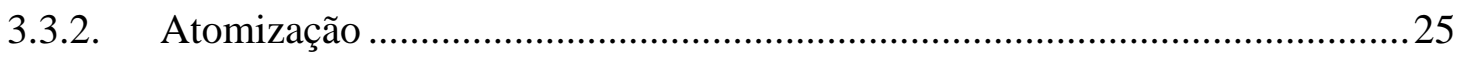

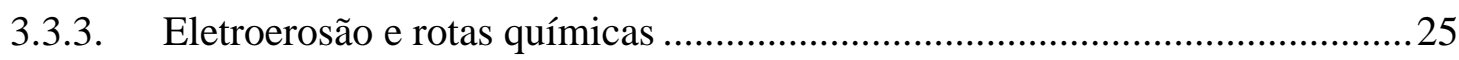

3.3.4. Hidretação, moagem e desidretação .......................................................... 25

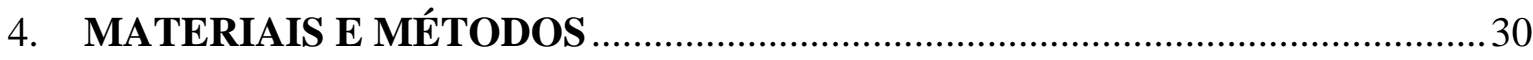

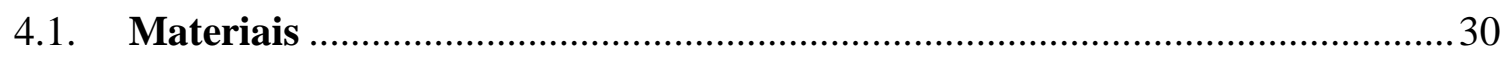

4.1.1. Urânio …........................................................................................ 30

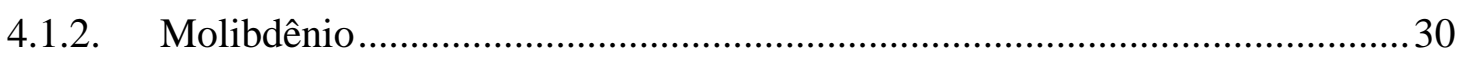

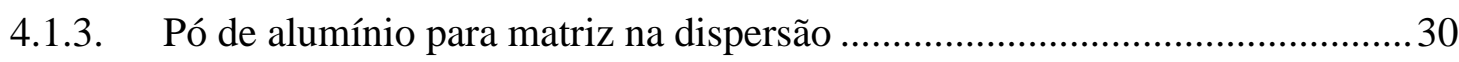

4.1.4. Chapas de alumínio para moldura e revestimento ......................................... 30

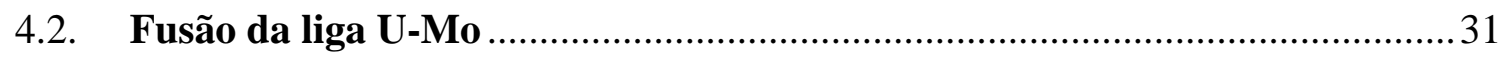

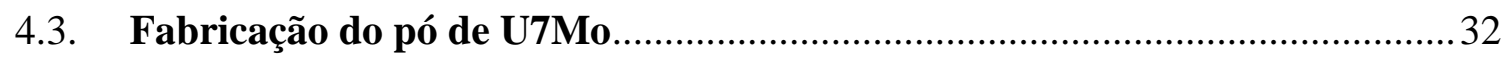

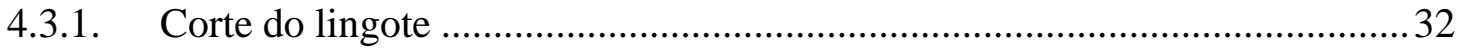

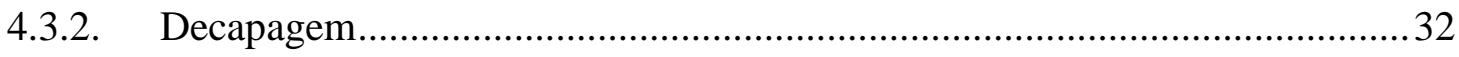

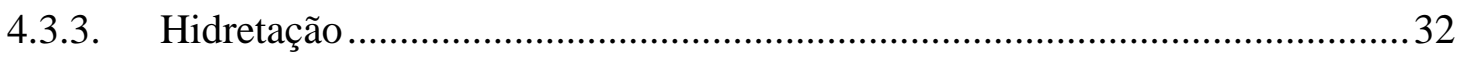

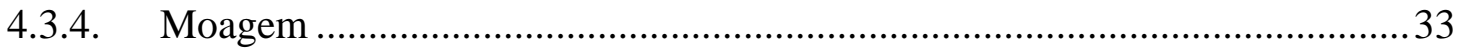

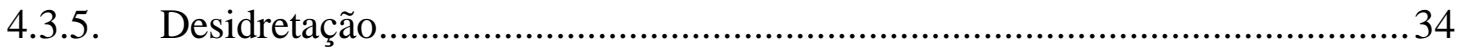

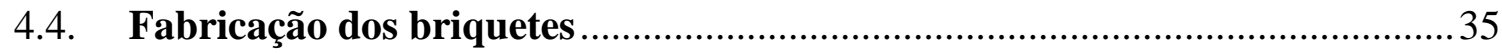




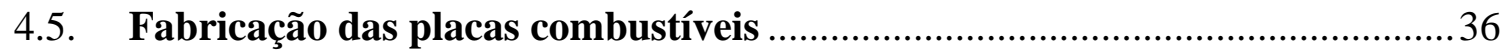

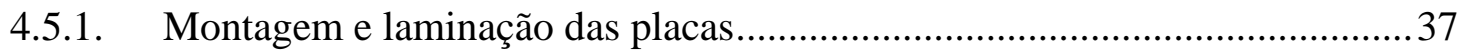

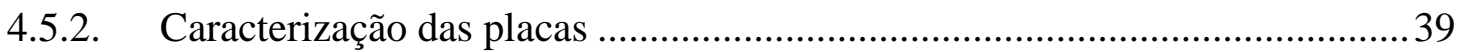

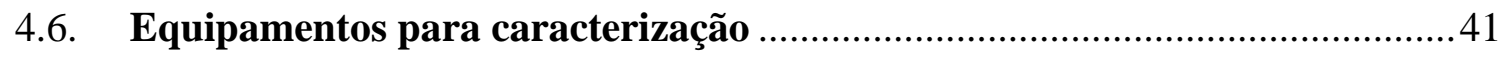

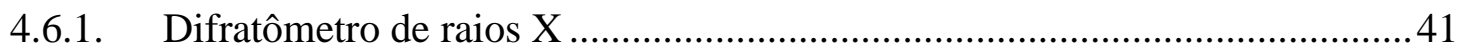

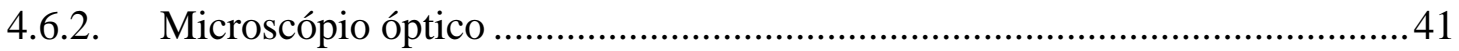

4.6.3. Microscópio eletrônico de varredura ............................................................... 41

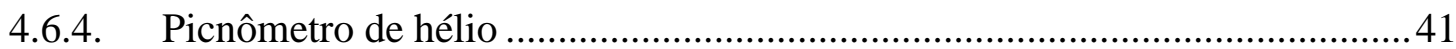

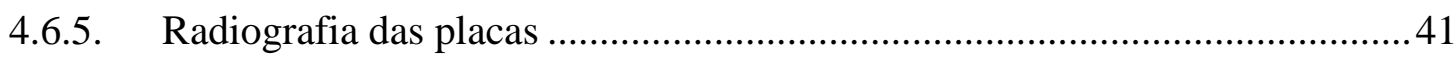

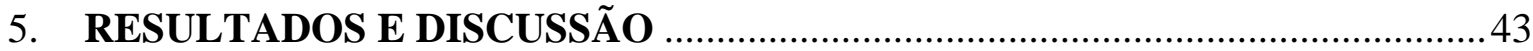

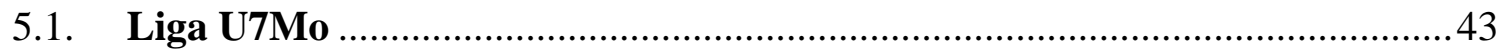

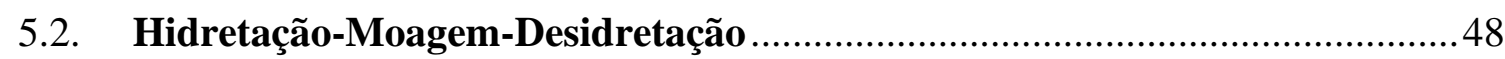

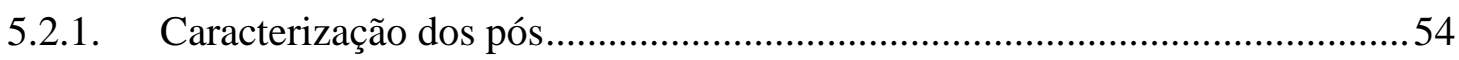

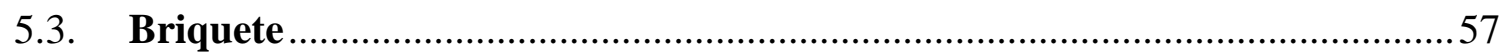

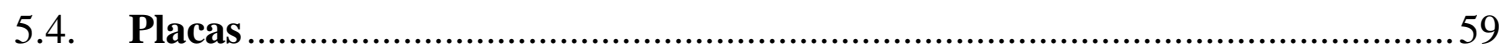

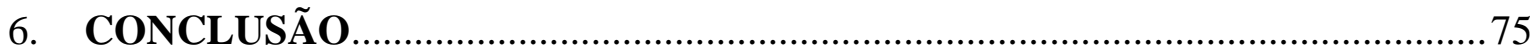

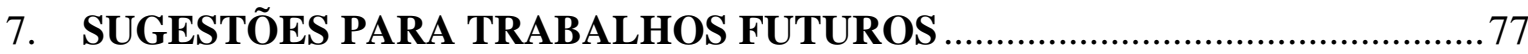




\section{INTRODUÇÃO}

Os reatores nucleares são sistemas que promovem uma reação de fissão controlada e podem ser divididos em reatores de potência e reatores de pesquisa de acordo com sua finalidade. Os primeiros são projetados para a geração de energia elétrica, já o segundo grupo incorpora uma variada gama de atividades como: produção de radioisótopos, estudos de propriedades neutrônicas, estudos dos efeitos da irradiação nos materiais, entre outras [1].

Reatores de pesquisa são menores, sua potência máxima pode chegar até 200 MW, operam a baixas temperaturas mas em condições mais severas se considerarmos a densidade de potência podendo atingir cerca de $17 \mathrm{~kW} \mathrm{~cm}^{-3}$. Reatores para geração de energia trabalham na faixa de 3000 MW de potência com uma densidade de aproximadamente $5 \mathrm{~kW} \mathrm{~cm}{ }^{-3}$. $\mathrm{O}$ enriquecimento nos reatores de pesquisa também é maior, cerca de $20 \%$, quando comparados aos reatores de potência cujo enriquecimento varia de 3 a 5\%. Por estas razões os combustíveis são diferentes para ambos reatores: para os de pesquisa normalmente são utilizados combustíveis tipo placa, já para os de potência é comumente empregado o combustível tipo vareta [2].

Na década de 1970, a preocupação com a proliferação de armamento nuclear, fez com que os Estados Unidos restringissem a comercialização de urânio com alto grau de enriquecimento (acima de $20 \%$ em peso de ${ }^{235} \mathrm{U}$ ) afetando a operação de vários reatores nucleares ao redor do mundo. Em decorrência disto, surgiram programas que visavam o desenvolvimento de combustíveis com baixo enriquecimento (até $20 \%$ em peso de ${ }^{235} \mathrm{U}$ ) para substituição nos mais de 150 reatores de pesquisa em operação. O principal programa é o RERTR (do inglês Reduced Enrichment for Research in Test Reactors) ligado ao Departamento de Energia dos Estados Unidos, ativo ainda nos dias de hoje. Desde o início do programa em 1978, mais de 70 reatores já foram convertidos de combustíveis com alto enriquecimento - HEU (do inglês High Enrichment Uranium) para baixo enriquecimento LEU (do inglês Low Enrichment Uranium), 30 reatores foram descomissionados e processos 
tem sido desenvolvidos para a produção de radioisótopos com alvos de baixo enriquecimento [3].

Neste período, eram utilizados, em sua maioria, combustíveis tipo placa, onde o material físsil era, geralmente, uma liga de urânio-alumínio contendo $18 \%$ em massa de urânio altamente enriquecido. Para compensação do baixo enriquecimento, foi preciso aumentar a concentração de urânio nas placas. Desta maneira as propriedades físicas e mecânicas dos materiais tornaram-se limitadoras ao desenvolvimento de novos combustíveis, por exemplo, as ligas de U-Al com 45\% em massa de U se tornaram frágeis e propensas à segregação comprometendo a operação do reator $[4,5]$.

A redução do enriquecimento necessita de um aumento significativo da concentração de urânio o que modifica propriedades mecânicas e térmicas do combustível e, consequentemente, o seu desempenho sob irradiação.

Um dos maiores problemas encontrado nos compostos com alto teor de urânio em combustíveis do tipo dispersão em matriz de alumínio é sua instabilidade dimensional sob irradiação no reator. Esta instabilidade provoca o inchamento das placas prejudicando a troca térmica do sistema comprometendo a segurança durante a operação. Em meados de 1988, com base em resultados de testes de irradiação, o combustível a base da dispersão $\mathrm{U}_{3} \mathrm{Si}_{2}$-Al foi qualificado pela Comissão Regulatória Nuclear Americana e liberado para comercialização com densidades de urânio de até $4,8 \mathrm{gU} \mathrm{cm}^{-3}$ no núcleo $[6,7,8]$.

Alguns reatores de pesquisa com alto fluxo neutrônico ainda não puderam ser convertidos de HEU para LEU. Para estes reatores, é necessária uma densidade de urânio de 6 a $9 \mathrm{gU} \mathrm{cm}^{-3}$ no núcleo do combustível. O grande desafio para o desenvolvimento de novos combustíveis com baixo enriquecimento é alcançar a máxima densidade de urânio sem a perda das propriedades mecânicas dos materiais.

Na figura 1.1 são mostrados valores de densidade de urânio em relação a fração volumétrica da fase físsil na dispersão obtidos para diferentes compostos de urânio. 
Figura 1.1 - Densidade de urânio no núcleo do combustível em função da fração volumétrica da fase físsil na dispersão para diferentes compostos de urânio

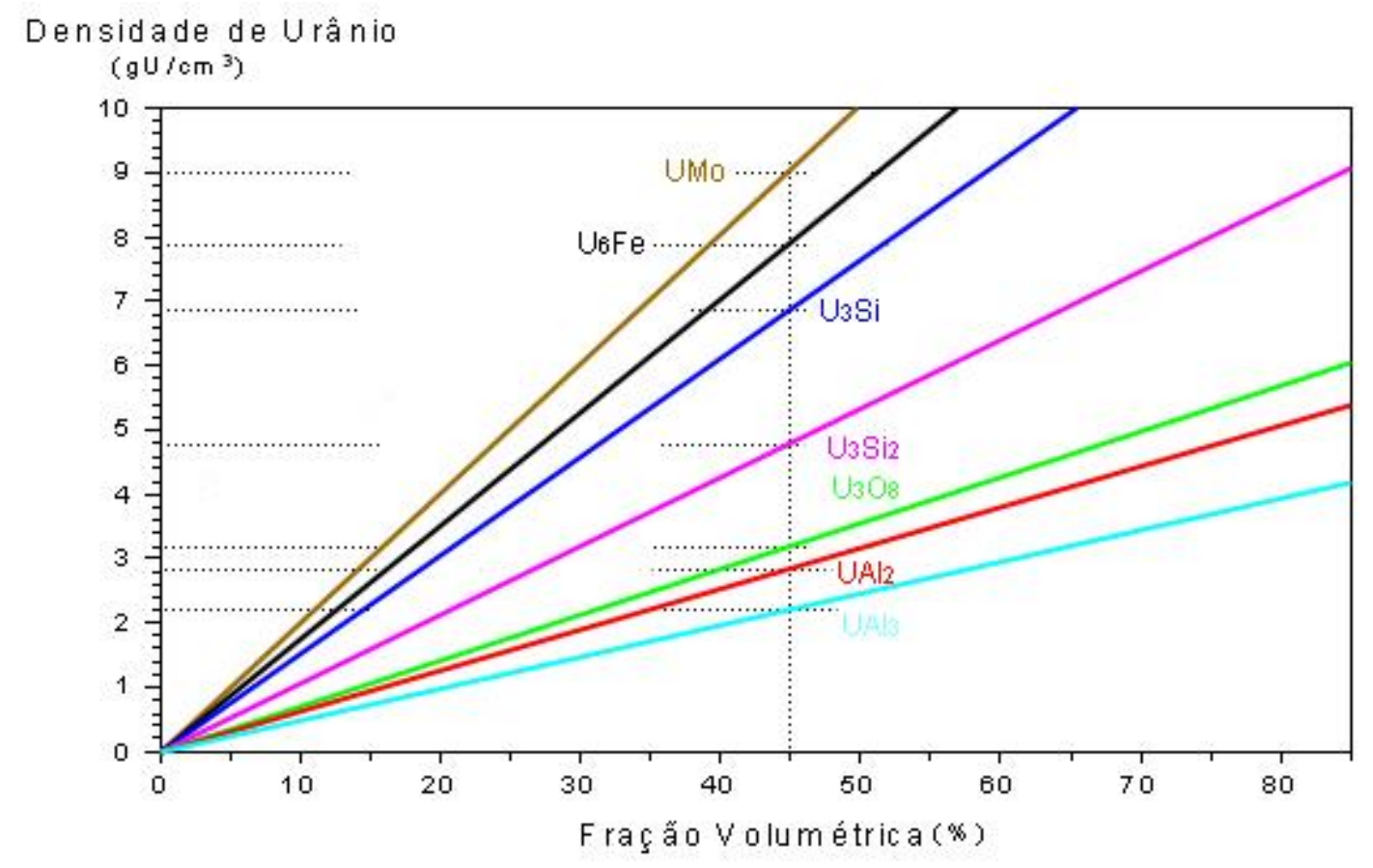

Fonte: [9]

Atualmente, no Brasil parte da produção de radiofármacos é feita no reator IEAR1 instalado no Instituto de Pesquisas Energéticas - IPEN, sendo sua primeira criticalidade atingida em 16 de setembro de 1957. Sua potência máxima é de 5 MW e a configuração do seu núcleo inclui 24 elementos combustíveis, dentre os quais 4 são projetados para inserção das barras de controle. Os outros 20 elementos são compostos por 18 placas combustíveis planas paralelas cada um, montadas em dois suportes laterais de alumínio. As placas combustíveis contém um cerne onde está localizado o material físsil revestido por 2 placas de alumínio. [8]

O IEA-R1 já operou com os seguintes combustíveis:

- Liga U-Al contendo $1,8 \mathrm{gU} \mathrm{cm}^{-3}$ com $20 \%$ de enriquecimento (19571976);

- Liga U-Al contendo $0,6 \mathrm{gU} \mathrm{cm}^{-3}$ com 93,15\% de enriquecimento (19681997) 
- $\mathrm{UAl}_{\mathrm{x}}$ disperso em matriz de $\mathrm{Al}$ contendo $1,9 \mathrm{gU} \mathrm{cm}^{-3}$ com $20 \%$ de enriquecimento (1981-1996)

- $\mathrm{U}_{3} \mathrm{O}_{8}$ disperso em matriz de $\mathrm{Al}$ contendo $1,9 \mathrm{gU} \mathrm{cm}^{-3}$ com $19,9 \%$ de enriquecimento (1988-2004)

- $\mathrm{U}_{3} \mathrm{O}_{8}$ disperso em matriz de $\mathrm{Al}$ contendo $2,3 \mathrm{gU} \mathrm{cm}^{-3}$ com 19,9\% de enriquecimento (desde 1996)

- $\mathrm{U}_{3} \mathrm{Si}_{2}$ disperso em matriz de $\mathrm{Al}$ contendo $3,0 \mathrm{gU} \mathrm{cm}^{-3}$ com 19,9\% de enriquecimento (desde 1999)

Neste breve histórico, nota-se a tendência do aumento do teor de urânio nos combustíveis.

Para o atual combustível $\mathrm{U}_{3} \mathrm{Si}_{2}$, a densidade de urânio é de $11,3 \mathrm{gU} \mathrm{cm} \mathrm{cm}^{-3}$, já em ligas U-Mo este valor pode chegar a $17 \mathrm{gU} \mathrm{cm}^{-3}$. Por isso, as ligas $\gamma \mathrm{U}$-Mo são possíveis candidatas para substituição do siliceto de urânio. Diversas pesquisas estão sendo realizadas para a obtenção deste combustível, desde variação de composição da liga, técnicas de fabricação do combustível e ensaios de irradiação [10].

Para o IPEN, o interesse no desenvolvimento de combustível com maior densidade de urânio é sua utilização no futuro Reator Multipropósito Brasileiro - RMB. 


\section{OBJETIVO}

Este trabalho tem como objetivo investigar o processo de fabricação de placas combustíveis com uma dispersão de urânio com $7 \%$ em massa de molibdênio em alumínio - U7Mo-Al nas seguintes etapas:

- fusão e preparação da liga U7Mo

- cominuição do pó de U7Mo através do processo de hidretação-moagemdesidretação

- compactação e fabricação do briquete

- laminação e fabricação da placa

As placas serão fabricadas com densidades de urânio nos valores de $4 \mathrm{gU} \mathrm{cm}^{-3} \mathrm{e}$ $7 \mathrm{gU} \mathrm{cm}^{-3}$ para análise da influência do aumento de material combustível em todo o processo de fabricação. 


\section{REVISÃO BIBLIOGRÁFICA}

\subsection{Liga urânio-molibdênio}

O urânio apresenta-se em três diferentes formas cristalográficas: uma fase $\alpha$ ortorrômbica com densidade de $18,97 \mathrm{~g} \mathrm{~cm}^{-3}$ e estável até a $667{ }^{\circ} \mathrm{C}$, uma fase $\beta$ tetragonal com densidade de $18,11 \mathrm{~g} \mathrm{~cm}^{-3}$ e estável em temperaturas entre 688 e $776{ }^{\circ} \mathrm{C}$, e por fim, uma fase $\gamma$ cúbica de corpo centrado com densidade de 18,06 $\mathrm{g} \mathrm{cm}^{-3}$ e estável entre 776 e 1132 ${ }^{\circ} \mathrm{C}$. A fase $\alpha$ do urânio é altamente suscetível à corrosão, e é anisotrópica, gerando instabilidade dimensional durante ciclagem térmica e irradiação em reatores. A fase $\gamma$ confere estabilidade dimensional e resistência à corrosão ao combustível, embora não seja termodinamicamente estável em temperaturas abaixo de $776^{\circ} \mathrm{C}[10,11]$.

Diversos metais formam soluções sólidas com o urânio permitindo reter a fase $\gamma \mathrm{U}$ em um estado metaestável após resfriamento. A estabilização da fase $\gamma \mathrm{U}$ ocorre com a presença de outros elementos químicos em solução sólida através da hibridização de orbitais nas ligações atômicas [11]. Os resultados dos testes em reatores de pesquisa para desenvolvimento de novos combustíveis demonstram que o molibdênio apresenta um bom compromisso entre a concentração de molibdênio necessária para estabilização da fase $\gamma \mathrm{U}$ e a densidade de urânio a ser atingida em combustíveis com baixo enriquecimento, especialmente para concentrações acima de $6 \%$ em massa $[11,12]$.

O molibdênio apresenta pouca solubilidade nas fases $\alpha$ e $\beta$ do urânio. A fase $\gamma$ exibe uma solubilidade máxima em cerca de $17 \%$ em massa de molibdênio. Em $565{ }^{\circ} \mathrm{C}$ com aproximadamente $12 \%$ em massa, a fase $\gamma$ sofre uma reação eutetóide transformando-se na fase ortorrômbica $\alpha-U$ e uma fase tetragonal ordenada, $\delta$, (também conhecida na literatura como $\gamma^{\prime}$ ) que tem a estequiometria $\mathrm{U}_{2}$ Mo. O diagrama de fases do sistema U-Mo é apresentado na figura 3.1 .

A fase gama pode ser retida em temperatura ambiente através de tratamento térmico ou através de um resfriamento rápido em toda a faixa de concentração de molibdênio [12]. Na figura 3.2 são comparadas curvas de tempo, temperatura e transformação para 
diferentes concentrações de molibdênio no material. Quanto maior a concentração de Mo, maior será a renteção da fase $\gamma \mathrm{U}$ na liga.

Figura 3.1 - Diagrama de fases U-Mo até 19\% em massa

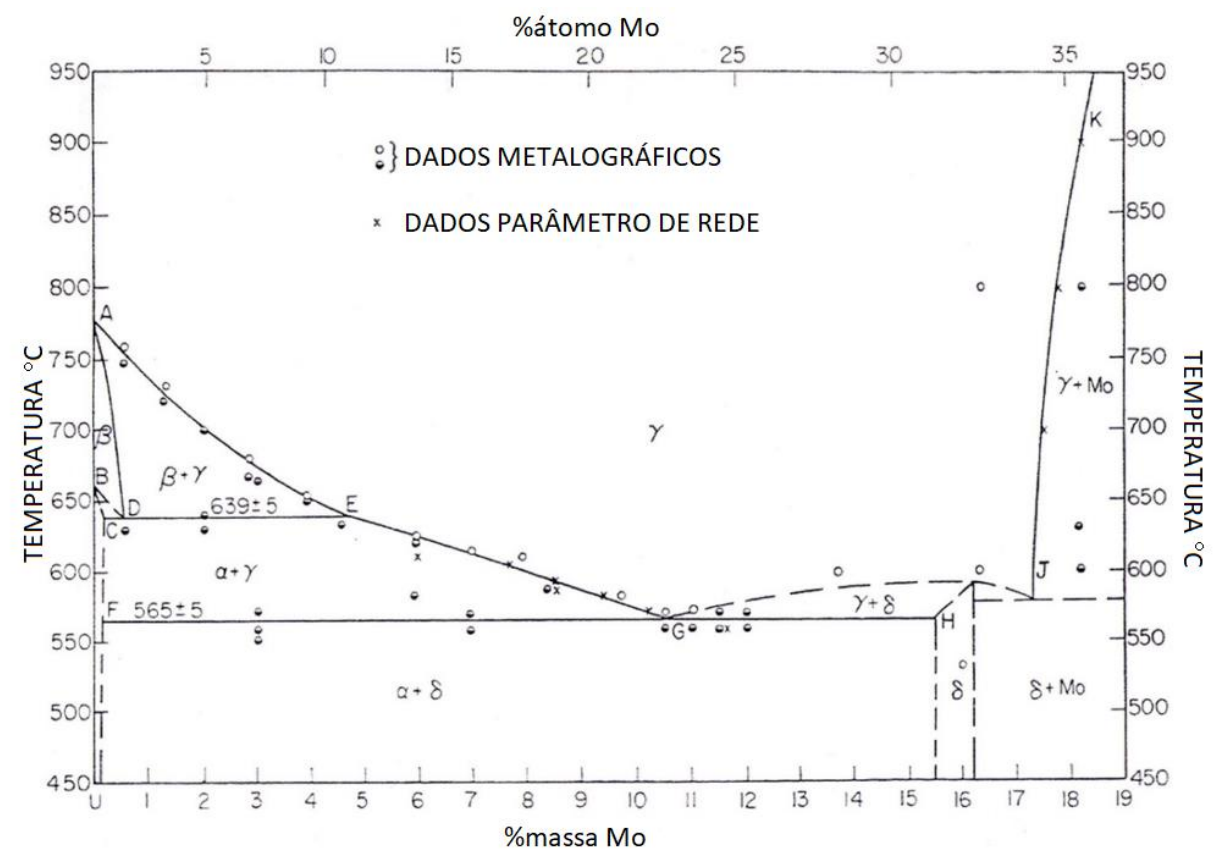

Fonte: [12] adaptada pelo autor

Figura 3.2 - Curvas de tempo, temperatura e transformação para diferentes \% em átomo de molibdênio após tratamento térmico a $1000{ }^{\circ} \mathrm{C}$

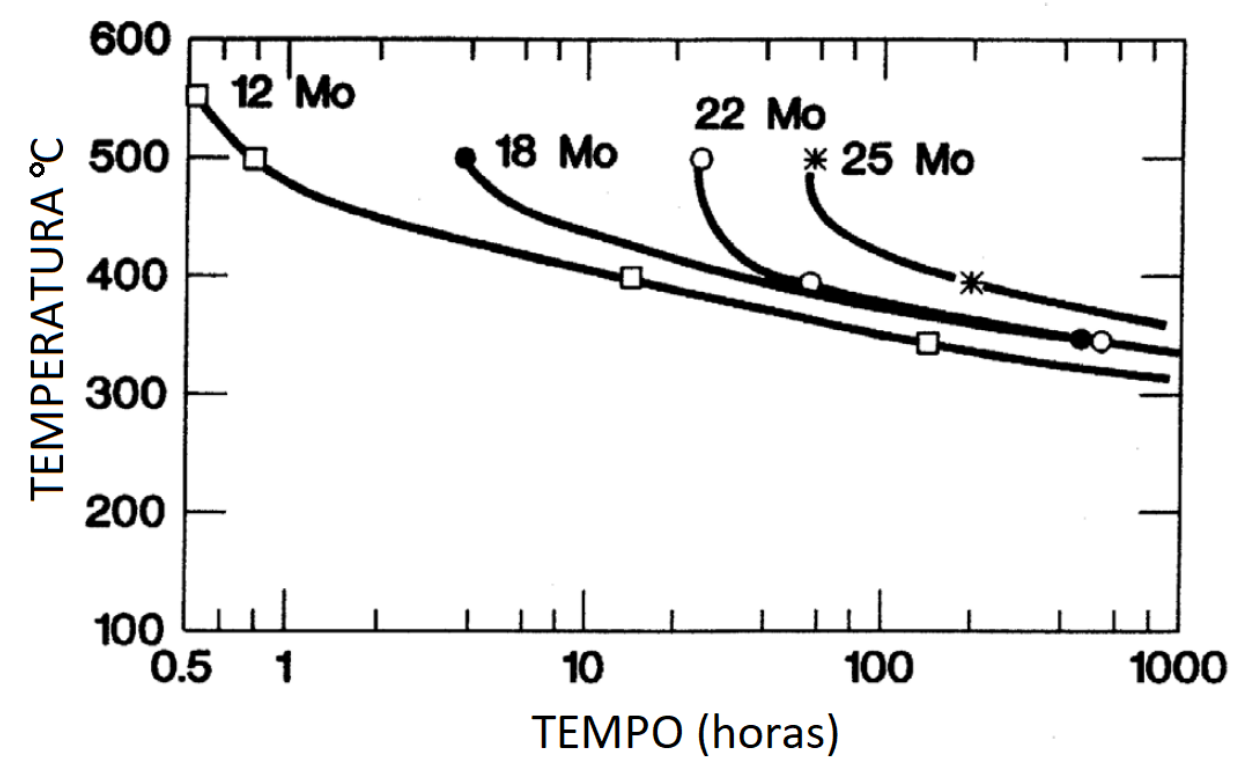

Fonte: [10] adaptada pelo autor 


\subsubsection{Propriedades da liga U-Mo}

A estabilidade estrutural é necessária para não ocorrer deformações nos combustíveis a fim de não prejudicar o funcionamento termo-hidráulico do reator. No caso da liga U-Mo, embora a fase $\gamma U$ se apresente estável, testes de irradiação mostraram que sob certas condições ocorre um inchamento excessivo e imprevisível na placa do elemento combustível. Este inchamento é proveniente da reação entre o U-Mo com a matriz de $\mathrm{Al}$ da dispersão [10].

A condutividade térmica é outro fator importante para um combustível nuclear já que todo o fundamento do reator nuclear se baseia na troca térmica com o núcleo do combustível. É observada a diminuição da condutividade térmica com o aumento do teor de Mo. Desta maneira é necessário atingir um ponto ótimo entre o teor de Mo e parâmetro físico em questão [10].

Como foi dito, diversos outros metais de transição também são capazes de estabilizar a fase $\gamma U$. Entretanto o molibdênio apresenta uma baixa seção de choque de absorção de nêutrons térmicos $\left(\sigma_{N}\right)$ em relação aos outros elementos. A baixa $\sigma_{N}$ permite que o Mo esteja presente no meio da reação nuclear sem interferir de maneira acentuada, permitindo que a reação continue crítica.

As propriedades mecânicas das ligas U-Mo impactam o processo de fabricação do combustível. A liga U-Mo é dúctil o que dificulta a moagem mecânica tradicional. A dureza tende a crescer com o aumento do teor de molibdênio na faixa de 7 a $14 \%$ em peso de Mo, podendo ser potencializada por tratamento térmico até uma concentração de $10 \%$. O aumento da concentração de Mo em ligas de U alteram as propriedades mecânicas do metal, diminuindo sua ductilidade $[10,13,14,15,16,17]$. Adições crescentes de molibdênio endurecem o reticulado do urânio de forma progressiva, tornando-o mais resistente ao cisalhamento [11].

Técnicas de metalurgia do pó são estudadas a fim de se obter o pó com as características que atendam as especificações granulométricas e morfológicas para combustíveis do tipo dispersão.

O processo de laminação do briquete formado pela liga U-Mo dispersa em Al também apresenta dificuldades devido à diferença entre as propriedades mecânicas e 
densidade dos dois materiais sujeitando a deformação e não fragmentação das partículas e segregação das mesmas no núcleo.

\subsubsection{Urânio-Molibdênio como combustível Nuclear}

Estudos com U-Mo são realizados desde a década de 1950. Entretanto, a redução do grau de enriquecimento nos combustíveis nucleares na década de 1970 foi responsável pela aceleração na busca de novos materiais para compensar o baixo enriquecimento.

Os testes de irradiação do programa RERTR com combustíveis a base de UMo foram iniciados há mais de 20 anos. O primeiro teste foi de 94 dias de irradiação com uma média de queima entre 39 e 45\%. Já no segundo teste, o combustível foi irradiado por 232 dias com uma queima entre 65 e $71 \%$. A temperatura em ambos os experimentos foi de $65{ }^{\circ} \mathrm{C}$ na linha central do combustível. As amostras irradiadas variaram a concentração de Mo entre 4 a 10\% em massa. Os resultados indicaram duas conclusões principais: 1) a microestrutura inicial da liga tem um significativo efeito sobre o comportamento dos gases de fissão; e 2) a proporção de Mo na liga tem efeito na taxa de reação da matriz com o núcleo combustível. As amostras com 6\% ou mais de Mo apresentaram melhor estabilidade em relação aos gases de fissão, com pequenas bolhas distribuídas pelo núcleo. As amostras com menores concentrações de Mo exibiram extensa interação com a matriz de Al e largas bolhas dos gases de fissão. Logo, o aumento da concentração de Mo apresenta menor inchamento durante a irradiação [12]. Ainda no programa RERTR, o terceiro teste visou a substituição dos combustíveis em reatores de pesquisa de alta potência, aumentando a densidade de urânio de $4 \mathrm{gU} \mathrm{cm}^{-3}$ para $8 \mathrm{gU} \mathrm{cm}^{-3}$ atingindo temperaturas acima de $200{ }^{\circ} \mathrm{C}$.

A comparação do RERTR-3 com os testes anteriores verificaram que o grau de inchamento dependente da temperatura é devido interação de U-Mo na matriz de Al. Esta interação gera um produto com baixa condutividade térmica que resulta em um aumento de temperatura em pontos isolados do combustível [18].

Os testes posteriores avaliaram o aumento da queima do combustível, assim como o desenvolvimento de um combustível monolítico de U-Mo. Os resultados confirmaram a estabilidade da liga de U-Mo em temperaturas acima de $300{ }^{\circ} \mathrm{C}$, sendo a interação com o $\mathrm{Al}$ o fator de inchamento mais impactado pela temperatura. Os ensaios também testaram o combustível monolítico que apresentou dados otimistas para a fabricação 
de um combustível com densidades de urânio superiores a $8 \mathrm{gU} \mathrm{cm}^{-3}$ [19]. Para minimizar a interação U-Mo-Al foram realizados novos testes com adição de silício na matriz para atenuar o inchamento provocado por este fenômeno de interação [20].

Em paralelo, na Europa o programa IRIS apresentou resultados semelhantes com a pesquisa através de ligas ternárias e alternativas para barrar a interdifusão entre a liga combustível e a matriz e, também, o efeito da morfologia da partícula combustível durante o processo de queima [21,22].

O estágio mais desenvolvido de combustíveis U-Mo está relatado no projeto KJRR que está construindo um reator de pesquisa que utilizará o combustível com $8 \mathrm{gU} \mathrm{cm} \mathrm{cm}^{-3}$ para operar cerca de 300 dias por ano com uma queima de $60 \%$. O combustível de U-Mo ainda não é utilizado em nenhum outro reator de pesquisa no mundo e para tanto precisa ser qualificado. Os testes de irradiação estão sendo realizados com cooperação do INL e ANL. Já foi realizado um teste de irradiação no ATR do INL por 216 dias com 83\% de queima. Adicionalmete, a primeira mini-placa foi irradiada em HANARO da KAERI com queima máxima de $65 \%$. Os resultados não apresentaram anormalidades na estabilidade geométrica do combustível [23].

\subsection{Fabricação do combustível nuclear tipo dispersão}

O combustível tipo placa é o combustível mais comum para reatores de pesquisa produtores de radioisótopos. Sua estrutura consiste em placas de alumínio espaçadas regularmente, permitindo o fluxo contínuo de água que serve tanto como refrigerante para o calor gerado durante a fissão como moderador para a reação nuclear.

As placas combustíveis possuem um núcleo (briquete) contendo o material físsil que é inteiramente revestido por uma moldura e cobertura de alumínio [2]. O núcleo do combustível pode ser monolítico ou a base de uma dispersão. O primeiro tipo é a própria liga metálica de urânio que irá constituir o núcleo da placa combustível. Já o segundo tipo consiste em um briquete formado por partículas de combustível dispersas em uma matriz, geralmente de alumínio [24].

As etapas de fabricação da placa combustível tipo dispersão estão resumidas na figura 3.3 e são descritas nos itens a seguir. 
Figura 3.3 - Esquema resumido das etapas de fabricação da placa combustível nuclear tipo dispersão

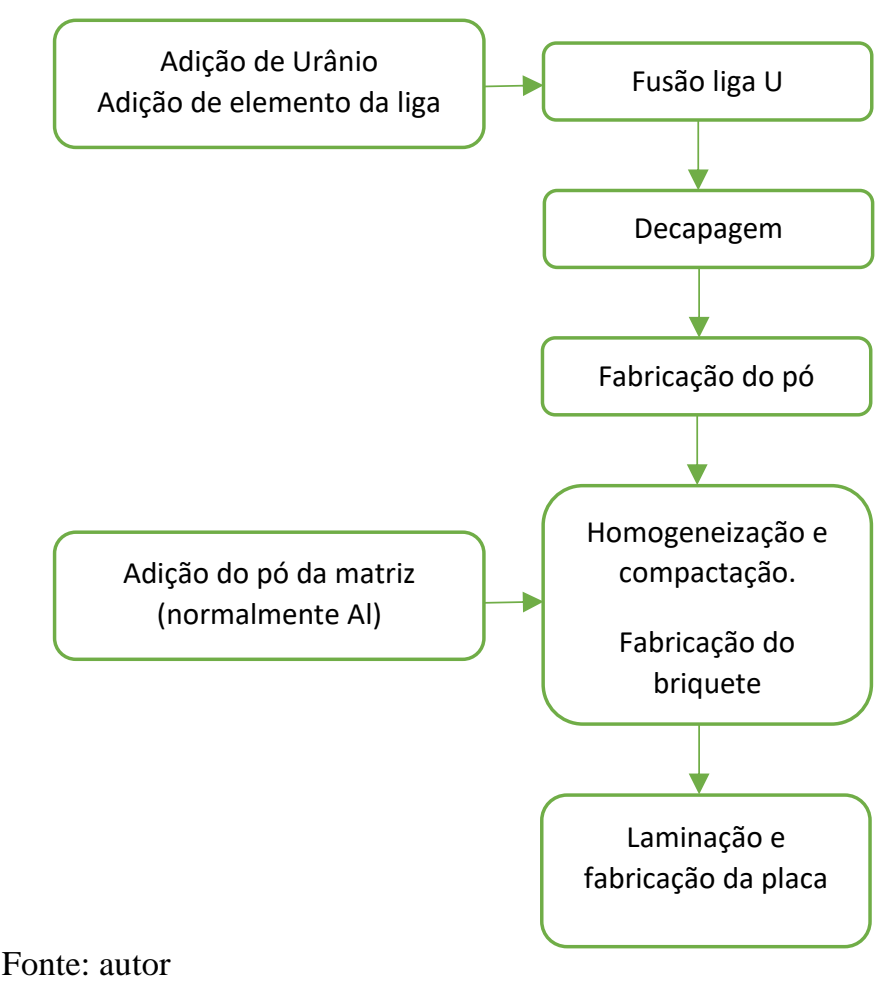

3.2.1. Fabricação do urânio metálico

A fabricação do combustível a partir do UF6 enriquecido passa por uma série de reações químicas para obtenção do urânio metálico. O hexafluoreto de urânio sofre uma reação de hidrólise e em seguida uma redução formando o tetrafluoreto de urânio $\left(\mathrm{UF}_{4}\right)$. O urânio metálico é obtido por uma reação de magnesiotermia, onde o $\mathrm{UF}_{4}$ reage com magnésio metálico num forno resistivo aquecido a $600{ }^{\circ} \mathrm{C}$, a reação é apresentada a seguir na equação 1 [24]

$$
U F_{4}+2 M g^{o} \rightarrow U^{o}+2 M g F_{2}
$$

Com a obtenção do urânio metálico, é possível produzir a liga de urânio designada para o combustível. A fusão da liga pode ser realizada em fornos a arco ou de indução. Os metais são pesados nas proporções desejadas e fundidos. Após a fabricação do lingote, o metal será pulverizado numa faixa granulométrica própria para uso em combustíveis do tipo dispersão [2]. A etapa de cominuição para U-Mo por ser um processo ainda em desenvolvimento pelo IPEN será melhor detalhada no item 3.3. 


\subsubsection{Fabricação do briquete}

O briquete é formado pelo material físsil pulverizado e pelo pó de alumínio metálico que corresponde a matriz estrutural da peça. É uma peça retangular com as quinas arredondadas que será deformada durante a laminação diminuindo sua espessura e aumentando seu comprimento e largura.

A principal especificação para a fabricação do briquete é a quantidade de ${ }^{235} \mathrm{U}$ necessária em cada reator. Desta maneira, de acordo com a estequiometria do composto de urânio utilizado como combustível, a massa total do mesmo é determinada. A dimensão do briquete é definida a partir de sua deformação durante a laminação até o tamanho final do núcleo especificado na placa combustível. A diferença entre o volume da matriz cujo briquete será compactado e do volume do composto de urânio proverá a quantidade de alumínio a ser inserido no briquete [2].

Uma das mais importantes operações na preparação da dispersão trata da homogeneidade da distribuição das partículas combustíveis na matriz. Se a distribuição for irregular, haverá regiões com concentrações de material físsil acima da média, podendo causar instabilidade mecânica nas placas durante a operação do reator. Além disto, regiões com concentração maior que a especificada de material físsil gera distribuição não uniforme dos fluxos de calor causando diferentes pontos de calor e consequente superaquecimento localizados. A homogeneidade é obtida através de uma mistura eficiente que irá diminuir as chances de segregação das partículas [24].

Após a mistura do combustível com a matriz, a etapa que finaliza a fabricação dos briquetes é a compactação. Esta etapa também possibilita que haja segregação entre os pós, assim é preciso atentar para parâmetros, tais como, tamanho, forma e distribuição das partículas de combustível e alumínio; tipo de misturador, tempo de mistura e técnica de transferência do pó para a compactação [2].

Antes da montagem das placas, os briquetes são inspecionados com relação às dimensões, massa, possíveis defeitos superficiais e nas bordas.

\subsubsection{Montagem e laminação de placas combustíveis}

A próxima etapa é a montagem e laminação do conjunto briquete, uma placa de moldura e duas placas de revestimento superior e inferior de alumínio. Ao final da operação 
de laminação, é obtida uma placa com um núcleo combustível completamente isolado do meio exterior devido ao caldeamento entre o núcleo, a moldura e os revestimentos.

A montagem é feita com o encaixe do briquete na moldura previamente aquecida apoiada na placa de revestimento inferior. Em seguida, a outra placa de revestimento é posicionada por cima. Este conjunto é soldado nas 4 arestas, com o cuidado de deixar as extremidades livres para escape de ar nas primeiras operações de laminação.

Primeiramente, ocorre uma laminação a quente, onde os conjuntos soldados são inseridos previamente num forno por cerca de 1 hora à temperatura de 450 a $500{ }^{\circ} \mathrm{C}$. Normalmente, a soldagem a quente varia entre 6 a 10 passes, dependendo da espessura final desejada para a placa. Para o controle de defeitos as placas devem ser rotacionadas longitudinalmente e transversalmente entre os passes. Ao final da laminação a quente, é feito uma inspeção para verificação se houve formação de bolhas. Em sequência, segue-se a laminação a frio que provê uma maior uniformidade e precisão na espessura da placa, além da resistência mecânica da mesma. Após os processos de laminação a quente e a frio, é obtida uma redução na espessura da placa de cerca de $85 \%$. [2]

Ao final, a placa é radiografada para verificação das condições do núcleo em seu interior. Como exemplo, são verificados o comprimento final do núcleo e a homogeneidade da dispersão das partículas combustíveis. A porosidade também é um fator observado, visto que após as etapas de laminação, especialmente da laminação a frio, ocorre considerável fragmentação nas partículas combustíveis aumentando o número de vazios. Em casos com o siliceto de urânio, a porosidade pode aumentar de 5\% no briquete para $8 \%$ após a laminação a frio [2].

A próxima etapa é o corte final da placa nas dimensões especificadas. O núcleo é perfeitamente identificado através de uma chapa radiográfica e o corte é feito com base nesta informação. As placas passam por um processo de limpeza química e qualificação antes de serem montadas como elemento combustível. As etapas de montagem e laminação podem ser representadas pela figura 3.4. 
Figura 3.4 - Esquema de montagem e laminação da placa combustível
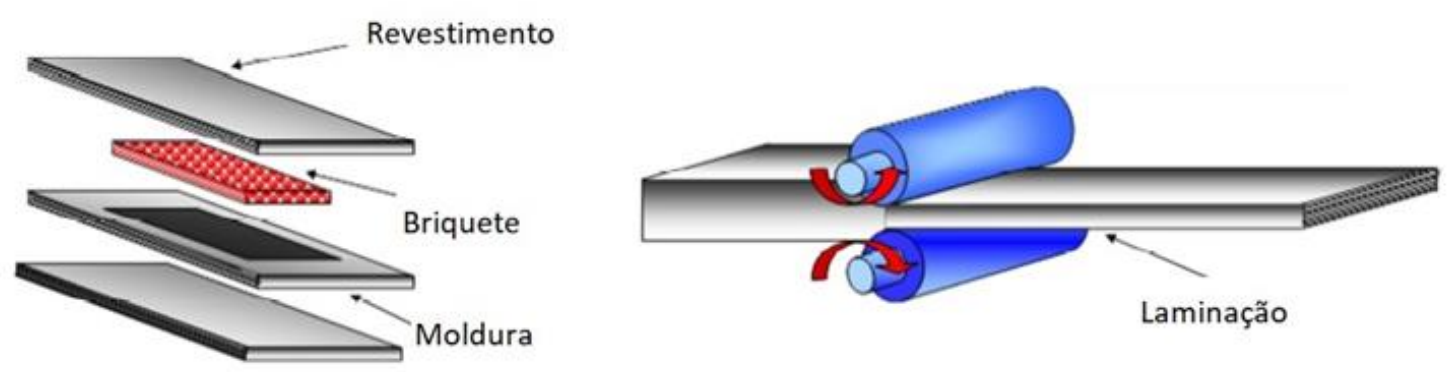

Fonte: [24] adaptada pelo autor

\subsubsection{Defeitos de fabricação do combustível}

A produção de combustíveis prevê a ocorrência de fenômenos inerentes às etapas de fabricação denominados como defeitos. Sua eliminação por completo é praticamente impossível, desta maneira é previsto na especificação condições de aceitação para estes defeitos. A seguir são apresentados alguns defeitos de fabricação do combustível.

O dog boning é o espessamento do núcleo do combustível nas extremidades devido ao arraste de partícula combustível durante a laminação. A diferença entre as propriedades mecânicas do material do núcleo e da moldura e revestimentos é o que proporciona tal concentração de material. Ao aumentar a espessura do núcleo, a consequência é a diminuição da espessura do revestimento, assim a especificação do combustível prevê um limite de espessura de revestimento nas extremidades menor do que a do interior do núcleo [2].

Outro defeito que ocorre também na extremidade do núcleo é conhecido como zona difusa. Este fenômeno acontece especialmente quando há diferença entre a espessura do briquete e da moldura. Quando a espessura do briquete é maior que a da moldura, o material físsil irá escoar por entre a moldura e o revestimento formando a zona difusa. Da mesma maneira que o defeito do dog boning, a especificação do combustível determina um arraste mínimo aceitável nesta zona difusa [2].

Na figura 3.5 é apresentado um desenho esquemático do dog boning e da zona difusa. 
Figura 3.5 - Defeito dog boning e zona difusa na extremidade do núcleo da placa combustível

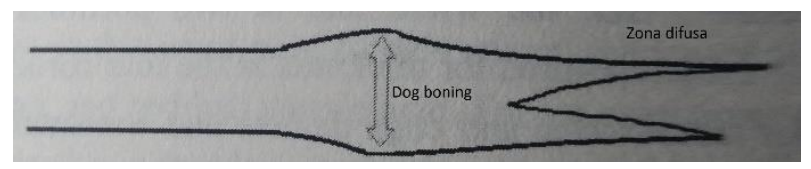

Fonte: [2] adaptada pelo autor

Ainda na etapa de laminação a quente, é previsto o caldeamento do conjunto briquete, moldura e revestimentos. Ao contrário dos outros defeitos, em que é aceitável suas ocorrências em determinado grau, o não caldeamento em qualquer parte que seja do conjunto não é aceitável. A literatura estima que 6 passes de laminação a quente são suficientes para que ocorra a total junção do conjunto, entretanto, presença de poros em excesso, ou altas cargas de material combustível podem comprometer o processo [2].

Os passes de laminação são cuidadosamente processados para evitar a curvatura excessiva da placa, entretanto é possível obter graus de curvaturas elevados, assim como o arqueamento do núcleo no interior da placa. Este último é conhecido como flecha, e é especificado um desvio mínimo entre a distância das laterais do núcleo com as laterais da placa aceitável para este defeito.

Além de não permitir o caldeamento, uma alta concentração de poros no núcleo do combustível e presença de trincas afetam a estabilidade mecânica da placa combustível.

A heterogeneidade da distribuição de material físsil na dispersão pode provocar zonas com uma densidade de urânio elevada, gerando zonas de calor no combustível comprometendo a segurança do reator. Tal defeito, pode ser visto através das imagens radiográficas do núcleo da placa com diferenças nas tonalidades de cinzas, indicando ausência de material combustível em manchas brancas no núcleo e excesso para tons mais escuros.

\subsection{Produção de pó da liga U-Mo}

$\mathrm{Na}$ área de metalurgia do pó, muitas são as técnicas para fabricação de pós. A escolha da técnica utilizada é dependente das características finais desejadas do material particulado. Na área do combustível nuclear, há uma série de técnicas que vem sendo estudadas para a produção de pós através das ligas de U-Mo. Cada uma destas técnicas resulta em partículas de material físsil com similaridades e diferenças entre si. 
Especificações para os parâmetros de morfologia e granulometria do pó são baseadas em considerações teóricas relacionadas a dispersões ideais quando submetidas a irradiação. O controle de alguns parâmetros durante a fabricação do material particulado de combustível permite a obtenção de uma melhor performance durante a queima [25].

Partículas com formas irregulares proporcionam maior atrito entre o material, que pode a vir dificultar a mistura com o pó de alumínio referente a matriz, por outro lado, partículas esféricas se misturam de forma mais homogênea, mas podem vir a causar segregação nas etapa de laminação da placa combustível. Ainda durante a etapa de laminação, pode ocorrer a fragmentação das partículas, o que pode ser minimizado com o aumento da densidade e com o grau de esfericidade do particulado [25, 26].

A distribuição granulométrica também é um importante aspecto a ser considerado. Para combustíveis nucleares do tipo dispersão é considerada uma faixa granulométrica aceitável entre 45 e $125 \mu \mathrm{m}$ [27] abaixo deste valor é considerado formação de pós finos que tendem a se aglomerar prejudicando a homogeneização, já partículas muito grandes tenderão se segregar por gravidade [5]. A faixa granulométrica deverá levar em conta o grau de fragmentação do particulado que ocorrerá durante o processo de fabricação do elemento combustível.

A seguir serão apresentados os fundamentos básicos e as principais vantagens e desvantagens das técnicas de moagem mecânica, atomização, eletroerosão, rotas químicas e hidretação-desidretação.

\subsubsection{Moagem mecânica}

A moagem mecânica é o método mais utilizado para a fabricação de pós metálicos e óxidos. É indicada para metais relativamente duros e quebradiços. No caso das ligas de U-Mo, que são relativamente dúcteis, o método apresenta certas desvantagens para o tamanho final da partícula, muito acima do desejado gerando altas taxas de rejeição, e quanto à forma devido ao alto índice de deformação do material. Outra grande desvantagem a respeito desta técnica é alta contaminação do particulado durante a moagem, irregularidade no tamanho das partículas e sua deformação microestrutural. Sua principal vantagem é a simplicidade e o custo de operação [28, 29, 30]. 


\subsubsection{Atomização}

A atomização é um método dominante de fabricação de pós de ligas metálicas. Trata-se, simplesmente, do processamento de um liquido em gotículas finas e sua posterior solidificação. Normalmente, o tamanho dos pós atomizados é menor que $150 \mu \mathrm{m}$. Sua morfologia é caracterizada pela esfericidade de suas partículas, são livres de porosidade e relativamente compactas com altas densidades de empacotamento e baixa área superficial. Para as ligas de U-Mo, a atomização centrífuga é a mais utilizada. [26]

Entretanto para a aplicação em combustíveis nucleares do tipo dispersão apresentam as seguintes desvantagens: faixa granulométrica próxima ao que seria considerado finos, alto custo de equipamentos, a forma esférica das partículas a alta compactação promove baixa porosidade na placa provocando inchamento durante a queima do combustível pelos produtos de fissão $[14,30]$.

\subsubsection{Eletroerosão e rotas químicas}

A eletroerosão é uma técnica utilizada para cortar e conformar materiais condutores através de descargas elétricas. Consiste em um feixe energético atingir uma área reduzida por uma fonte de energia pulsada, atingindo o ponto de fusão e ebulição da superfície atingida. Gotículas esféricas são ejetadas, e o metal liquido que permanece na superfície se solidifica, geralmente um uma forma esférica. Para as ligas U-Mo como combustível do tipo dispersão, as gotículas ejetadas são o material de interesse. Não há muitos estudos com esta técnica, entretanto foi possível se obter partículas esféricas numa faixa granulométrica de $10 \mu \mathrm{m}$ a $100 \mu \mathrm{m}$, com alta concentração de partículas finas [31].

Pós de U-Mo também são obtidos a partir de reação química com um metal redutor. Esta técnica apresenta as vantagens de pureza, controle da concentração de molibdênio nos grãos e controle da morfologia e porosidade. Entretanto, são fabricados pós na faixa de $10 \mu \mathrm{m}$, o que indica particulados muito finos para utilização em combustíveis nucleares [32, 33].

\subsubsection{Hidretação, moagem e desidretação}

Inicialmente, a hidretação de urânio metálico foi estudada para análise de corrosão do metal e posteriormente para a estocagem de trítio em instalações nucleares 
devido a sua alta taxa de absorção de hidrogênio. Atualmente, além de ser intermediário na formação de vários compostos de urânio, o hidreto de urânio é visto como um futuro combustível para reatores nucleares modulares [34, 35].

A hidretação-desidretação é baseada na reação do componente metálico com hidrogênio. Sendo uma reação reversível, o hidrogênio pode ser removido simplesmente aquecendo o pó num ambiente à vácuo. A técnica de hidretação de ligas U-Mo apresenta duas vertentes: a hidretação seguida diretamente da desidretação (HDH) e a hidretação seguida de moagem mecânica e posterior desidretação (HMD). Também há uma variação da técnica HMD com a ordem das etapas invertidas, hidretando, desidretando e moendo por último. O estudo diz que após a desidretação ainda existe uma tensão residual no pó que permite a moagem do material $[26,35,36]$.

A primeira técnica utiliza o pó formado durante a própria fase de hidretação. A formação do hidreto ocorre na fase $\alpha$-U presente nos contornos de grãos o que proporciona a fragmentação do material, devido à diferença de volume entre o metal e o hidreto formado. Na sequência, é realizada a desidretação que trata da retirada do hidrogênio na estrutura do metal normalmente a altas temperaturas e vácuo. A técnica HDH apresenta a desvantagem de um controle rigoroso na formação dos grãos e os resultados obtidos apresentaram pós muito finos abaixo da granulometria desejada. Estudos variam de 30 a $100 \%$ de pó fora da especificação com esta técnica. A segunda linha desenvolvida a partir da hidretação, aproveita a fragilização da liga de U-Mo com hidrogênio e incorpora uma moagem mecânica entre as fases de hidretação e desidretação. Possui um custo menor que a técnica de atomização e é possível obter mais de $50 \%$ do pó na faixa granulométrica adequada. Entretanto, durante a moagem pode ocorrer contaminação do pó, assim como oxidação do mesmo [16, 29, 37, 38].

As etapas de hidretação, moagem e desidretação são detalhadas a seguir.

\subsubsection{Hidretação}

A hidretação refere-se a incorporação do hidrogênio presente na atmosfera no metal e a consequente formação do hidreto.

Inicialmente, ocorre o processo de indução que consiste na interação do hidrogênio pelo metal através da adsorção física e química. Primeiro ocorre a fississorção da molécula de $\mathrm{H}_{2}$ e em seguida a quimissorção, onde ocorre a dissociação da molécula 
gerando hidrogênio na forma protônica. Este hidrogênio $\mathrm{H}^{+}$irá ser absorvido na superfície e posteriormente difundido pelo metal [26].

A indução ou ativação é uma das partes mais difíceis de serem controladas devido à variedade dos fatores que influenciam a interação do hidrogênio com a superfície do metal [27, 39]. Oxidação na superfície do material, irregularidade da superfície (defeitos, topografia, etc.) e impurezas presentes no gás e na superfície são exemplo destes fatores [35]. Camadas superficiais de óxido no metal agem como uma barreira à difusão do hidrogênio [39], entretanto submeter o material a ciclos térmicos para danificar estas camadas facilitam o início da hidretação, acelerando o processo de nucleação [40]. Tratamentos térmicos e técnicas de polimento e limpeza química também são estudados para ativação do material [41, 42].

Após a fase de adsorção da superfície do material, o hidrogênio tende a se acumular em diversos locais da microestrutura, como contornos de grãos, interstícios, discordâncias ou mesmo como uma solução sólida até que se atinja o seu limite de solubilidade e dê início à reação de hidretação. Quando a pressão do gás é elevada, um número limitado de átomos de hidrogênio é forçado para dentro da rede cristalina. Em uma determinada pressão e concentração crítica, o metal ficará saturado de hidrogênio e se transformará em uma nova fase: o hidreto metálico [26].

A reação entre o hidrogênio absorvido e o metal $(\mathrm{M})$ pode ser representada pela equação (2).

$$
M+2 H \quad \leftrightarrow M H_{2}
$$

A reação ocorre em uma faixa de temperatura entre 50 a $190{ }^{\circ} \mathrm{C}$ sobre a pressão de 1 bar [43]. Estudos variam o aquecimento nas câmaras de hidretação para sistemas UMo entre $120{ }^{\circ} \mathrm{C}$ a $700{ }^{\circ} \mathrm{C}$ com diferentes pressões entre 1 a 6 bar buscando melhorar a eficiência da reação. O tempo de indução também é uma variável entre os estudos, chegando a oscilar entre 1 a 4 horas. O início do processo com temperaturas mais elevadas se deve à ativação do metal. A reação, por ser exotérmica, tem uma taxa de absorção de hidrogênio maior durante o resfriamento do sistema [25, 27, 34, 37, 38, 43, 44, 45, 46, 47, 48, 49].

Para se obter o pó na granulometria desejada, também é estudado variar o número de ciclos de hidretação antes da moagem. Foi observado que quanto maior o número de ciclos consecutivos, maior a quantidade de hidrogênio absorvido por grama de metal. 
Estudos mostram a absorção máxima de hidrogênio sendo atingida entre 8 a 10 ciclos [48, 49]. A fragmentação do metal durante a hidretação proporciona maior área superficial para um próximo ciclo, o que explica o aumento do volume de gás absorvido em processos com vários ciclos de hidretação [46]. A fragmentação do metal ocorre devido à diferença dos volumes inicial do material e do hidreto, em uma concentração com $7 \%$ de átomos de Mo há uma diferença de densidade de $17,5 \mathrm{~g} \mathrm{~cm}^{-3}$ para $10,39 \mathrm{~g} \mathrm{~cm}^{-3}$ [43].

Adicionalmente, quanto maior o número de ciclos de hidretação, mais homogênea é a distribuição granulométrica, porém a faixa granulométrica em que se encontra o pó é mais baixa $[38,48]$.

\subsubsection{Moagem}

Após a hidretação, por questões de segurança, a câmara é submetida a vácuo para a retirada de possíveis moléculas de $\mathrm{H}_{2}$ ainda aprisionadas na estrutura cristalina a fim de se evitar uma atmosfera explosiva durante a etapa de moagem.

Em níveis de escala laboratorial, a moagem pode ser feita manualmente com um almofariz e pistilo. Em escalas maiores, se recomenda moinhos de baixo impacto de modo a evitar grande formação de finos [27, 44, 49].

Outra característica importante para o combustível tipo dispersão é a forma das partículas. Partículas provenientes da técnica HMD se apresentaram de forma lamelar, e mais regular do que as partículas provenientes de uma moagem mecânica tradicional. A própria fragmentação durante a hidretação do material promove faces planas no pó o que favorece a próxima etapa de fabricação do combustível, diminuindo a segregação das partículas durante a laminação [36, 44, 45, 46].

\subsubsection{Desidretação}

Embora a moagem defina bem as características do pó, ainda existe uma última fase de desidretação. Uma diminuição na distribuição granulométrica é observada após a desidretação devido à diferença entre as densidades do hidreto e da liga U-Mo, reduzindo em mais de $15 \%$ a dimensão das partículas [27].

A desidretação é a etapa final do processo e consiste na decomposição do hidreto e retirada do hidrogênio no sistema. Sendo a reação de hidretação reversível e 
exotérmica, com o aumento da temperatura no sistema, o equilíbrio é deslocado no sentido inverso da reação, o hidreto é decomposto e a liga retorna a sua composição inicial.

O procedimento consiste em retornar o material para a câmara onde foi hidretado e submeter a amostra a temperaturas elevadas e a baixíssimas pressões e/ou vácuo. As condições de hidretação também variam entre os estudos, especialmente em relação a temperatura e tempo do processo. Temperaturas vão de 300 a $700{ }^{\circ} \mathrm{C}$ nesta etapa com o duração entre 1 a 5 horas [27, 36, 37, 38, 43, 45, 47, 48]. Para liberação de hidrogênio em concentrações da ordem de $50 \mathrm{ppm}$, é sugerido aquecimento a $700{ }^{\circ} \mathrm{C}$ por pelo menos 2 horas sob vácuo. Estudos que detalham a etapa de desidretação preveem um processo de no mínimo 5 horas [46].

Após esta etapa é importante garantir a presença da fase $\gamma \mathrm{U}$. Além disso, recomenda-se manter o material sob uma atmosfera inerte para evitar a oxidação do pó formado. 


\section{MATERIAIS E MÉTODOS}

\subsection{Materiais}

4.1.1. Urânio

O urânio metálico utilizado foi produzido pelo CCN-IPEN conforme descrito no item 3.2.1. Para a confecção das placas combustíveis foi utilizado urânio natural, com concentração isotópica de $0,711 \%$.

O metal foi cortado a partir de um tarugo, cuja massa limite foi definida pelo volume da lingoteira a ser utilizada no forno de indução. A massa de urânio utilizada para a fusão foi de $611,70 \mathrm{~g}$.

\subsubsection{Molibdênio}

O molibdênio utilizado é de origem da empresa Alfa Aesar com 99.95\% de pureza. O metal é encontrado em pequenos cilindros com dimensões de 3,175 $\mathrm{mm}$ de diâmetro e 6,35 mm de comprimento, com cerca de $0,51 \mathrm{~g} /$ cilindro.

A massa de molibdênio pesada foi a equivalente a proporcionar a concentração de $7 \%$ na liga metálica com base na massa de urânio.

4.1.3. Pó de alumínio para matriz na dispersão

O alumínio utilizado como matriz na dispersão é um pó lamelar de origem da empresa Sigma Aldrich com especificação A7-11067, pureza de 99,58 \pm 0,01\% e partículas menores que $45 \mu \mathrm{m}$.

4.1.4. Chapas de alumínio para moldura e revestimento

O alumínio para revestimento são placas extrudadas de origem da empresa ALCOA especificadas segundo norma ASTM B308/B308M-10 "Standard Specification for Aluminum-Alloy 6061-T6 Standard Structural Profiles". 


\subsection{Fusão da liga U-Mo}

A fusão da liga foi realizada no forno de indução eletromagnética modelo Indutherm VTC200VTi.

O urânio metálico foi previamente cortado em cilindros e pesados em uma balança com precisão de duas casas decimais. O molibdênio estava em forma de pequenos cilindros e após montagem, os metais foram carregados em um cadinho de zircônia. O molibdênio foi colocado ao fundo do cadinho e o tarugo de urânio metálico previamente decapado com ácido nítrico $65 \%$ foi posicionado acima. Foi fundida uma massa de 611,70 g de U com 45,76 g de Mo, totalizando uma massa de 657,74 g de material.

$\mathrm{O}$ sistema foi submetido a um vácuo mecânico $510^{-2}$ mbar previamente à indução para retirada de impurezas na atmosfera do forno e inertizado em atmosfera de argônio com pureza 99,999\%, após esta etapa o forno foi aquecido a $1800{ }^{\circ} \mathrm{C}$ por cerca de 10 minutos para homogeneização da liga. A temperatura de vazamento foi próxima do valor máximo e o tempo mínimo para retirada da peça da lingoteira após a fusão foi de 4 horas. Para a conformação do lingote, foi utilizada uma lingoteira retangular de dimensões $150 \mathrm{~mm}$ x $64 \mathrm{~mm}$ x $4 \mathrm{~mm}$. A figura 4.1 apresenta uma imagem do forno de indução (a), interior do forno com cadinho e lingoteira (b) e detalhe da lingoteira (c).

Figura 4.1 - Imagens do forno de indução (a), interior forno (b) e lingoteira (c)
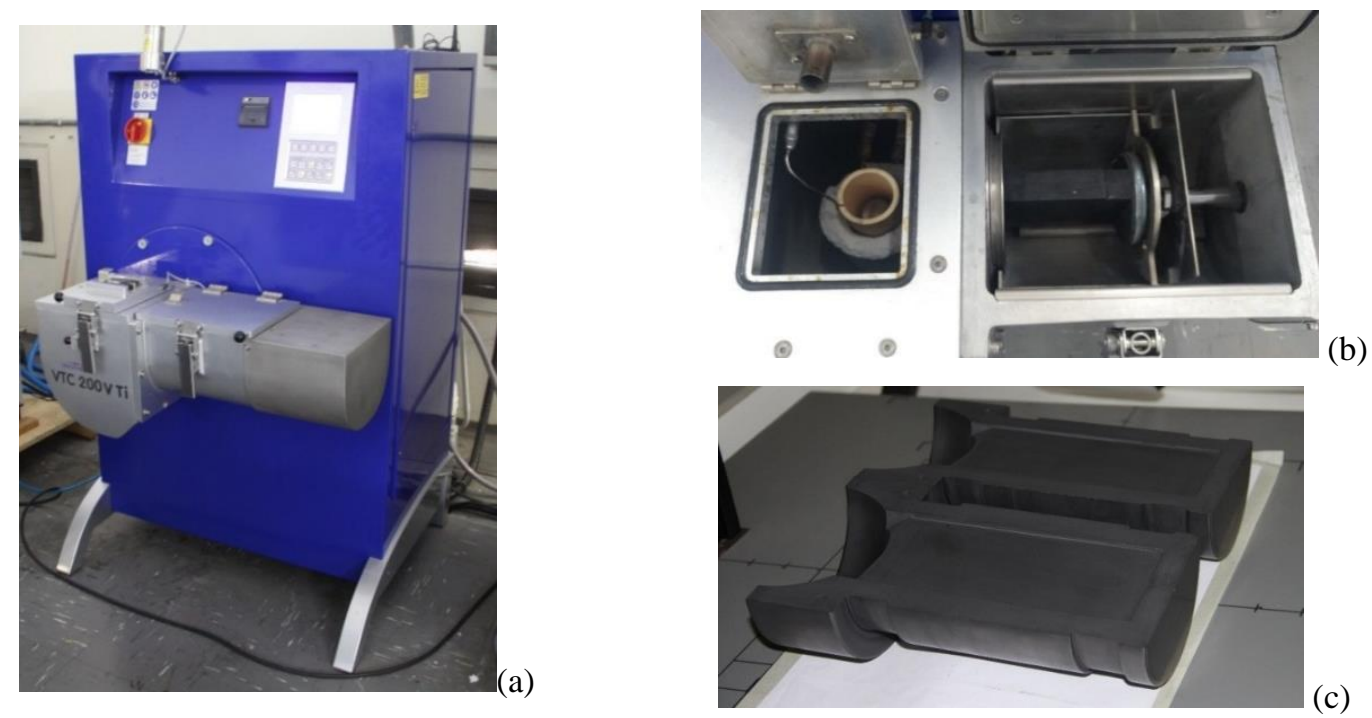

Fonte: autor 
A liga foi caracterizada pelas seguintes técnicas: difração de raios $\mathrm{X}$, microscopia óptica e microscopia eletrônica de varredura.

\subsection{Fabricação do pó de U7Mo}

\subsubsection{Corte do lingote}

Para a hidretação, o lingote obtido foi cortado transversalmente em 5 peças com massa aproximada de $100 \mathrm{~g}$ cada. Foi utilizado o equipamento Techcut 5 da empresa Allied com um disco de carbeto de silício de espessura $0,76 \mathrm{~mm}$ com rotação de 2.800 rpm e água corrente para refrigeração durante o corte.

\subsubsection{Decapagem}

Antes de serem hidretadas, as peças foram submetidas ao processo de decapagem química para retirada de óxidos superficiais conforme o procedimento adotado pelo $\mathrm{CCN}$ e apresentado na figura 4.2.

Figura 4.2 - $\quad$ Procedimento de decapagem para U7Mo

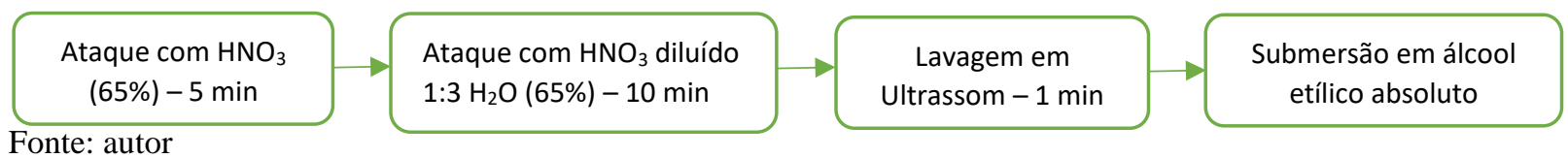

A retirada das peças do álcool etílico foi realizada em caixa de luvas com atmosfera inerte de argônio.

\subsubsection{Hidretação}

A hidretação ocorreu em um sistema desenvolvido pelo CCN constituído de uma retorta acoplada à caixa de luvas, um forno tubular resistivo da marca GRION com controlador Novus N1200HC, um sistema de injeção de argônio e de hidrogênio, uma bomba de vácuo e um sistema de aquisição de dados fornecido pela empresa Lynx Tecnologia Eletrônica Ltda. A caixa de luvas é mantida inertizada com gás argônio para manuseio do pó hidretado com segurança e para minimizar a oxidação das partículas de U7Mo, mantendose uma pressão positiva em relação a atmosfera externa. 
A caixa de luvas possui uma anti câmara por onde o material é inserido. A porta externa é aberta e o material posicionado na câmara. Ao fechar o acesso, é feito um vácuo para retirada do ar ambiente e em seguida injeta-se argônio para equalizar a pressão com entre os compartimentos. A porta da anti câmara com acesso interno é então aberta e o material é retirado no interior da caixa de luvas em atmosfera inerte.

As peças já no interior da caixa de luvas foram pesadas e colocadas dentro de um cadinho de alumina que, em seguida, foi inserido na retorta. $O$ forno tubular foi posicionado ao redor da retorta. Foi realizada uma purga alternando vácuo de 5,0 $10^{-2} \mathrm{mbar}$ com injeção de argônio.

O sistema foi pressurizado com 2 bar de hidrogênio com pureza de 99,9992\% e aquecido até $700{ }^{\circ} \mathrm{C}$ a uma taxa de aquecimento $15{ }^{\circ} \mathrm{C} \min ^{-1}$. Após 1 hora no patamar a $700{ }^{\circ} \mathrm{C}$, a retorta foi retirada do forno e resfriada até temperatura ambiente. O cadinho com as peças hidretadas continuaram sobre atmosfera de hidrogênio a 2 bar por mais 16 horas.

A figura 4.3 mostra foto da caixa de luvas (a) e o detalhe do cadinho no interior da retorta (b).

Figura 4.3 - Caixa de luvas (a), detalhe da retorta e cadinho (b)

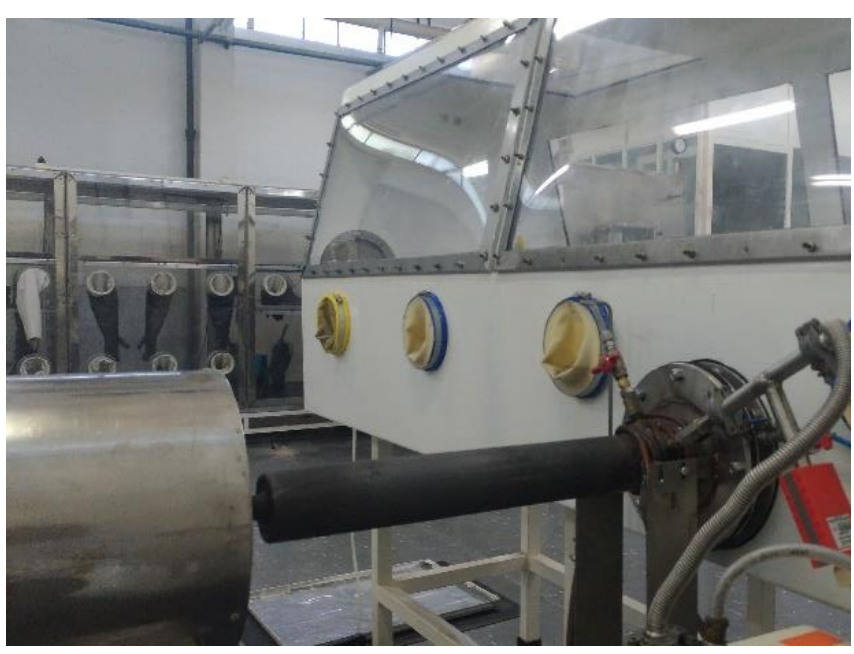

(a)

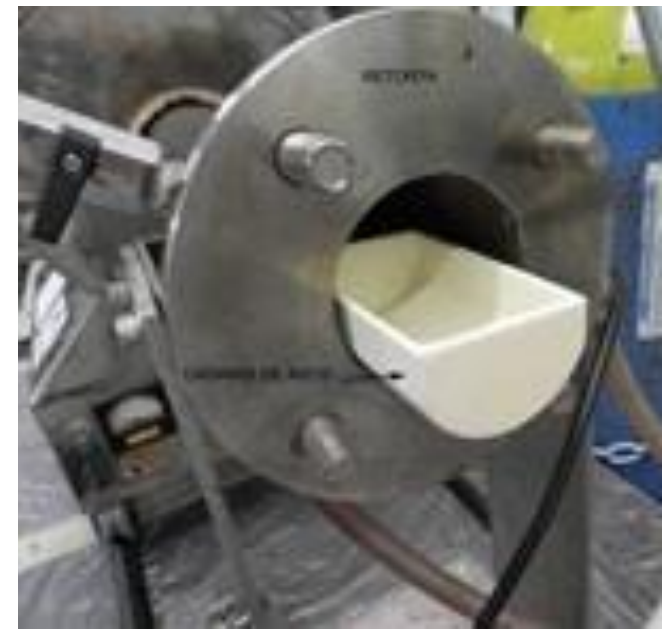

(b)

Fonte: autor

\subsubsection{Moagem}

Após o resfriamento, foi feito vácuo até 5,0 $10^{-2} \mathrm{mbar}$ para retirada do hidrogênio do sistema. A retorta foi preenchida com Ar para ser aberta dentro da caixa de luvas. O 
cadinho foi retirado da retorta e o conteúdo peneirado manualmente para separação do pó cuja dimensão já se encontrava abaixo de $125 \mu \mathrm{m}$ após a hidretação. O restante do material foi moído manualmente utilizando-se um almofariz e pistilo de ferro, apresentado na figura 4.4, e peneirado novamente.

Figura 4.4 - Almofariz e pistilo de ferro utilizado na moagem

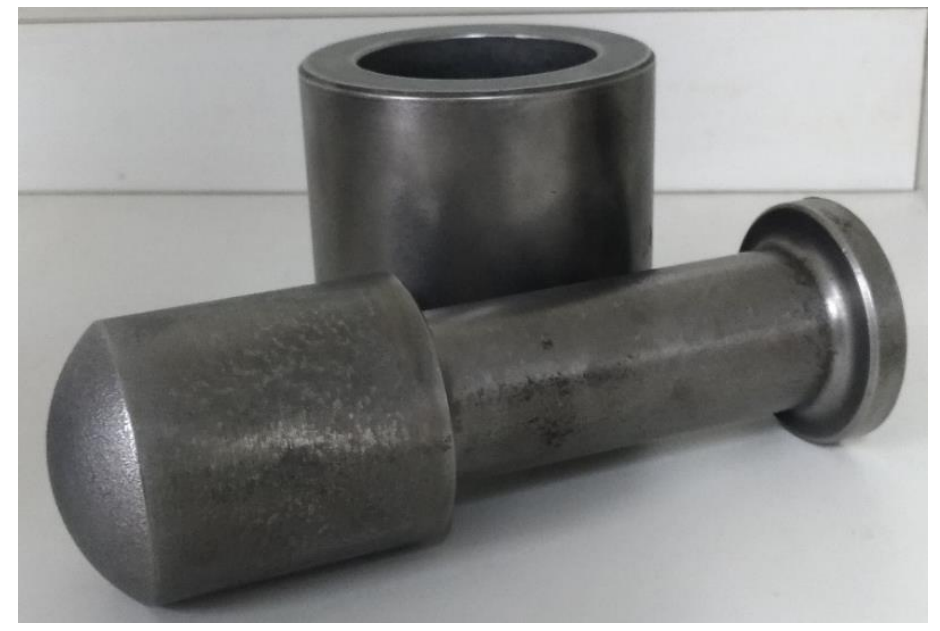

Fonte: autor

Durante o peneiramento se trabalhou com duas faixas granulométricas, denominadas FGD (faixa granulométrica desejada) e FGF (faixa granulométrica com finos). A FGD para o pó foi especificada de 44 a $125 \mu \mathrm{m}$ e para os finos $<44 \mu \mathrm{m}$. Foram utilizadas peneiras de 325 e 115 mesh para separação do particulado. Ao fim deste processo, a massa da amostra que estava acima da FGD retornou para a retorta para a realização de um novo ciclo de hidretação. Os ciclos de hidretação foram realizados até total cominuição do material, ou seja, até que não restasse massa acima da FGD.

\subsubsection{Desidretação}

Após obtenção da quantidade de pó necessária para as próximas etapas, o pó hidretado foi submetido ao processo de desidretação.

O sistema foi submetido ao vácuo de $5,010^{-2} \mathrm{mbar}$ e aquecido até $700{ }^{\circ} \mathrm{C}$ a uma taxa de aquecimento de $5{ }^{\circ} \mathrm{C} \mathrm{min}^{-1}$. Ao atingir a temperatura, o sistema foi resfriado até a temperatura ambiente. A retorta foi aberta e o pó final foi peneirado novamente devido à diferença de volume entre a partícula hidretada e a desidretada. 
O pó hidretado e o pó final foram caracterizados utilizando-se difração de raios $\mathrm{X}$, microscopia eletrônica de varredura e picnometria de hélio, esta última para determinação da massa específica do pó final apenas.

\subsection{Fabricação dos briquetes}

Os briquetes U7Mo-Al foram preparados segundo os procedimentos tradicionais adotados pelo Centro do Combustível Nuclear do IPEN, apenas adequando-se às propriedades mecânicas da liga [23].

Os briquetes foram dimensionados com base em uma placa combustível para o reator RMB: 3,8 mm de espessura, 89,67 mm de comprimento e 62,62 $\mathrm{mm}$ de largura. Com estas dimensões, obteve-se um volume de $21,04 \mathrm{~cm}^{3}$ na matriz da prensa.

Foram especificadas 2 placas: uma com a densidade de $4 \mathrm{gU} \mathrm{cm}^{-3} \mathrm{e}$ outra com o máximo de $45 \%$ da liga de urânio em volume no briquete, totalizando $7 \mathrm{gU} \mathrm{cm}^{-3}$. Para a placa com densidade de urânio de $4 \mathrm{gU} \mathrm{cm}^{-3}$, foi calculada uma massa de 84,16 g de U, equivalente a 90,49 g de U7Mo. A partir da densidade específica do pó no valor de 16,63 g $\mathrm{cm}^{-3}$ foi possível calcular o volume de U7Mo da liga no valor de $5,44 \mathrm{~cm}^{3}$. A diferença entre os volumes calculados do briquete e de U7Mo forneceu o volume de alumínio e sua respectiva massa considerando $5 \%$ de porosidade no briquete. A massa de alumínio obtida foi de 34,42 g. Por fim, ao somar as massas de U7Mo e Al, tem-se a massa total do briquete no valor de $129,91 \mathrm{~g}$.

Para o segundo briquete, foi previsto $45 \%$ em volume de U7Mo. Este valor considera $5 \%$ em porosidade e $50 \%$ do volume da matriz de Al, valor máximo em volume da liga para evitar danos estruturais e descontinuidade da matriz. Obtida a massa de 157,44 g de U7Mo, a massa de Al foi calculada de forma análoga à anterior, fornecendo um valor de 28,51 g, totalizando uma massa de 185,94 g para o briquete. A densidade de urânio nestas condições foi de aproximadamente $7 \mathrm{gU} \mathrm{cm}^{-3}$.

Os pós foram pesados separadamente em uma balança com precisão de $0,01 \mathrm{mg}$ dentro de uma caixa de luvas. O pó de U7Mo foi carregado primeiro, seguido do pó de Al em um recipiente com uma tampa selada. O recipiente foi acoplado a um equipamento rotativo e homogeneizado por 2 horas. 
Após a mistura, os pós foram cuidadosamente transferidos para uma matriz para a etapa de compactação do briquete. A cavidade da matriz foi alimentada manualmente, tomando-se cuidado para evitar a segregação do pó de U7Mo, o que ocorre devido à grande diferença de densidade dos pós de U7Mo e Al. A pressão de compactação foi de 5 ton/ $\mathrm{cm}^{2}$, atingida com carga de 280 toneladas na prensa. A prensa utilizada é de fabricação da empresa Farex modelo PHHT-4C-450/450T de duplo estágio com capacidade de 450 toneladas. A figura 4.5 mostra foto do equipamento rotativo (a), prensa (b) e em detalhe a matriz do briquete (c).

Figura 4.5 - Equipamento rotativo para mistura e homogeneização dos pós (a), prensa para compactação do briquete (b) detalhe matriz da prensa (c)

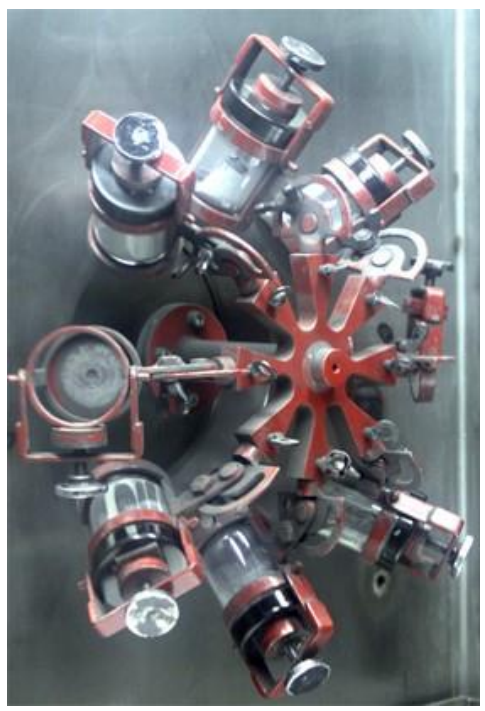

(a)

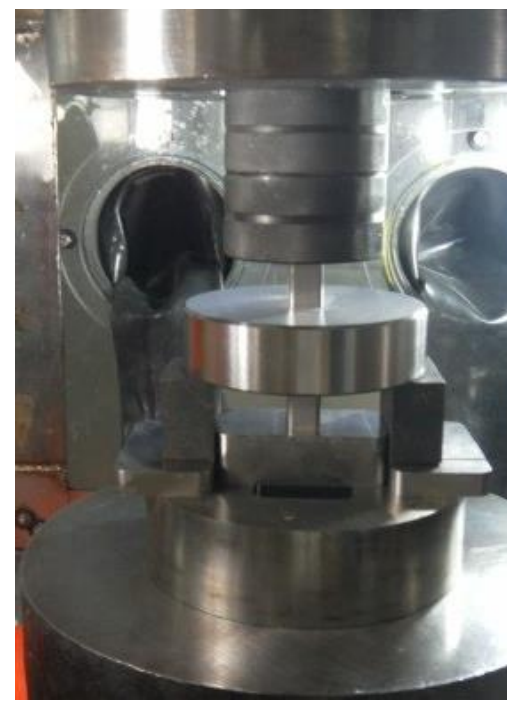

(b)

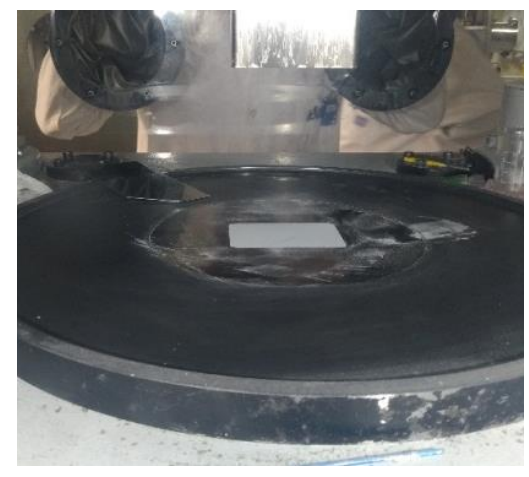

(c)

Fonte: autor

\subsection{Fabricação das placas combustíveis}

As placas combustíveis foram especificadas com as dimensões do combustível a ser utilizado no RMB e estão indicadas na tabela 4.1 
Tabela 4.1 - Especificação das dimensões das placas combustíveis

\begin{tabular}{c|c|c|c|c|c|c}
\hline \multirow{2}{*}{} & \multicolumn{2}{|c|}{$\begin{array}{c}\text { Comprimento } \\
(\mathrm{mm})\end{array}$} & \multicolumn{2}{c|}{$\begin{array}{c}\text { Largura } \\
(\mathrm{mm})\end{array}$} & \multicolumn{2}{c}{$\begin{array}{c}\text { Espessura } \\
(\mathrm{mm})\end{array}$} \\
\cline { 2 - 7 } & MIN & MAX & MIN & MAX & MIN & MAX \\
\hline Dimensões da placa & 654,80 & 655,20 & 74,85 & 75,15 & 1,33 & 1,37 \\
\hline Dimensões do núcleo & 611,50 & 618,50 & 64,00 & 66,00 & - & - \\
\hline Espessura revestimento & \multicolumn{4}{c}{ Extremidade } & 0,30 & - \\
\cline { 2 - 7 } & \multicolumn{4}{c|}{ Centro } & 0,33 & - \\
\hline
\end{tabular}

\subsubsection{Montagem e laminação das placas}

A técnica de fabricação foi a mesma utilizada na produção rotineira das placas combustíveis no CCN, utilizando a técnica de montagem núcleo-moldura-revestimentos (Picture Frame Technique).

As placas de revestimento e moldura passaram por um processo de decapagem em uma solução de $\mathrm{NaOH}$ a $10 \%$, seguida de lavagem em água corrente e neutralização em uma solução de $\mathrm{HNO}_{3}$ a 40\%. Esse tratamento superficial é necessário para a garantia do caldeamento entre os componentes do conjunto para a laminação.

Para a montagem do briquete na cavidade da moldura, a moldura foi previamente aquecida a $480^{\circ} \mathrm{C}$ por 5 minutos a fim de ocorrer dilatação para o encaixe do briquete. Dessa forma, os briquetes foram encaixados nas respectivas molduras por ajuste por interferência.

Os revestimentos e a moldura foram soldados nas laterais pelo processo TIG (do inglês: Tungsten Inert Gas). As bordas do conjunto não foram soldadas, permitindo saída de ar durante o processo de laminação. Antes do primeiro passe de laminação, o conjunto soldado foi aquecido a $440{ }^{\circ} \mathrm{C}$ por 1 hora em forno resistivo, seguindo-se a laminação a quente.

Foram realizados 8 passes de laminação a quente em cada placa, sendo que no intervalo de cada passagem o conjunto retornava ao forno a $440{ }^{\circ} \mathrm{C}$ por 15 minutos. Em cada passe as placas foram rotacionadas transversalmente e longitudinalmente a fim de minimizar os defeitos de fabricação. A figura 4.6 mostra o esquema de rotação para a laminação 
Figura 4.6 - Esquema de rotação entre os passes de laminação a quente

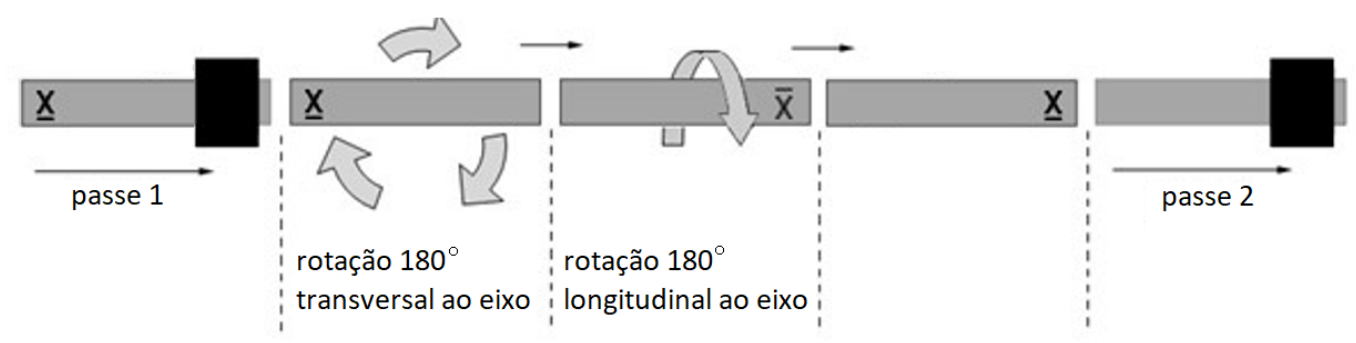

Fonte: [2] adaptada pelo autor

O laminador utilizado é equipamento de fabricação da empresa Stanat Albert Mann Engineering e é apresentado na figura 4.7.

Figura 4.7 - Foto do laminador utilizado para confecção das placas

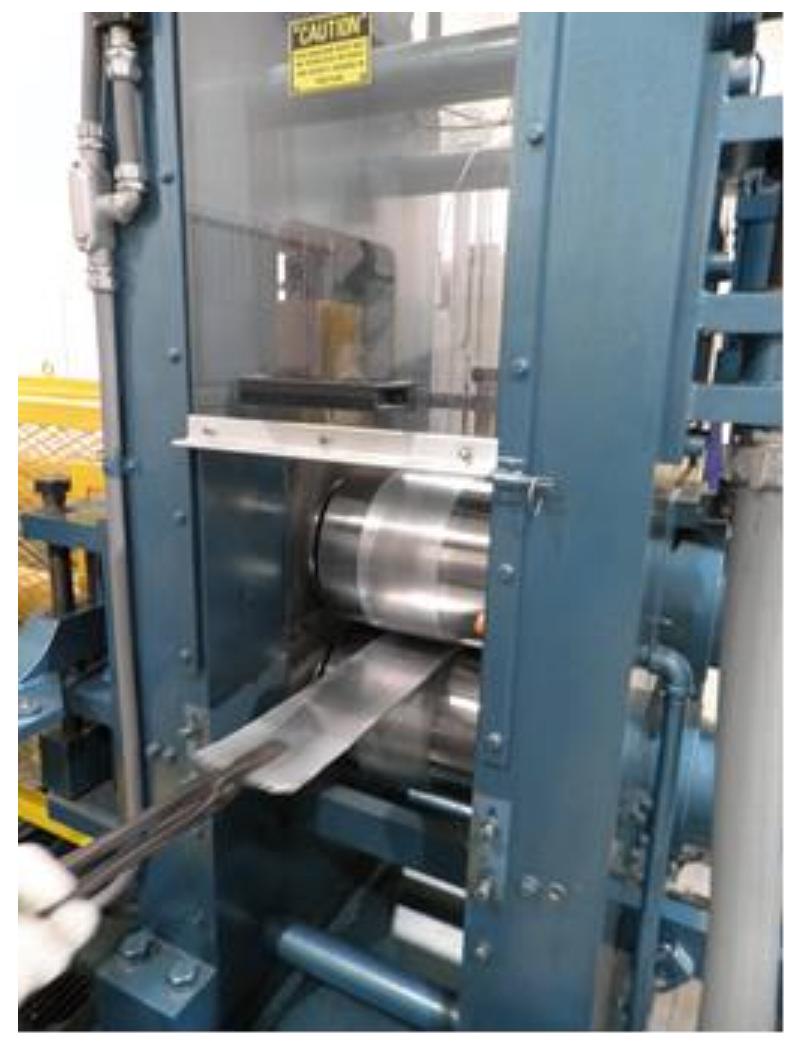

Fonte: autor

Findada a laminação a quente, foi realizado a inspeção visual para verificação da existência de bolhas. 
A laminação a frio para o ajuste da espessura especificada foi executada no mesmo laminador usado na laminação a quente. A laminação a frio é realizada com 2 passes à temperatura ambiente.

Após atingida a espessura na laminação a frio, a placa passa por um nivelador de rolos para retirar as ondulações na placa provenientes da laminação.

A figura 4.8 apresenta um esquema ilustrando a placa final, contendo o seu núcleo interno, isolado pelo revestimento e moldura de alumínio.

Figura 4.8 - Esquema da placa após laminação

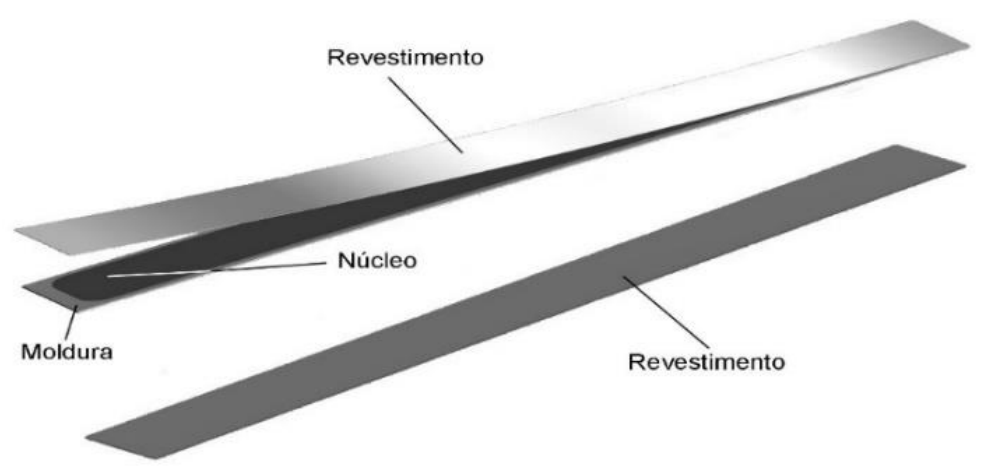

Fonte: [2]

Após a fabricação das placas, elas foram previamente radiografadas para localização do núcleo. O objetivo dessa radiografia é a realização da marcação para orientar o corte final e medição das dimensões do núcleo (largura e comprimento). Nessa etapa, outra radiografia é obtida, porém com a finalidade de se observar possíveis defeitos no núcleo, como trincas, partículas combustíveis fora do núcleo e homogeneidade na distribuição de urânio. Com base na marcação realizada na radiografia de localização, as placas foram cortadas numa guilhotina hidráulica. Após o corte final as placas foram novamente radiografadas para verificar a centralização do núcleo, conforme a especificação.

\subsubsection{Caracterização das placas}

As placas foram cortadas para análise metalográfica em cortadeira de precisão Isomet dotada de disco diamantado. As amostras foram embutidas em resina de cura a frio da marca Struers, lixadas mecanicamente em lixas d'água na sequência de \#320, \#400, \#600, 
\#800 polidas com pasta de diamante de $6 \mu \mathrm{m}$ e com solução aquosa de sílica coloidal de 0,2 $\mu \mathrm{m}$. Foram analisadas em 7 regiões para medição das espessuras do núcleo e dos revestimentos por meio de metalografia e observação em microscópio óptico e microscopio eletrônico de varredura conforme seções da figura 4.9.

Figura 4.9 - Desenho esquemático para metalografia

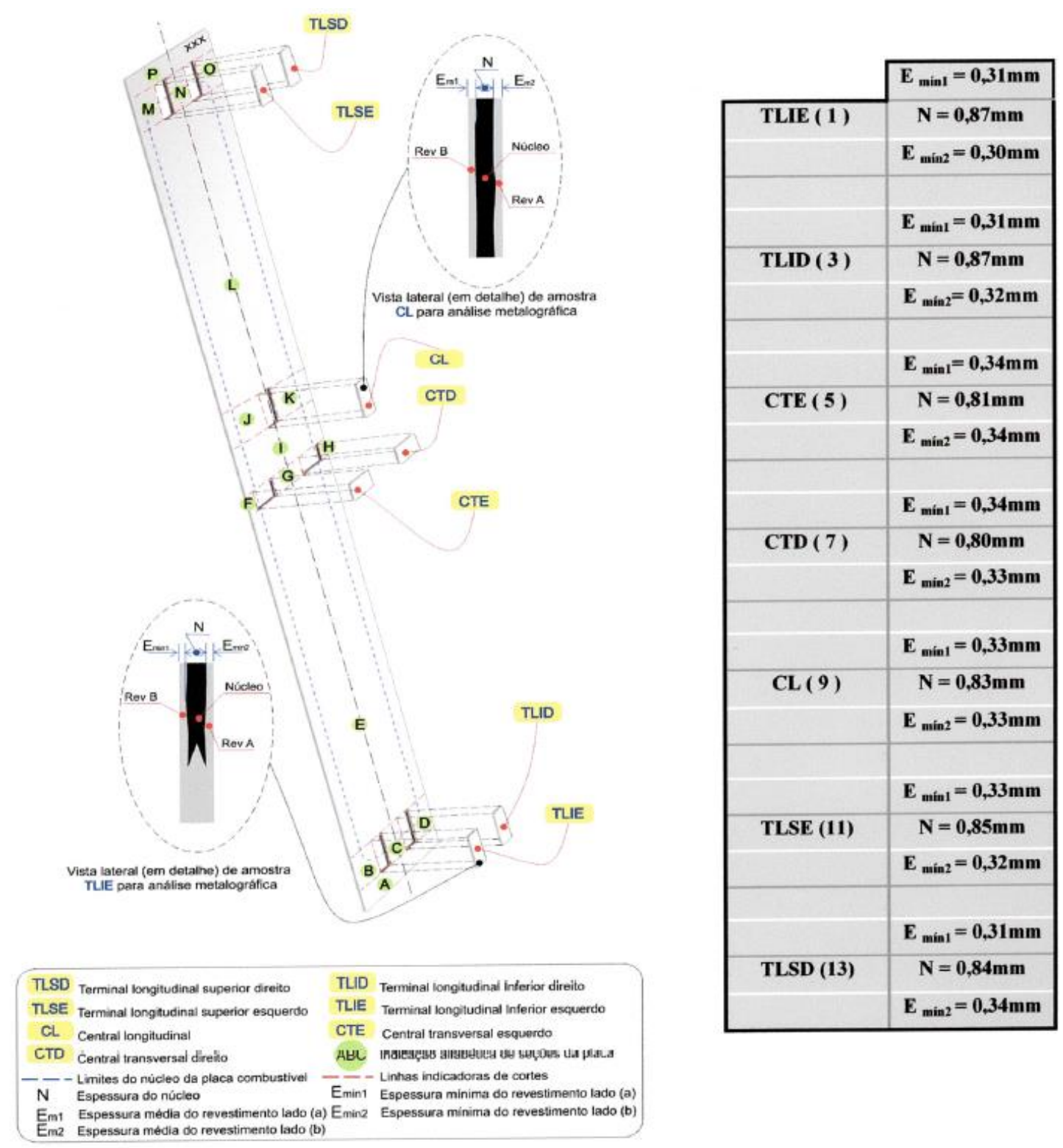

Fonte: Documentação de Qualificação - Seção 1 - Briquetes e Placas Combustíveis - DQ-CCN-097-00 


\subsection{Equipamentos para caracterização}

4.6.1. Difratômetro de raios X

O equipamento utilizado para análise das fases presentes no lingote e no pó final foi o difratômetro de raios X da marca Bruker modelo D8 Advance. As condições de análise foram medidas em $2 \theta$ de 10 a $90^{\circ}$ com tempo de 10 s por passo de $0,02^{\circ}$ com filtro $\mathrm{CuK} \alpha 1$.

\subsubsection{Microscópio óptico}

O microscópio óptico utilizado é de fabricação da empresa Carl Zeiss, modelo Axio Imager 2. As análises do lingote foram feitas com luz polarizada e as demais análises das placas foram realizadas com feixe em campo claro com aumentos de 20x e 5x, respectivamente.

\subsubsection{Microscópio eletrônico de varredura}

O microscópio eletrônico de varredura é da empresa Thermoscientific modelo Prisma E. As análises foram realizadas com feixes de elétrons retroespalhados e secundários, análise de espectroscopia de dispersão de energia. As condições de análise foram com $20 \mathrm{kV}$ para resolução do feixe e alto vácuo de $610^{-4} \mathrm{~Pa}$.

A técnica foi utilizada para caracterização da morfologia dos pós hidretados e desidretados, e também para análise do núcleo das placas combustíveis. As micrografias apresentadas utilizaram aumentos de 30 a 1000x.

\subsubsection{Picnômetro de hélio}

Para obtenção da densidade aparente do pó final foi utilizado o equipamento AccuPyc 1330 da empresa micromeritics. A análise foi realizada nas seguintes condições: 30 purgas, 30 repetições, 19,5 psig de pressão de preenchimento e temperatura de análise em $22{ }^{\circ} \mathrm{C}$.

\subsubsection{Radiografia das placas}

As placas foram radiografadas em equipamento da empresa COMET com tubos de raios X modelo MXR-160/21 com comando eletrônico por microprocessador MP1. As condições de exposição para essa radiografia foram $70 \mathrm{kV}, 14 \mathrm{~mA}$, por 3,5 minutos. As 
imagens foram obtidas por sistema com câmera digital de varredura de raios X modelo SEZ T3-160 e analisadas em software iX-Pect da empresa NTB XRAY.

\subsubsection{Espectroscopia dispersiva de raios $\mathrm{X}$}

A análise EDX foi realizada a feixe de marca ThermoFischer Scientific acoplada ao microscópio descrito no item 4.6.3. Utilizou-se o software Pathfinder ${ }^{\mathrm{TM}} \mathrm{X}$-ray Microanalysis. As condições de análise foram as mesmas para a obtenção das imagens de MEV. A técnica foi utilizada para caracterização elementar no lingote e no núcleo do combustível.

\subsubsection{Análise de imagem}

A análise de imagem foi realizada através do software OmniMet ${ }^{\mathrm{TM}}$ da empresa Buehler para verificação da fração volumétrica nos núcleos dos combustíveis. As imagens obtidas por MEV foram tratadas de maneira em que o contraste entre partículas combustíveis e matriz permitisse a obtenção da porcentagem superficial de cada fase na imagem. 


\section{RESULTADOS E DISCUSSÃO}

\subsection{Liga U7Mo}

O lingote fundido de U7Mo foi cortado transversalmente em 5 peças com massas de 115,33 g, 100,34 g, 123,89 g, 118,36 g e 124,03 g. A perda medida durante o corte foi de 22,02 g. O lingote foi caracterizado pelas técnicas de difração de raios X, microscopia óptica e microscopia eletrônica de varredura.

Para verificação da conversão do $\alpha U$ para $\gamma U$ na fusão do lingote foi realizado a análise por difração de raios $\mathrm{X}$ da peça, apresentada na figura 5.1.

Figura 5.1 - Difratograma de raios X do lingote de U7Mo bruto de fusão

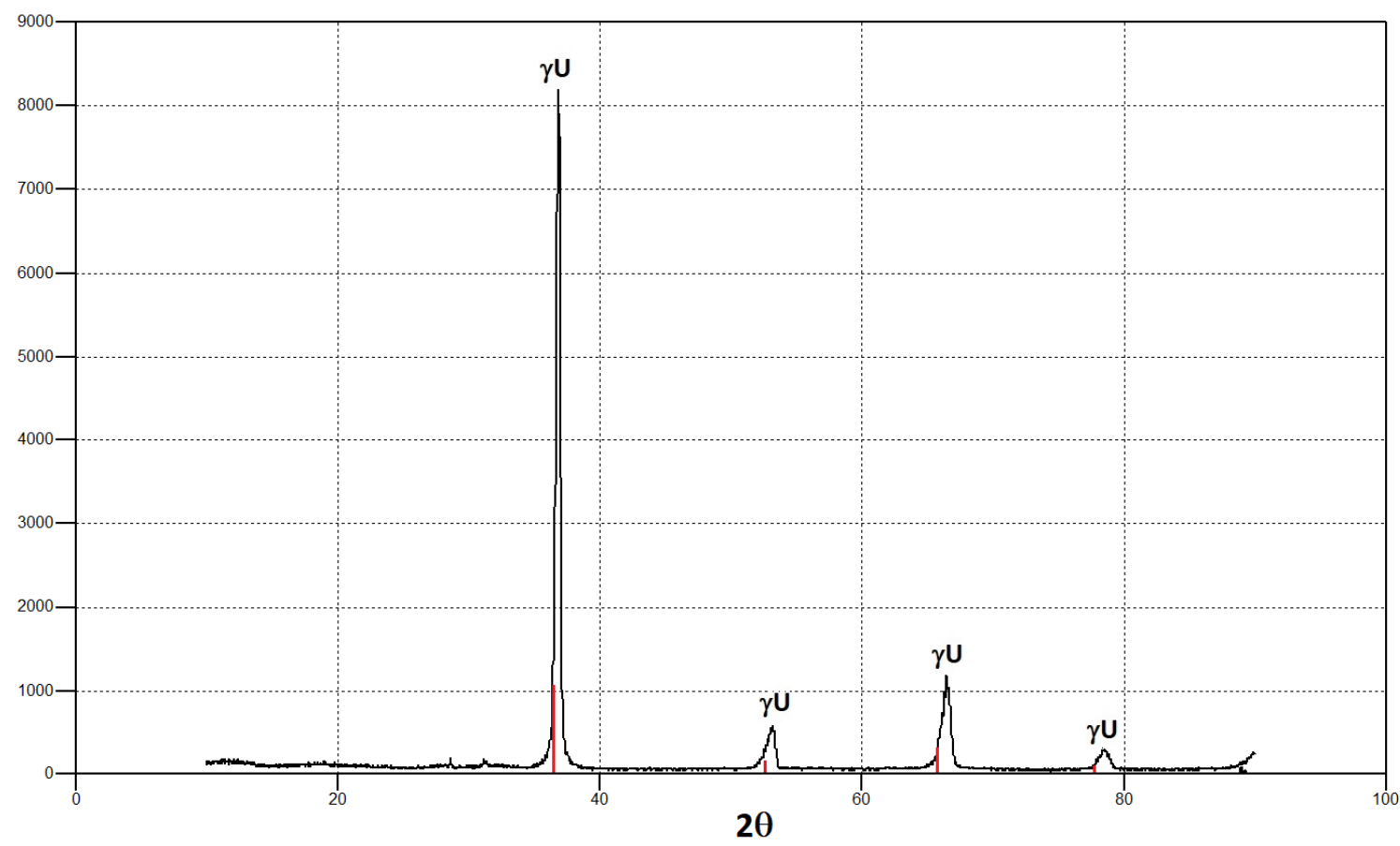

Fonte: autor

Observa-se da figura 5.1, que os picos referentes ao urânio foram todos convertidos para fase $\gamma$ conforme indicado na figura, não se detectando nenhum pico 
referente a urânio $\alpha$. Os picos referentes ao $\gamma U$ são deslocados levemente para a direita quando comparada ao $\gamma \mathrm{U}$ puro devido a presença de Mo na estrutura cristalina. Os traços em vermelho na figura apresentam os picos da fase $\gamma U$ provenientes da ficha de difração 24749.

Nota-se a presença de 2 picos com baixa intensidade na região $2 \theta$ próxima a $30^{\circ}$, indicando a presença de óxidos e carbono para o primeiro e segundo pico, respectivamente.

Nass figuras 5.2 a e 5.2 b são apresentadas uma foto do lingote bruto de fusão e sua imagem da microestrutura após polimento em microscopia óptica, respectivamente.

Figura 5.2 - Lingote: foto do lingote bruto de fusão (a), micrografias ópticas em três partes ao longo da peça (b)

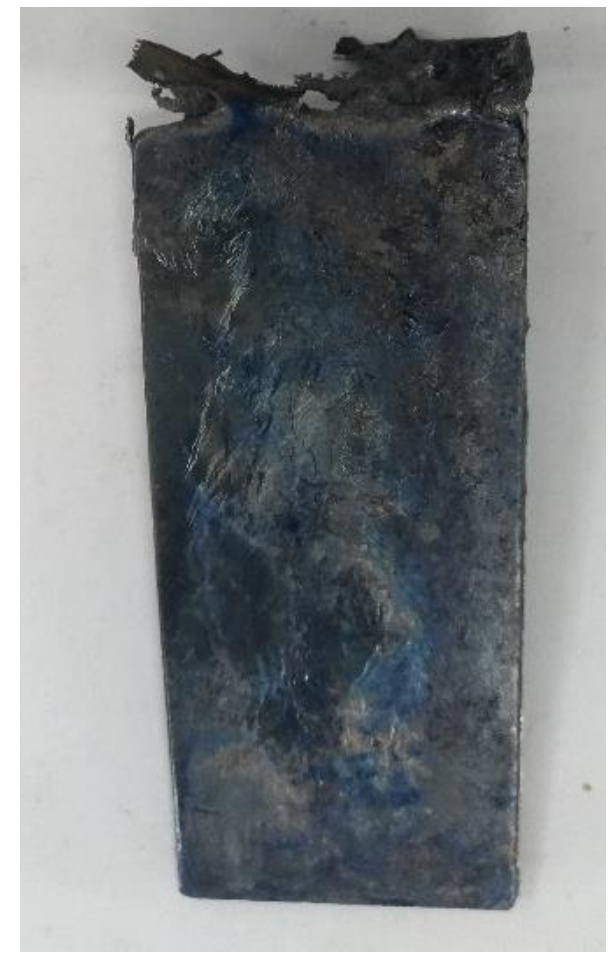

(a)

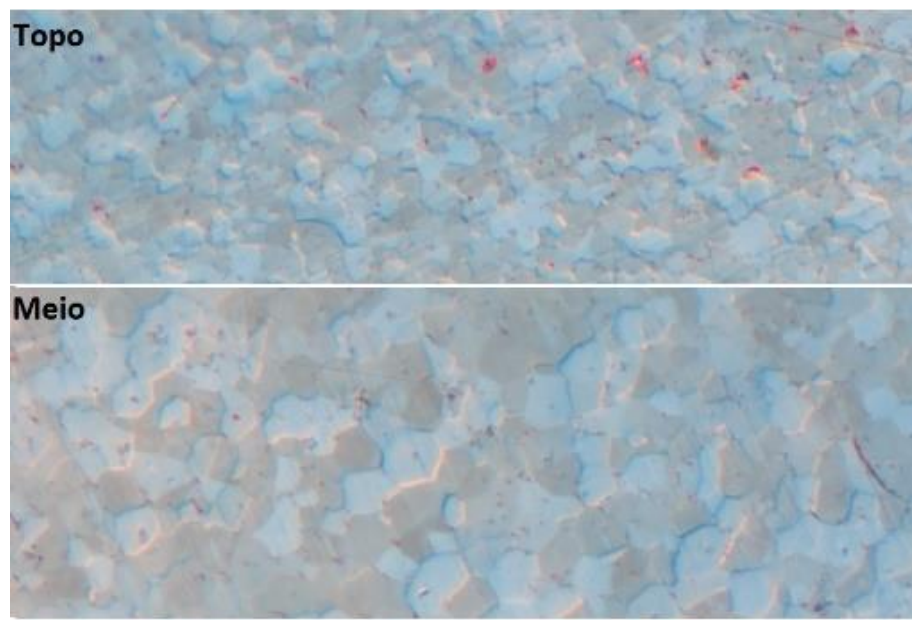

Fundo

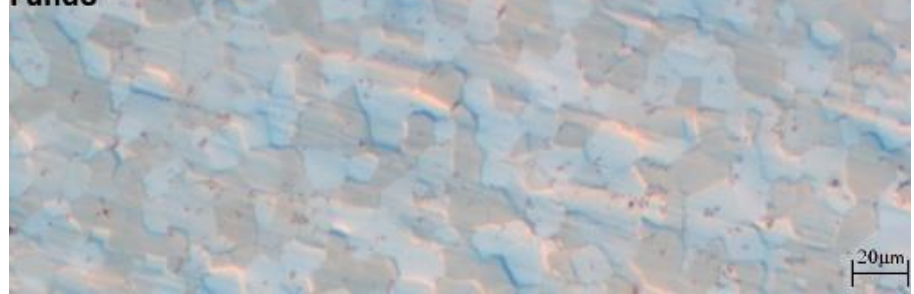

(b)

Fonte: autor

Observa-se claramente o contorno de grãos na faixa de $20 \mu \mathrm{m}$ no fundo e meio do lingote, sendo que, na proximidade ao topo da lingoteira, tem-se uma clara diminuição dos tamanhos de grãos. A diferença entre os tamanhos de grãos ao longo do lingote indicam que durante o vazamento da liga fundida a velocidade de solidificação não foi homogênea 
para a peça inteira. Os pontos avermelhados apresentados na imagem distribuídos pelo lingote foram analisados por microscopia eletrônica de varredura e espectroscopia por dispersão de energia. São mostradas na figura 5.3 a e 5.3 b imagens obtidas por microscopia eletrônica de varredura do lingote obtida por elétrons secundários e retroespalhados, respectivamente.

Figura 5.3 - Imagem de microscopia eletrônica de varredura da superfície do lingote por elétrons secundários (a) e retroespalhados (b).

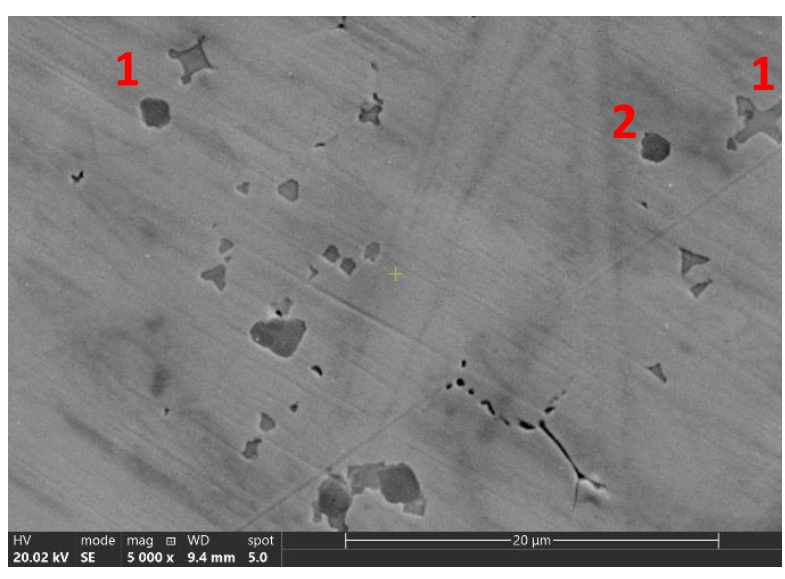

(a)

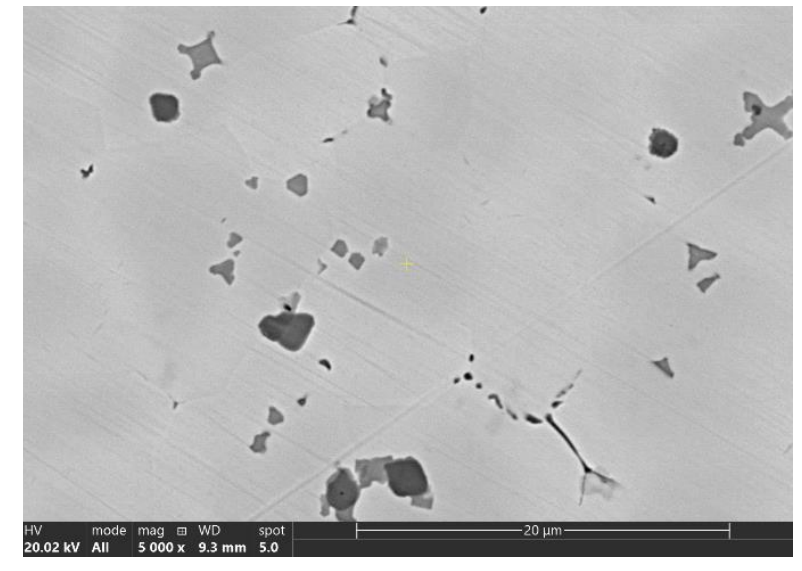

(b)

Fonte: autor

Nota-se na imagem 5.2a superfície do lingote poros nos pontos mais escuros e uma série de inclusões. As inclusões podem ser melhor observadas na figura $5.2 \mathrm{~b}$ com imagem obtida por elétrons retroespalhados. É possível perceber tons diferentes de cinza e formas diferentes dos defeitos. Na parte superior da imagem é possível observar uma tonalidade mais clara em forma de $\mathrm{X}$ identificado com o número 1, enquanto distribuído pelo quadro se vê pontos mais escuros identificado como número 2. A composição destas inclusões foi determinada por uma análise de energia dispersiva de raios $\mathrm{X}$ (EDX). Na figura 5.4 são apresentados os mapas de EDX para os elementos U, Mo, O e C. 
Figura 5.4 - Imagem do lingote bruto de fusão e respectivos mapas EDX dos elementos U, Mo, O e C.

$\mathrm{U}$
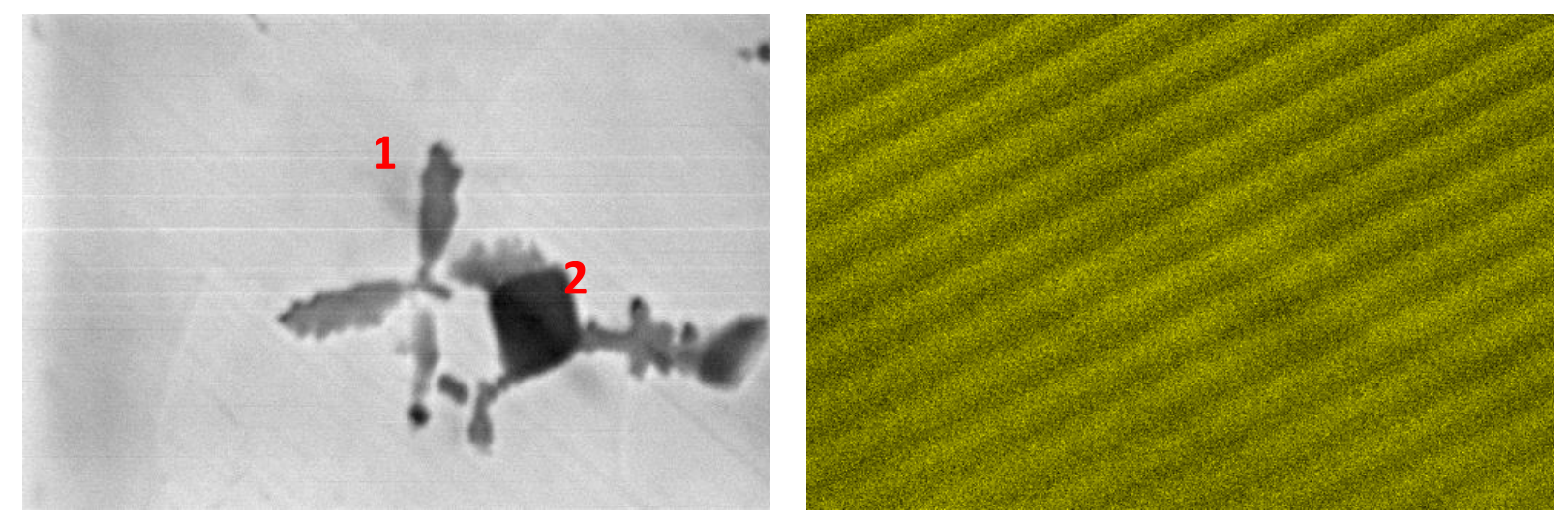

Mo

$\mathrm{O}$
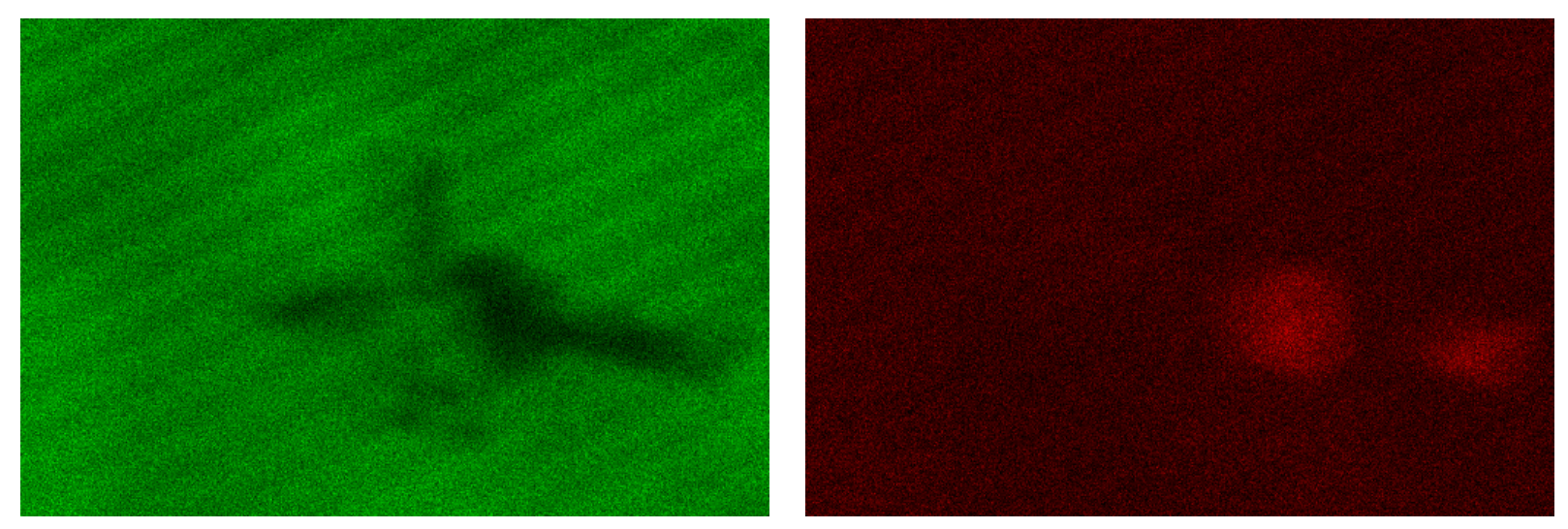

$\mathrm{C}$

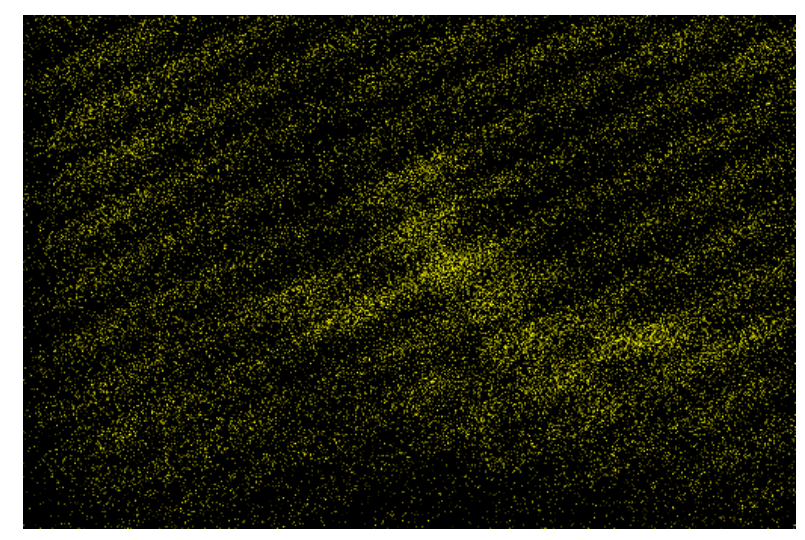

Fonte: autor

Como pode ser visto na figura 5.4, o urânio está presente em todo o quadro na matriz e nas inclusões de maneira uniforme. Já no mapa referente ao Mo, observa-se nitidamente a ausência do elemento nos partes acinzentados da respectiva imagem, 
indicando que as inclusões são preferencialmente de algum composto de uranio. No mapa do oxigênio, tem-se concentração de oxigênio apenas em parte das inclusões mais escuras representados pelo ponto 2 indicando a presença de óxido de urânio.. Nas partes cinzas mais claras, no ponto 1, aparece um aumento da concentração de carbono indicando a existência de carbeto de urânio. Sugere-se que este composto seja proveniente do urânio metálico puro utilizado na fusão. Como o carbono é um elemento leve para análise por EDX, foi realizada uma varredura no ponto da inclusão para confirmação da informação obtida pelo mapa. Na figura 5.5 é apresentada a varredura sobre a inclusão onde indica presença de carbono.

Figura 5.5 - Varredura para identificação de carbono na inclusão presente no lingote de U7Mo

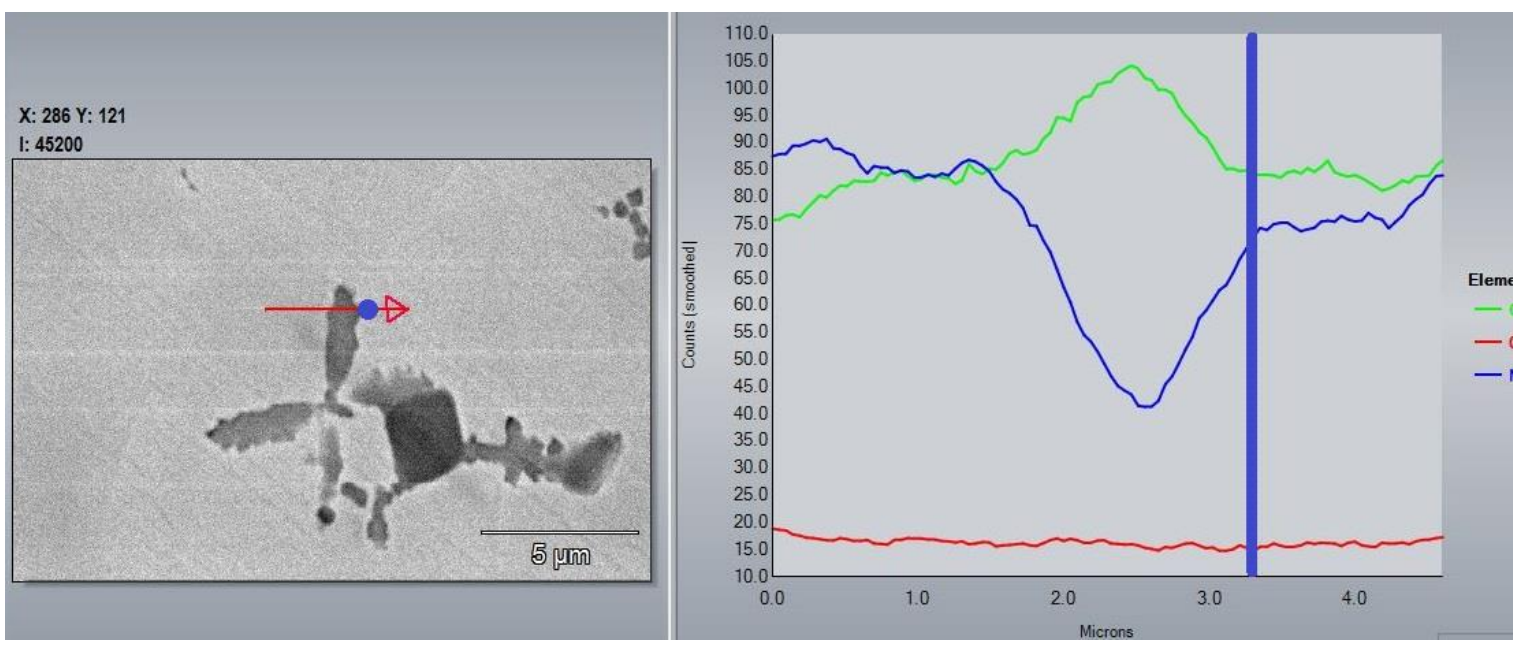

Fonte: autor

Quando a varredura passa pela matriz de U7Mo temos a presença constante de Mo, ao chegar na inclusão observa-se a queda de Mo e o aumento de C até a matriz. Notase que o nível de oxigênio é constante no ponto amostrado.

Antes do início da hidretação, o lingote passou pelo processo de decapagem conforme descrito no item 4.3.2. Nas figuras 5.6 a e 5.6 b são apresentadas as micrografias obtidas por MEV da superfície do lingote após decapagem.

Nota-se nas imagens uma superfície bem irregular com uma grande incidência de pontos mais escuros revelados após ataque químico. Os defeitos na superfície são importantes para a penetração de hidrogênio no interior do metal que, ao se acumular nestes pontos atinge seu limite de solubilidade e inicia a reação de hidretação como descrito no item 3.3.4. 
Figura 5.6 - Imagem MEV do lingote após decapagem

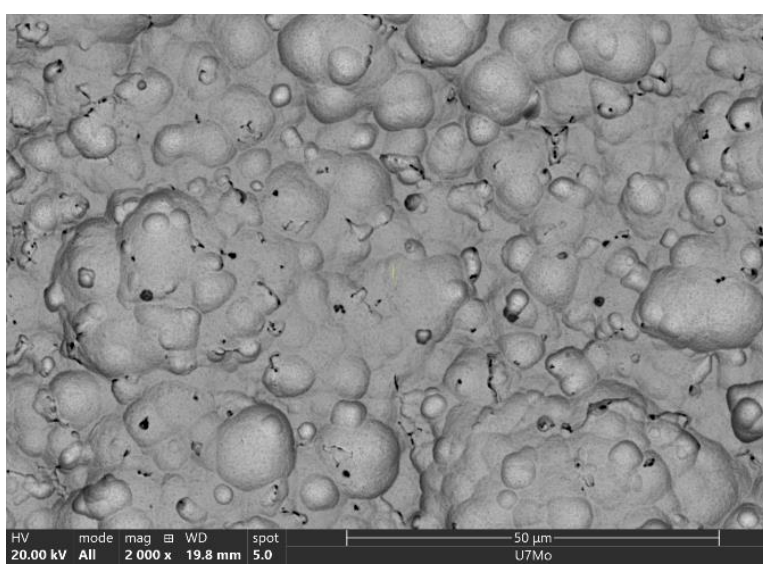

(a)

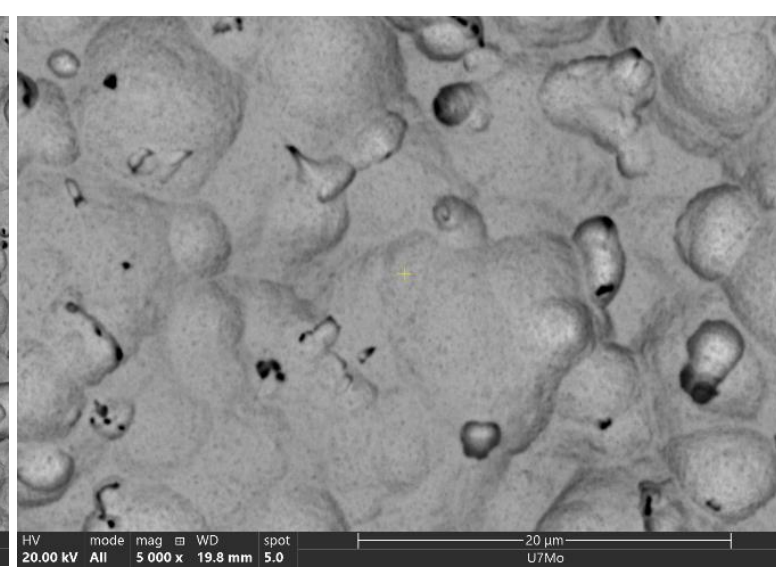

(b)

Fonte: autor

\subsection{Hidretação-Moagem-Desidretação}

O procedimento adotado foi o de intercalar ciclos de hidretação e moagem como descrito no item 4.3.3. Após a realização do primeiro ciclo, o cadinho foi retirado da retorta e o material foi moído e peneirado no interior da caixa de luvas inertizada com argônio. O material ainda acima da granulometria desejada retornou para um segundo ciclo de hidretação, e assim sucessivamente.

Das peças cortadas, foram utilizadas as de massa: 115,33 g, 100,34 g, 123,89 g e 118,36 g, totalizando uma massa de 457,92 g. Entretanto, após a decapagem houve uma perda de quase $25 \%$ de massa nas peças, totalizando um lote de 352,44 g para a hidretação.

Para hidretação total desse lote, foram necessários 6 ciclos de hidretação. As peças foram aquecidas a $700{ }^{\circ} \mathrm{C}$ com uma pressão inicial de 2 bar. O primeiro ciclo foi realizado apenas com 2 peças cortadas para verificar o comportamento do sistema, totalizando 176,98 g. A partir do terceiro ciclo foi colocada a massa total a ser pulverizada, adicionando-se 175,46 g no sistema. Entretanto, no quarto ciclo foram retirados 71,73 g para evitar aumento excessivo de pressão na retorta, visto que no anterior a pressão do sistema alcançou o valor de 9,27 bar. Este aumento de pressão se deve ao desprendimento do gás hidrogênio que estava no metal, reagido ou adsorvido, do ciclo anterior durante o aquecimento. No quinto ciclo a massa retirada retornou ao processo. A perda do processo HMD foi de 9,5\% em massa durante as etapas de moagem e peneiramento dentro da caixa 
de luvas. Na tabela 5.1 tem-se a massa produzida em cada ciclo e a porcentagem em relação a massa inicial de cada ciclo.

Tabela 5.1 - Massa produzida por ciclo de hidretação

\begin{tabular}{c|c|c|c|c|c}
\hline \multirow{2}{*}{ Hidretação } & \multirow{2}{*}{$\begin{array}{c}\text { Massa inicial } \\
\text { hidretação }(\mathrm{g})\end{array}$} & \multicolumn{2}{|c|}{ FGD } & \multicolumn{2}{c}{ FGF } \\
\cline { 3 - 6 } & & $(\mathrm{g})$ & $\%$ & $(\mathrm{~g})$ & $\%$ \\
\hline 1 & 176,98 & 16,72 & 9 & 6,23 & 4 \\
\hline 2 & 150,85 & 24,54 & 16 & 11,44 & 8 \\
\hline 3 & 284,45 & 43,27 & 15 & 16,87 & 6 \\
\hline 4 & 149,62 & 45,42 & 30 & 21,72 & 15 \\
\hline 5 & 147,49 & 46,58 & 32 & 19,77 & 13 \\
\hline 6 & 74,13 & 47,04 & 63 & 19,47 & 26 \\
\hline
\end{tabular}

Fonte: autor

Observa-se que o primeiro ciclo é o que obtem o menor rendimento em relação a massa inicial pois o material ainda está intacto, a partir de sua fragmentação, a hidretação começa a ser mais acentuada provavelmente em razão da existência de maior área superficial para adsorção de hidrogênio e posterior reação. A produção de pós FGF também aumenta ao longo dos ciclos. O processo de moagem realizado manualmente em almofariz e pistilo não permite o controle efetivo da granulometria, fazendo com que uma maior intensidade na moagem ou mesmo maior quantidade de pó no almofariz possam vir a gerar resultados diferentes, gerando mais ou menos pós finos por batelada.

As imagens apresentadas na figura 5.7 mostram o comportamento do lingote nos diferentes ciclos de hidretação.

Após o primeiro ciclo, as peças ficaram como mostrado na figura 5.7 b e 5.7 c após a retirada da retorta e moagem, respectivamente. É possível observar que o lingote ainda tem pedaços intactos que não foram totalmente hidretados. Este comportamento foi observado em testes prelimiares de hidretação, onde peças provenientes do mesmo lingote não obtiveram o mesmo resultado no primeiro ciclo. Na figura 5.8 tem-se uma foto de 2 peças após a primeira hidretação onde uma se fragmentou totalmente e a outra ficou intacta e. A figura 5.7 d mostra a carga do cadinho nas hidretações intermediarias onde pode se 
observar pedaços maiores de material grandes com, porém com uma aparência de pequenas camadas se desprendendo da peça e uma grande concentração de pós que estão acima da faixa granulométrica desejada. A imagem 5.7 e mostra o cadinho após a moagem antes da última hidretação, pode-se observar que o número de pedaços maiores é quase que inexistente e o pó já está bem fino. A figura 5.7 f mostra o pó final obtido por todo o processo. Importante ressaltar que a insistência em moer o pó acima da faixa para diminuir o número de bateladas pode resultar numa concentração alta de pós FGF.

Figura 5.7 - Fotos do processo de hidretação do lingote para as placas: lingote após decapagem (a); fragmentação da peça após primeira hidretação (b); peça a ser hidretada após moagem (c); hidretações intermediárias (d); material para última hidretação (e), pó final (f)

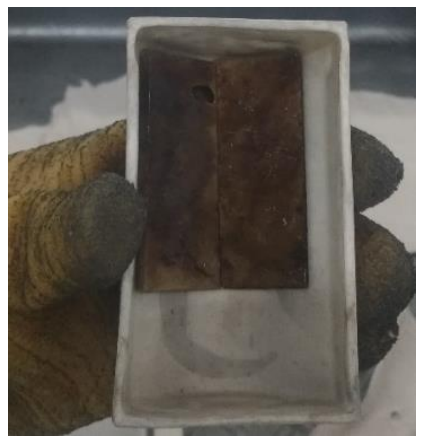

(a)

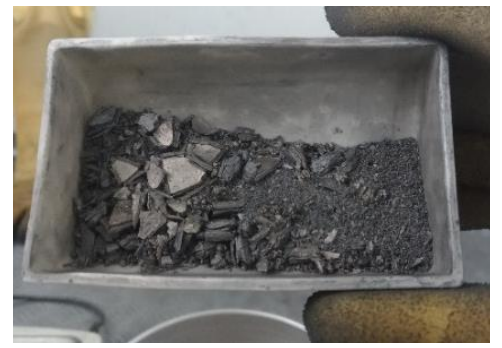

(d)

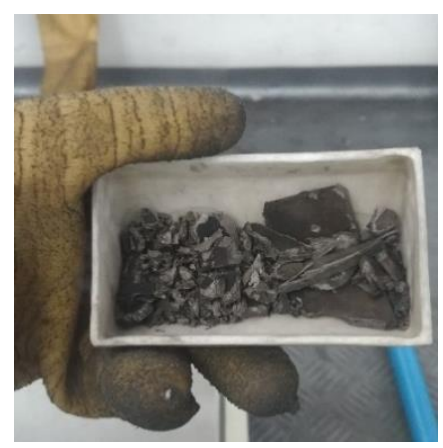

(b)

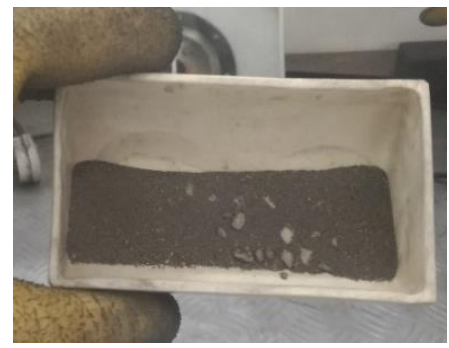

(e)

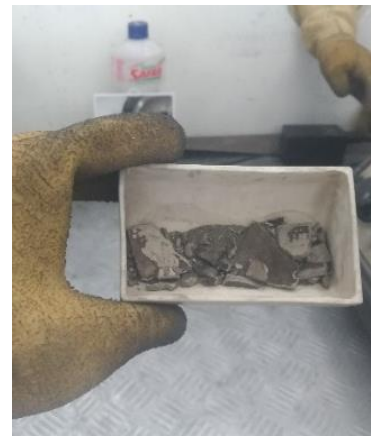

(c)

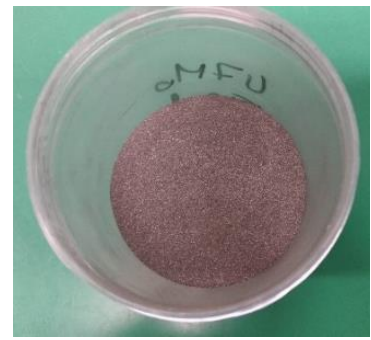

(f)

Fonte: autor

A peça intacta não conseguiu ser moída, pois não estava hidretada. Entretanto, em ciclos posteriores ambas as peças foram totalmente pulverizadas. A caracterização superficial apresentada no item 5.1 não foi suficiente para explicar o porquê da ocorrência de hidretações tão irregulares. Sugere-se um estudo aprofundado para determinar quais as propriedades do lingote que influenciam no início da hidretação. 
Embora o comportamento das 4 peças hidretadas tenha sido semelhante em todos os ciclos, ainda não se é possível determinar condições de reprodutibilidade para o processo de hidretação

Figura 5.8 - Foto 2 peças provenientes do mesmo lingote nas mesmas condições de hidretação

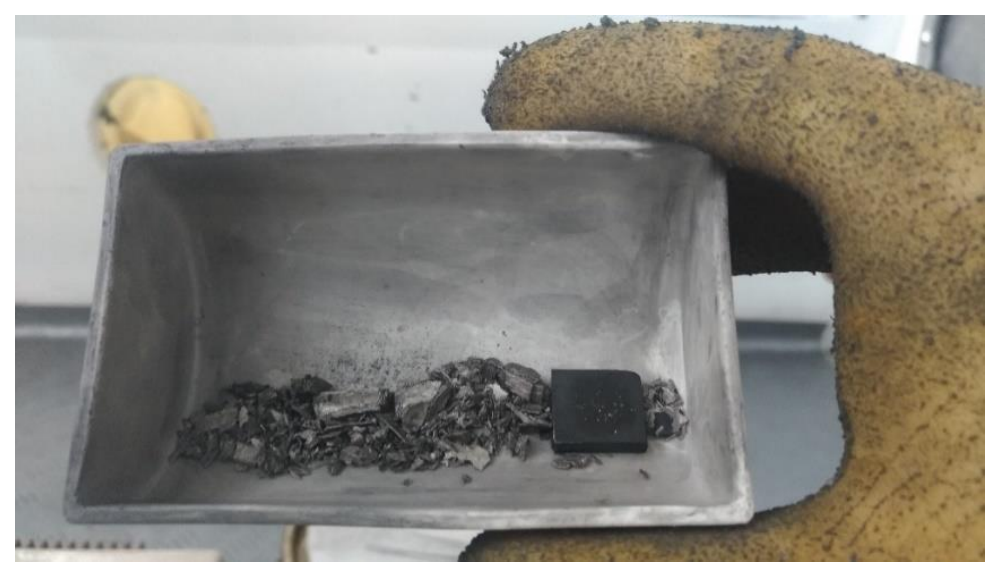

Fonte: autor

Durante o aquecimento até $700{ }^{\circ} \mathrm{C}$, além do aumento de pressão devido ao aumento de temperatura, também ocorreu um aumento significativo de pressão ao longo dos ciclos de hidretação. Em teste realizado previamente às hidretações, o sistema com a retorta vazia sem metal chegou em uma diferença de pressão de 2,39 bar. O ciclo 1 teve uma variação de pressão de 1,90 bar, já o ciclo 2 de 6,53 bar e o ciclo 5 de 10,95 bar. Quanto mais pulverizada a peça se observa uma maior diferença de pressão no sistema. Importante ressaltar que o ciclo 4 obteve uma variação de pressão menor, pois parte da massa foi retirada do ciclo para evitar o aumento excessivo de pressão no sistema. Na figura são mostradas as variações de pressão nos diferentes ciclos realizados. 
Figura 5.9 - Curvas de pressão e temperatura por tempo para os diferentes ciclos de hidretação
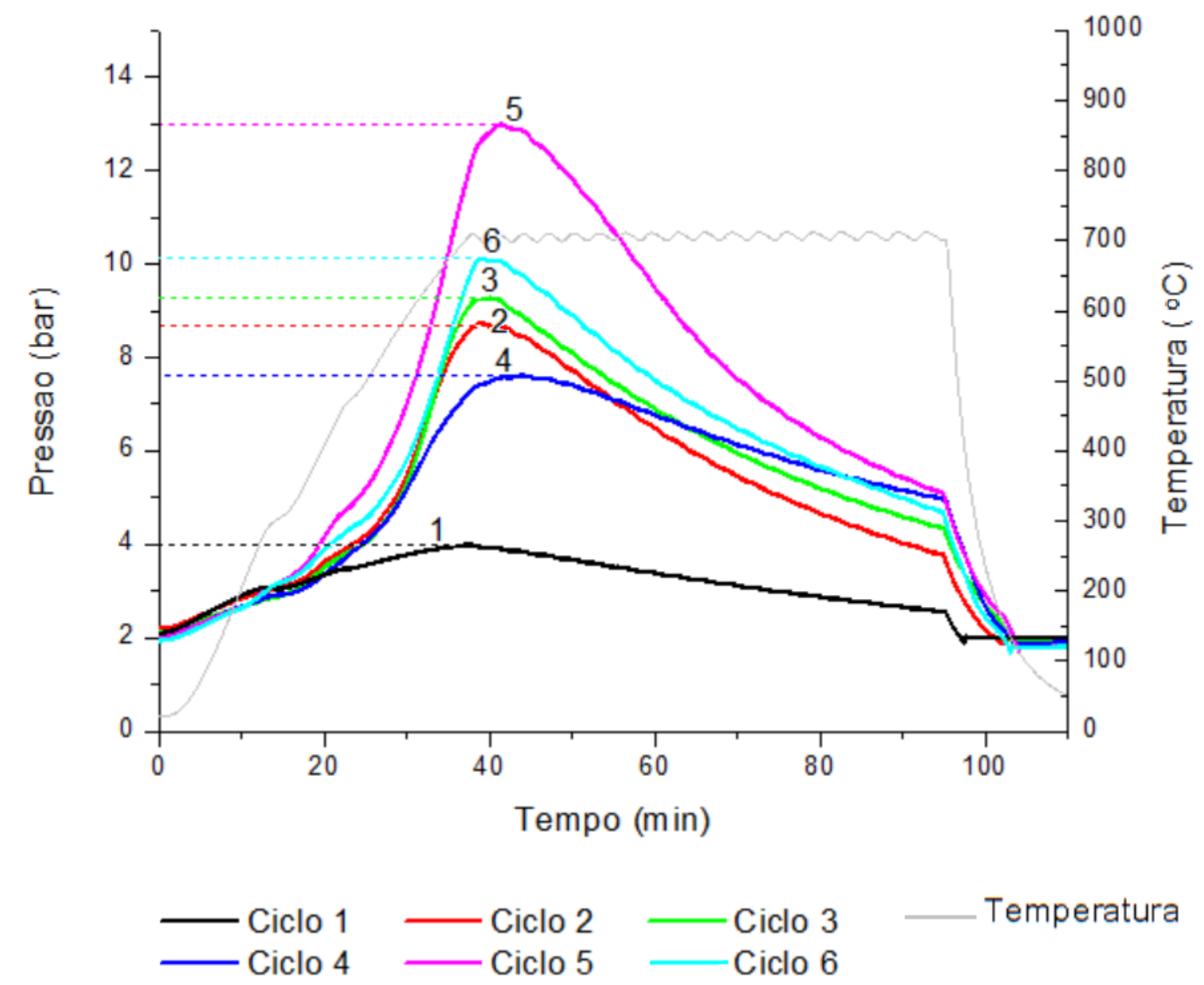

Fonte: autor

Observa-se uma queda de pressão durante o patamar de $700{ }^{\circ} \mathrm{C}$. Esta queda já vista em testes anteriores foi atribuída a possíveis vazamentos. Quando o sistema é resfriado, a queda de pressão é acentuada e retorna ao valor inicial próximo de 2 bar.

O total de pó obtido na faixa granulométrica após as hidretações foi de 188,89 g. Após a obtenção da quantidade de pó desejada foi realizada a desidretação do material.

A desidretação foi realizada a $700{ }^{\circ} \mathrm{C}$ com uma rampa de aquecimento de $5{ }^{\circ} \mathrm{C}$ min $^{-1}$. Na figura 5.10 tem-se as curvas de desidretação para os pós FGD e FGF. 
Figura 5.10 - Curvas de pressão e temperatura por tempo para o processo de desidretação dos pós FGD e FGF
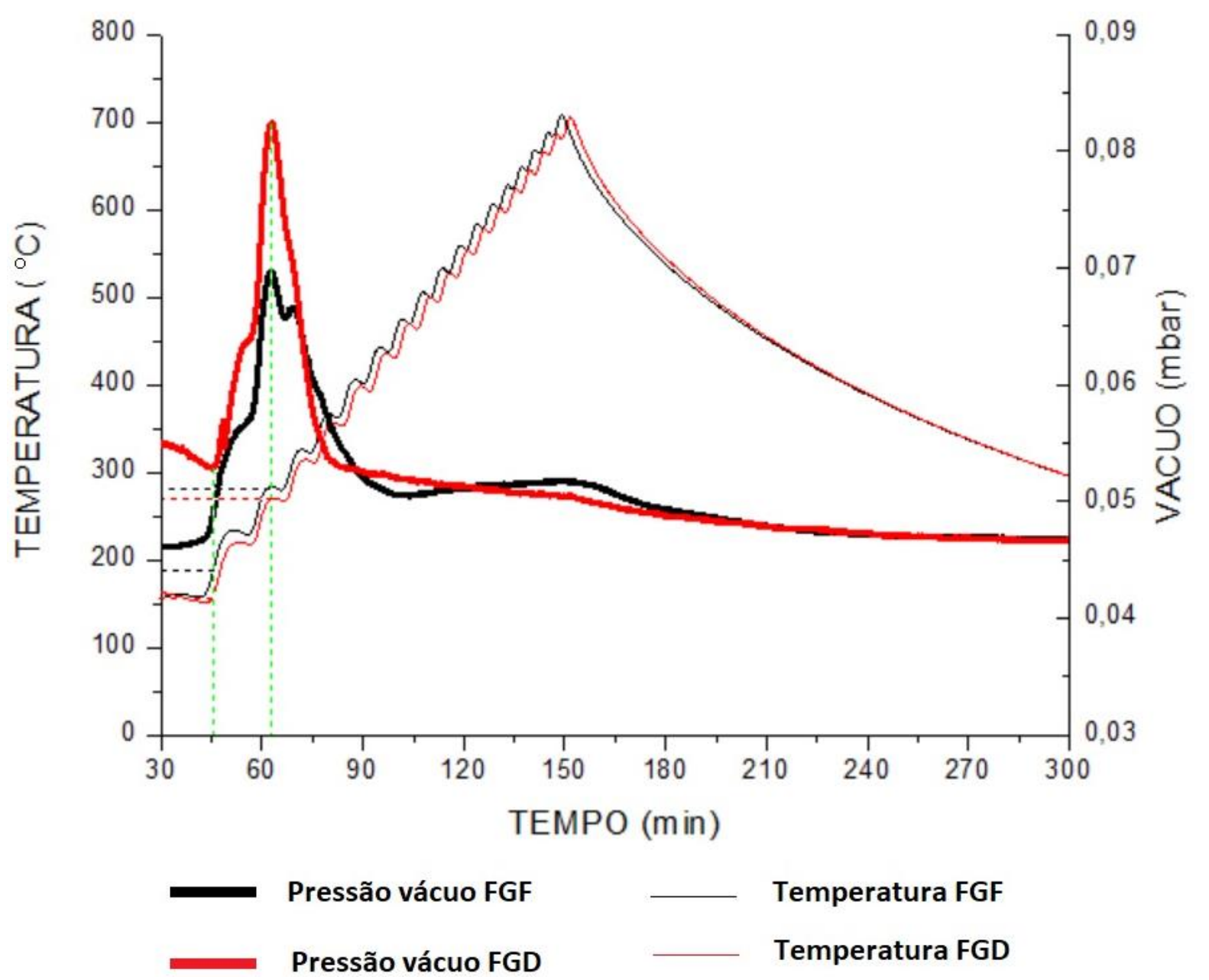

Fonte: autor

Observa-se que o início da do aumento da pressão no sistema ocorre próximo a $150{ }^{\circ} \mathrm{C}$, indicando que o gás está sendo liberado do metal. A partir de $400{ }^{\circ} \mathrm{C}$ todo o material já foi praticamente desidretado, uma vez que a pressão se torna praticamente estabilizada próxima do seu valor inicial. Os leves degraus observados nas curvas de pressão de vácuo são decorrentes do modo como o sistema de controle de temperatura atua sobre o forno durante o aquecimento. A intensidade maior da curva para pós FGD se deve a maior quantidade de material hidretado no sistema.

Após a desidretação, houve uma diminuição de 5\% da massa FGD e acréscimo no FGF. Isto ocorre pela variação de volume do hidreto para o metal durante a desidretação. O pó final obtido teve $20 \%$ de pós FGF incorporado ao pó FGD. Visto que a produção de 
pós abaixo da faixa granulométrica desejada é inevitável no processo utilizado, a adição de pós finos ao pó final é uma estratégia para melhor aproveitamento do processo de cominuição, além de melhorar a dispersão sem comprometer a continuidade da matriz.

A massa total para fabricação das placas foi de 262,05 g, equivalendo a um rendimento de $74 \%$ na hidretação em relação ao lingote no início da hidretação.

\subsubsection{Caracterização dos pós}

Foram realizadas as análises por difração de raios X para os pós hidretados e desidretados para verificação se houve a retenção da fase $\gamma \mathrm{U}$, assim como análise do nível de óxido no combustível após todo o processo de HMD.

Os difratogramas de raios $\mathrm{X}$ dos pós hidretados e desidretados são apresentados nas figuras 5.11 e 5.12, respectivamente.

Observa-se picos de $\mathrm{UO}$ e $\mathrm{UO}_{2}$ inexistentes quando comparado com a figura 5.5. Sendo os picos de difração dos compostos UO e UC muito semelhantes, e sabendo-se da existência de carbono previamente no lingote, não é possível afirmar que todo os picos indicados de UO são realmente apenas de UO, entretanto não é de se esperar o aumento da presença de UC durante a hidretação. A presença de picos de UO indica que ocorreu diferentes níveis de oxidação apresentando $\mathrm{UO}$ e $\mathrm{UO}_{2}$. Nota-se também que não foram detectados picos referentes ao hidreto metálico. Esta informação é corroborada na literatura quando se sugere amorficidade da estrutura cristalina do hidreto $\gamma \mathrm{U}$ ou da presença de uma estrutura nanométrica [34, 44].

Quando se analisa a figura 5.12, os picos referentes a fase $\gamma \mathrm{U}$ reaparecem indicando que o material retornou à forma metálica e os óxidos formados na etapa de hidretação permaneceram no pó final. A presença de óxidos, embora não comprometa o comportamento do combustível durante a irradiação, não é desejada porque indica a diminuição da densidade de urânio no combustível. É possível concluir que o processo HMD como realizado aumentou a oxidação do material já existente no lingote. Sugere-se que a estanqueidade da caixa de luvas e do sistema de hidretação, assim como o nível de vácuo durante a desidretação podem ser a fonte de oxidação no sistema. As fichas de difração para comparação dos picos de $\mathrm{UO}_{2}$ e UO foram as 5-550 e 17-659, respectivamente. 
Figura 5.11 - Difratograma de raios X do pó de U7Mo hidretado

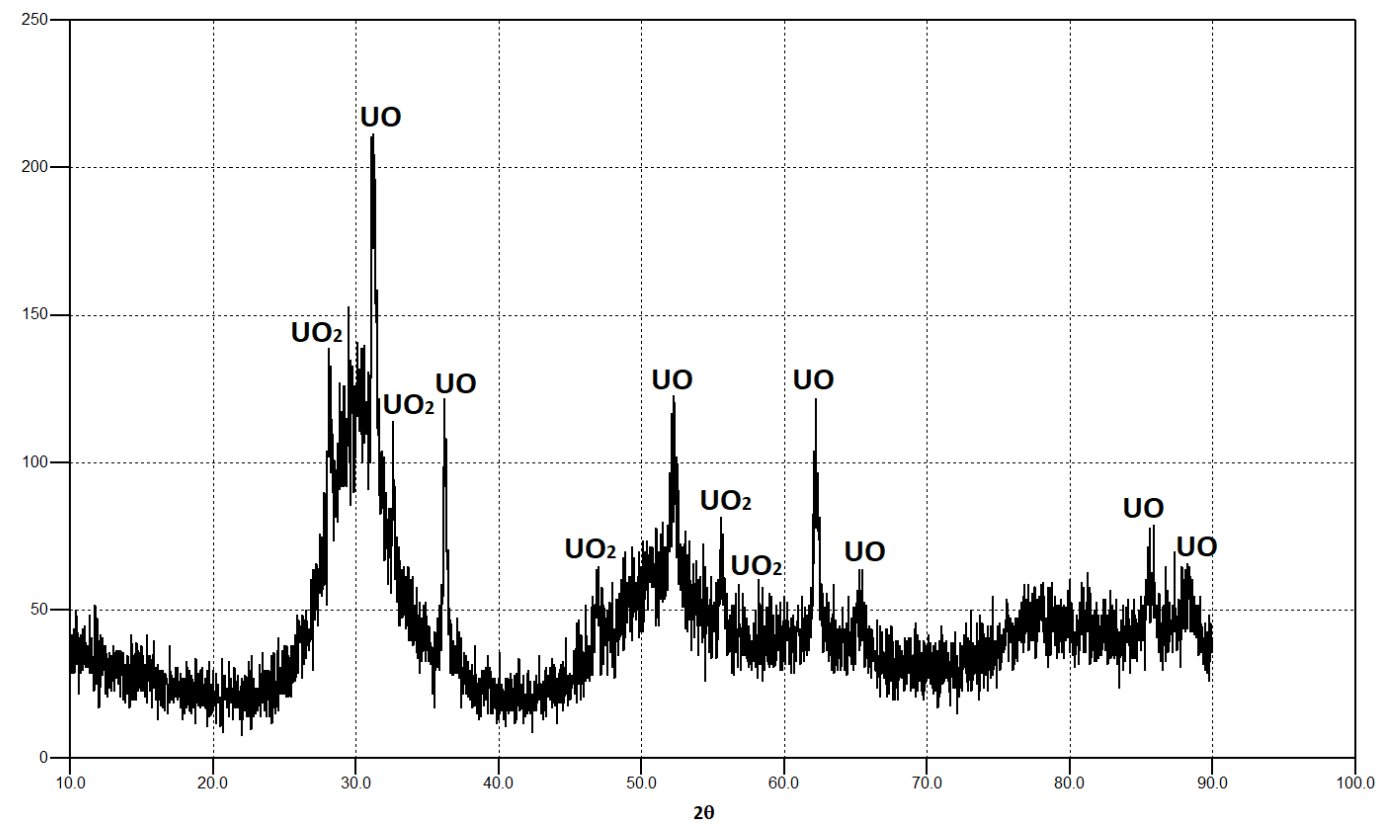

Fonte: autor

Figura 5.12 - Difratograma de raio X do pó U7Mo final

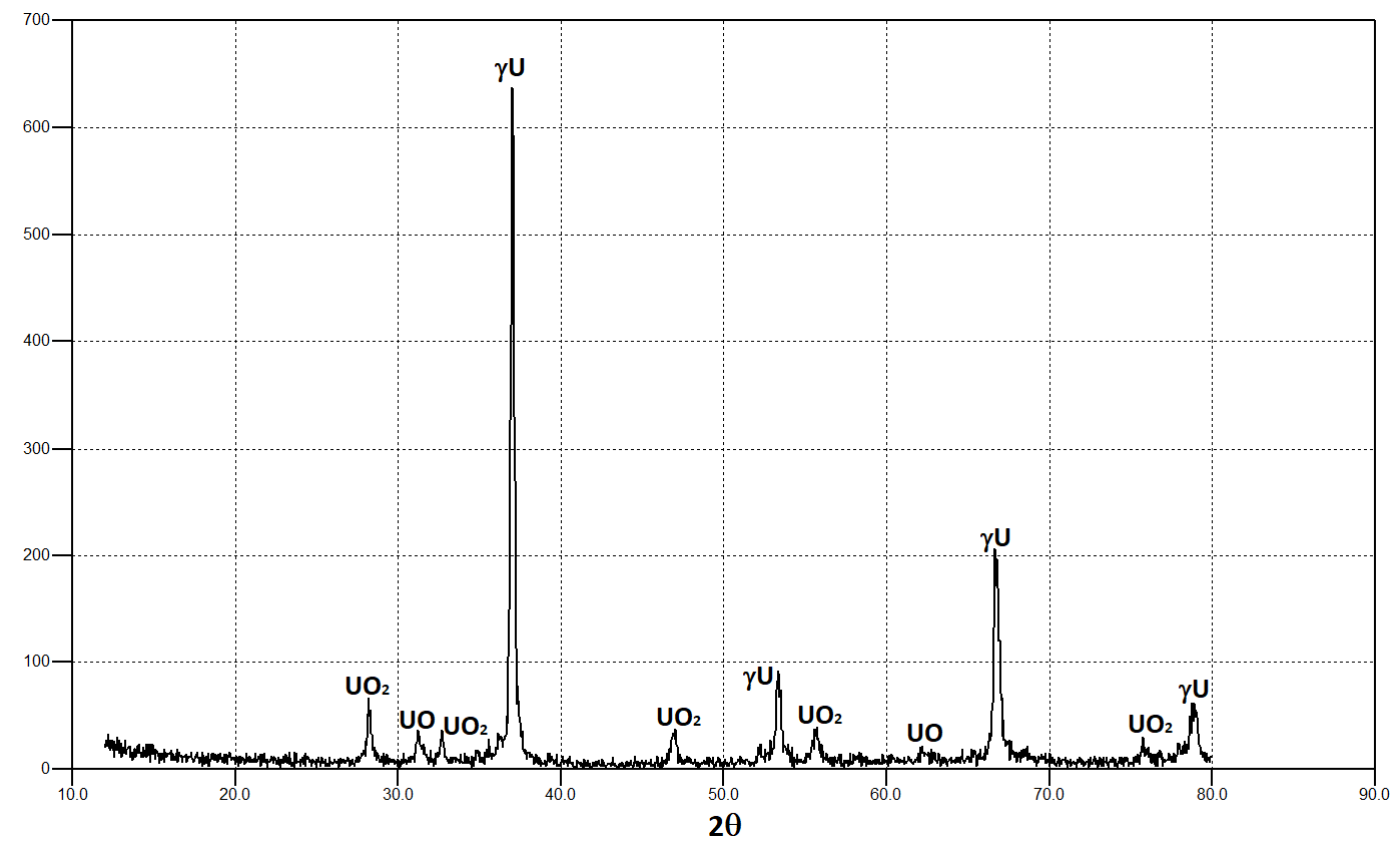

Fonte: autor

A morfologia do pós foi analisada por MEV e as micrografias são apresentadas nas figuras 5.13 . 
Figura 5.13 - Imagem obtida por MEV com elétrons secundários do pó hidretado FGD (a, b) e do pó final (c, d)

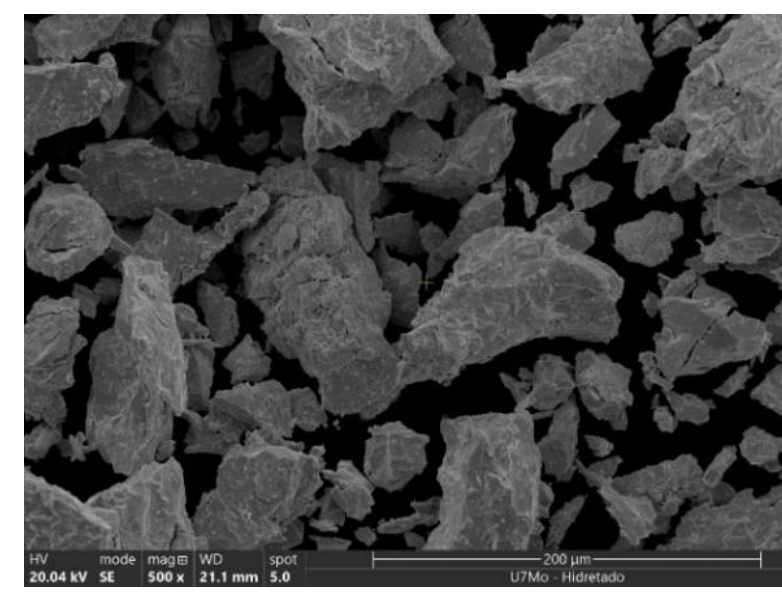

(a)

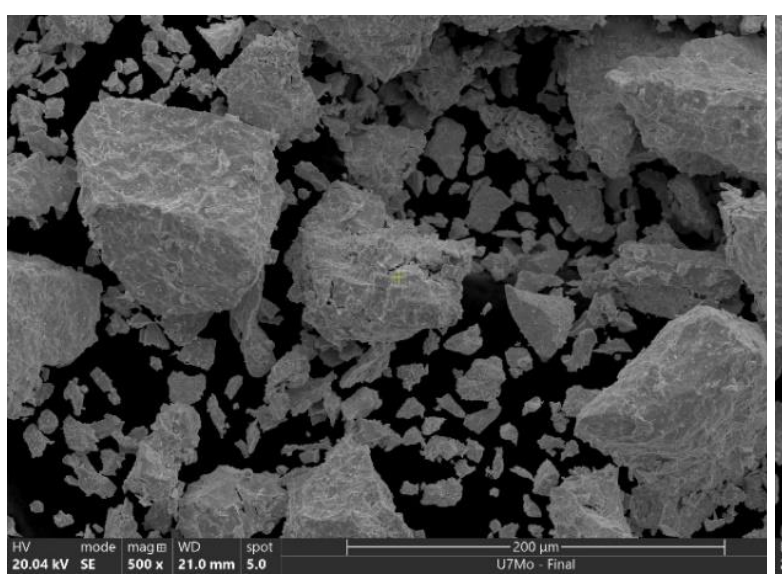

(c)

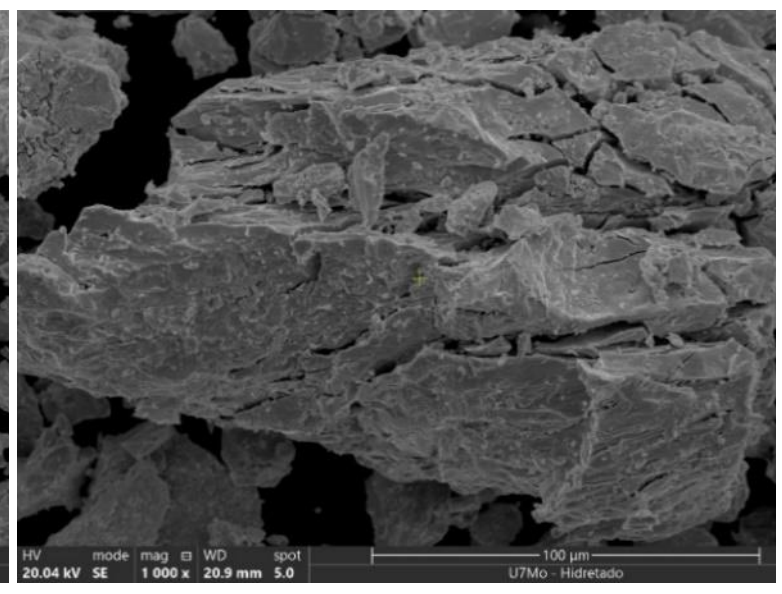

(b)

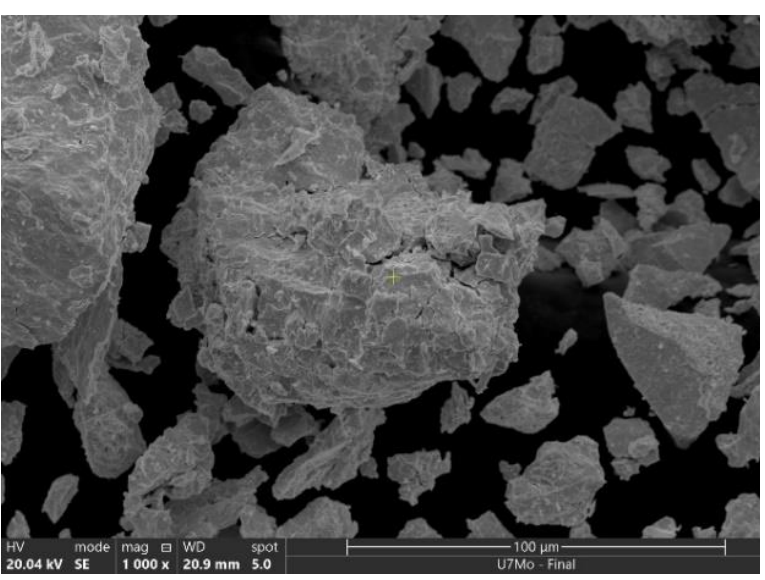

(d)

Fonte: autor

Da figura 5.13 a observa-se partículas do pó hidretado com formas irregulares, em sua grande maioria com pontas devido à decrepitação da peça. Também é possível ver trincas na superfície das partículas em detalhe na figura 5.13 b. Nas figuras 5.13 c e 5.13 d, nota-se a permanência de trincas nas partículas desidretadas. O formato permanece irregular como descrito anteriormente para o pó hidretado, não alterando significativamente a morfologia após a desidretação.

A massa específica do pó final foi analisada através da técnica de picnometria de hélio. A massa específica obtida foi de $16,63 \mathrm{~g} \mathrm{~cm}^{-3}$. Para uma liga de U7Mo a massa específica teórica é de $17,97 \mathrm{~g} \mathrm{~cm}^{-3}$. O valor obtido experimentalmente abaixo da densidade da liga pode ser explicado pelo aumento da oxidação durante o processo HMD. Em adição, 
a presença de trincas observadas na figura $5.13 \mathrm{~d}$, permite que o hélio penetre no interior da partícula superestimando a densidade aparente do pó.

\subsection{Briquete}

Os cálculos de massa foram feitos a partir da densidade de urânio desejada em cada placa em relação ao volume da matriz do briquete.

Para fins de notação deste trabalho os briquetes serão identificados pelos números 1 e 2 correspondentes às densidade de urânio de $4 \mathrm{gU} \mathrm{cm}^{-3}$ e $7 \mathrm{gU} \mathrm{cm}^{-3}$, respectivamente.

Após a pesagem, mistura e homogeneização, o pó foi cuidadosamente colocado e distribuído na cavidade da matriz da prensa. A carga da prensa aplicada foi de 280 ton, resultando em uma pressão de 5 ton $\mathrm{cm}^{-2}$. Durante a retirada do briquete da matriz, foi possível observar nas bordas laterais ranhuras no briquete e trincas. Estas trincas e ranhuras acontecem no processo de extração do briquete na matriz, não sendo desejadas para a próxima etapa de laminação. A figura 5.14 mostra foto do briquete finalizado e detalhe de trinca.

Os briquetes foram medidos em 2 pontos para aferição do comprimento, 3 pontos para a largura e 12 pontos para a espessura. Os valores dimensionais dos briquetes e suas respectivas massas estão apresentados na tabela. 5.2.

Figura 5.14 - Briquete vista superficial (a), detalhe de trinca e ranhuras na lateral do briquete (b)
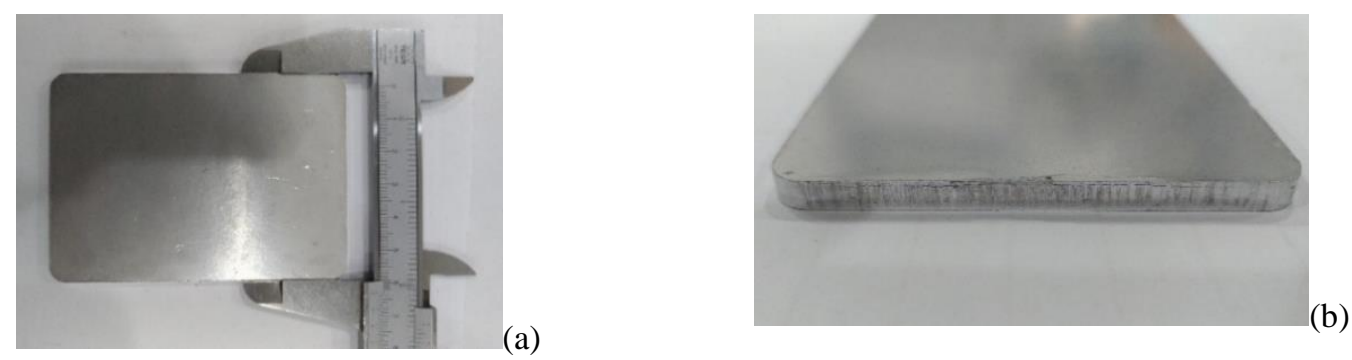

Fonte: autor 
Tabela 5.2. - Dimensões médias e massas dos briquetes de U7Mo

\begin{tabular}{c|c|c|c|c|c|c|c|c}
\hline \multirow{2}{*}{$\#$} & $\begin{array}{c}\text { Densidade U } \\
\left(\mathrm{gU} \mathrm{cm}^{-3}\right)\end{array}$ & \multicolumn{2}{|c|}{$\begin{array}{c}\text { Comprimento } \\
(\mathrm{cm})\end{array}$} & \multicolumn{2}{|c|}{$\begin{array}{c}\text { Largura } \\
(\mathrm{cm})\end{array}$} & \multicolumn{2}{|c|}{$\begin{array}{c}\text { Espessura } \\
(\mathrm{cm})\end{array}$} & \multirow{2}{*}{$\begin{array}{c}\text { Massa } \\
(\mathrm{g})\end{array}$} \\
\cline { 2 - 7 } & MIN & MAX & MIN & MAX & MIN & MAX & \\
\hline 1 & 4 & 89,61 & 89,62 & 62,60 & 62,74 & 3,74 & 3,86 & 129,72 \\
\hline 2 & 7 & 89,73 & 89,75 & 62,67 & 62,68 & 3,92 & 3,96 & 185,74 \\
\hline
\end{tabular}

Fonte: autor

Os valores observados na tabela 5.2 mostram que o briquete 2, com maior densidade de urânio, apresentou valores acima dos especificados no cálculo e maior desvio nos valores medidos da largura e espessura. O aumento da concentração de U7Mo no briquete não permitiu que a carga aplicada na prensa fosse o suficiente para se chegar na espessura desejada. A criticidade em relação à espessura do briquete, é que sendo mais grossa que a moldura, durante a laminação da placa pode produzir defeitos pelo arraste de combustível entre a moldura e o revestimento.

Antes de seguir para a fabricação das placas os briquetes foram desgaseificados a uma temperatura de $230{ }^{\circ} \mathrm{C}$ sob um vácuo de $2,6710^{-5}$ bar e na sequência submetidos a um vácuo de $5,3310^{-7}$ bar.

A partir da razão entre o valor experimental e teórico da densidade do briquete, é calculada sua porosidade residual. A densidade teórica é calculada com base nos valores dos pós de Al e U7Mo pesados para cada briquete e sua relação proporcional de volume entre a liga e a matriz como demonstrado na equação 3 .

$$
\begin{gathered}
\rho_{\text {briquete }}=\frac{m_{U 7 M o}+m_{A l}}{\frac{m_{U 7 M o}}{\rho_{U 7 M o}}+\frac{m_{A l}}{\rho_{A l}}}=\frac{1}{\frac{X_{U 7 M o}}{\rho_{U 7 M o}}+\frac{X_{A l}}{\rho_{A l}}} \\
\text { onde } X_{U 7 M o}=\frac{m_{U 7 M o}}{\frac{m_{U 7 M o}+m_{A l}}{\rho_{U 7 M o}}} \text { e } X_{A l}=\frac{m_{A l}}{\frac{m_{U 7 M o}+m_{A l}}{\rho_{A l}}}
\end{gathered}
$$

A densidade experimental é calculada com base nos valores experimentais obtidos de dimensões e massa. A densidade experimental do briquete 1 foi de $6,18 \mathrm{~g} \mathrm{~cm}^{-3}$, comparando com o valor teórico calculado de $6,49 \mathrm{~g} \mathrm{~cm}^{-3}$, a porosidade residual foi mantida 
e 4,87\%. Já para o briquete 2 , a relação entre a densidade experimental, $8,51 \mathrm{~g} \mathrm{~cm}^{3}$, e a densidade teórica de $9,30 \mathrm{~g} \mathrm{~cm}^{-3}$ forneceu uma porosidade residual de 8,56\%.

\subsection{Placas}

O conjunto de revestimento, moldura e briquete foi montado com a inserção do briquete na moldura por interferência conforme descrito no item 4.5. A ilustração da montagem do conjunto pode ser vista na figura 5.15 .

Figura 5.15 - Conjunto revestimento, moldura e briquete: revestimento e briquete (a), moldura e briquete (b), perfil conjunto montado (c), perfil conjunto soldado (d).

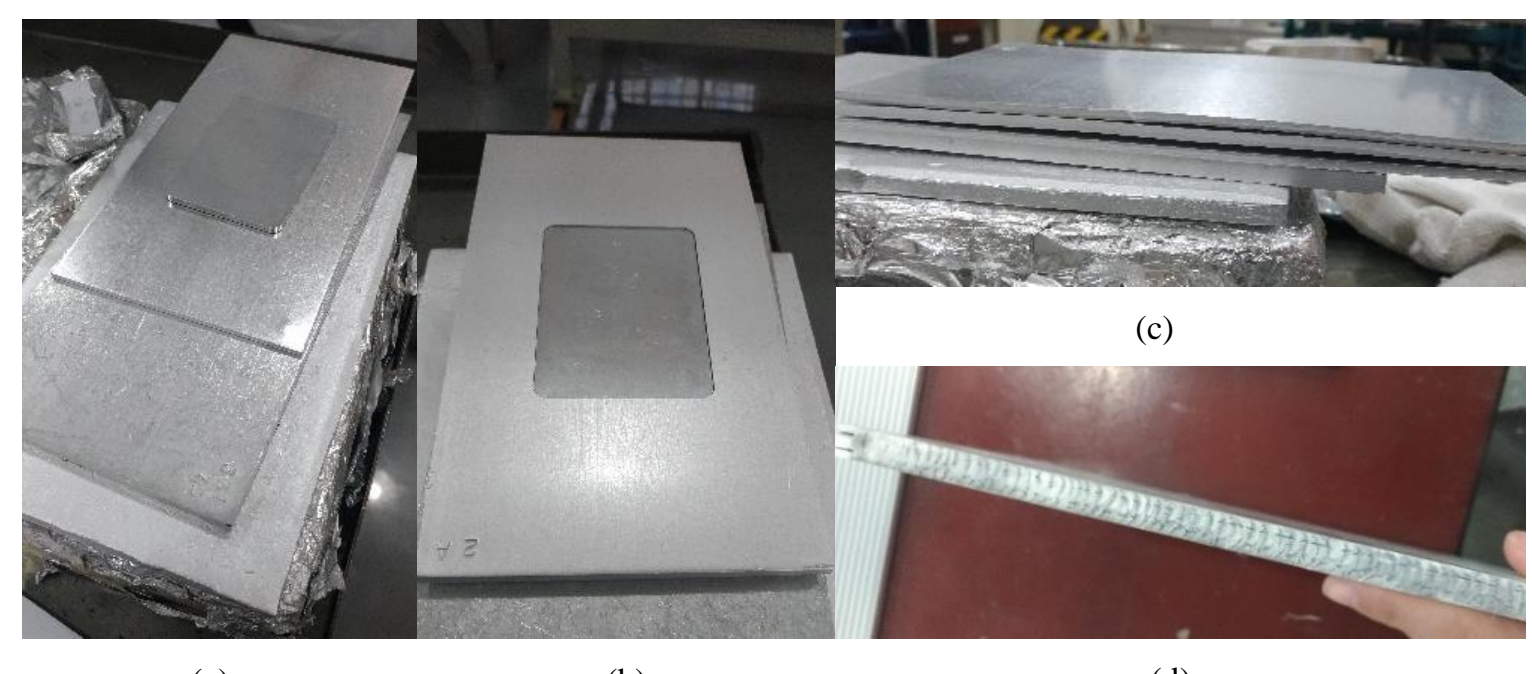

(a)

(b)

(d)

Fonte: autor

Os revestimentos e molduras passaram por processo de decapagem com soda cáustica 50\% e ácido nítrico. As peças de alumínio foram lavadas e guardadas em estufa até o início da montagem do conjunto e laminação.

Os conjuntos foram laminados conforme descrito no item 4.5.1. A cada passe a espessura das placas eram medidas e em seguida o laminador era ajustado para o próximo passe. Durante a laminação, tomou-se cuidado para não ocorrer a envergadura da placa. A figura 5.16 apresenta a evolução do tamanho do conjunto durante a laminação. 
Figura 5.16 - Evolução da laminação: $1^{\circ}$ passe (a), passes intermediários (b, c), último passe (d)

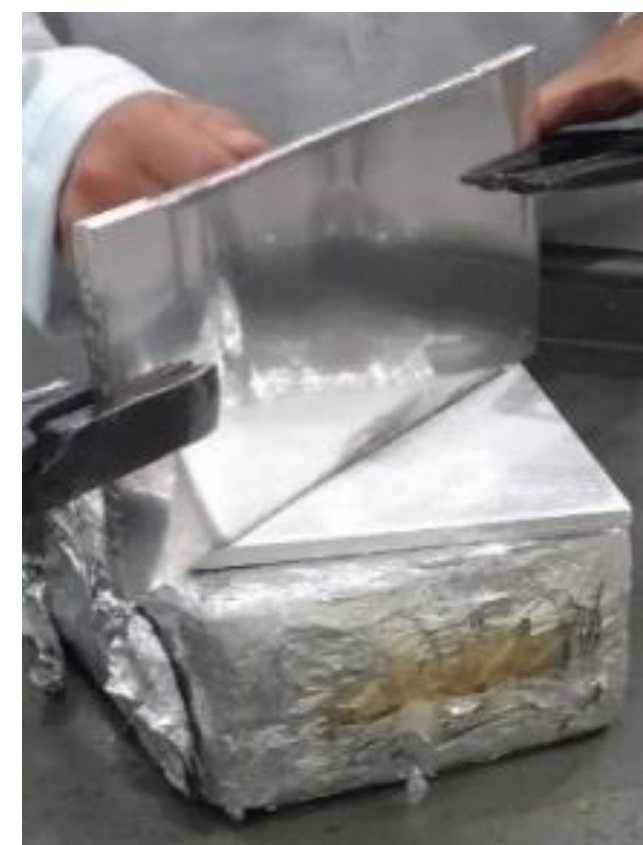

(a)

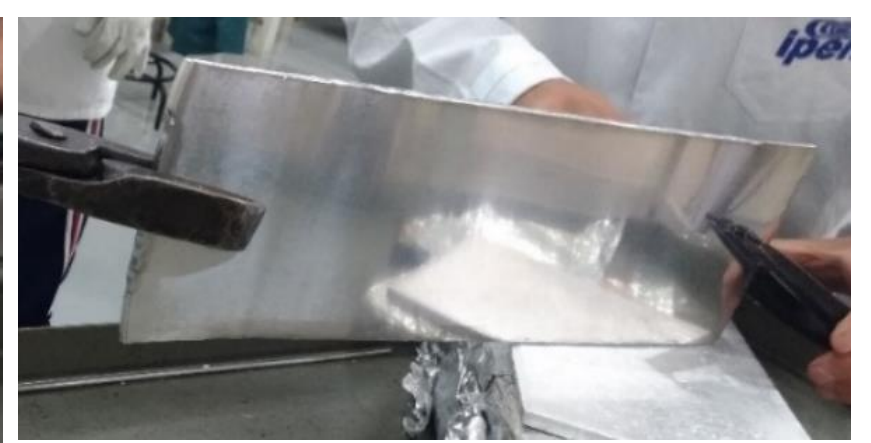

(b)

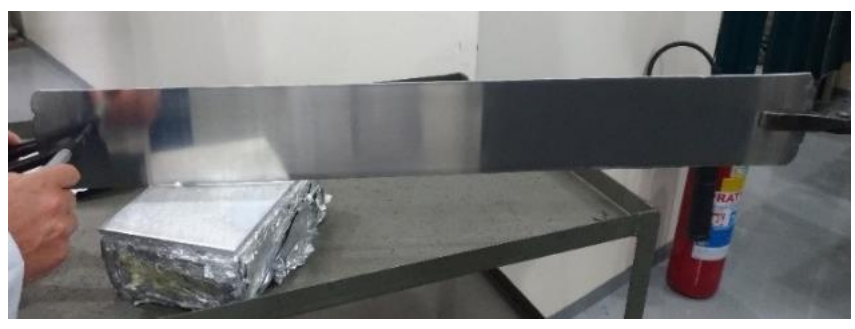

(c)

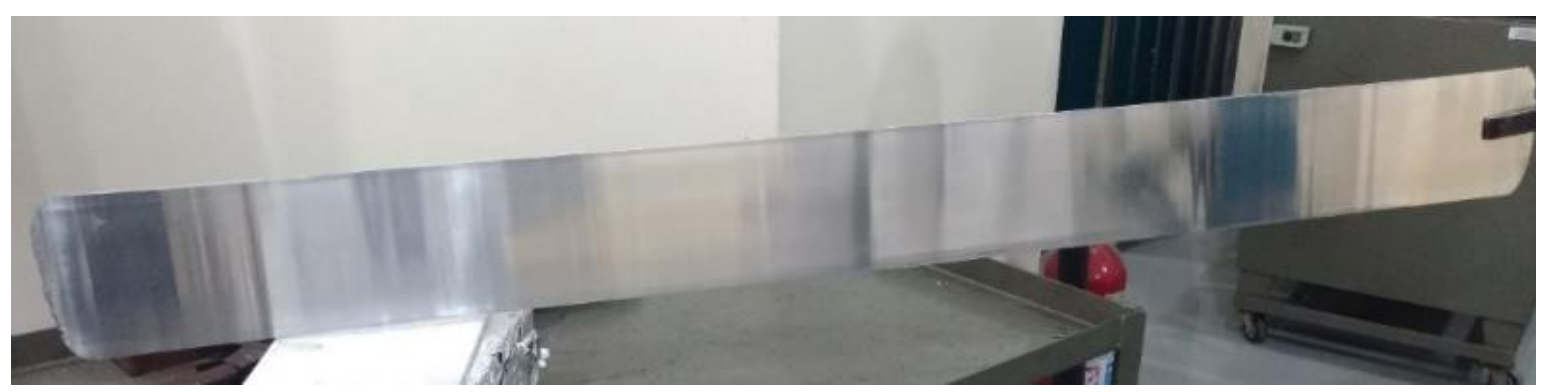

(d)

Fonte: autor

Analogamente aos briquetes, as placas serão denominadas 1 e 2 para os núcleos com 4 e $7 \mathrm{gU} \mathrm{cm}^{-3}$, respectivamente.

Após a laminação a quente, foram realizados 2 passes de laminação a frio para ajuste da espessura. Para a placa 1 foi possível chegar na espessura de 1,34 mm. A placa 2, ficou 0,02 mm acima da especificação, sendo, então, realizado mais um passe de laminação a frio de ajuste. $\mathrm{O}$ valor final da espessura foi de $1,35 \mathrm{~mm}$, entretanto o comprimento do núcleo atingiu em $635 \mathrm{~mm}$. Desta maneira, para fim de corte da placa e sua posterior caracterização, para a placa 2 foram utilizadas as medidas das placas das extremidades do elemento combustível que possui como especificação de comprimento máximo 825,20 mm. 
Tabela 5.3 - Espessura conjunto laminação durante a laminação a quente

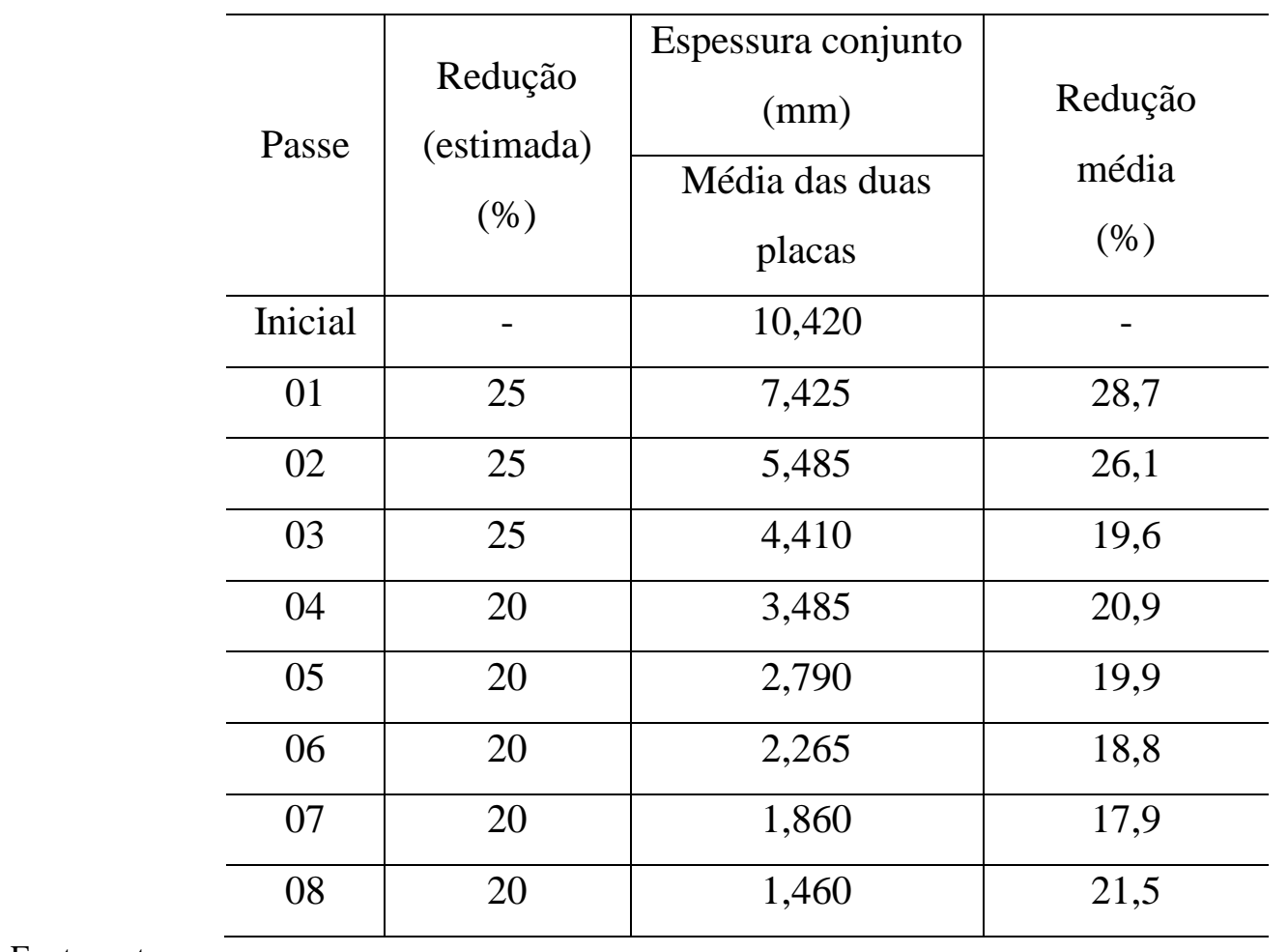

Fonte: autor

As placas foram radiografadas para localização do núcleo e marcação para corte final da placa. A figura 5.17 a mostra uma foto da placa 1 finalizada.

Após o corte final, as placas foram inspecionadas para verificação de suas dimensões. Os valores dimensionais externos das placas 1 e 2 estão apresentados na tabela 5.4 .

Figura 5.17 - Placa combustível finalizada com marcação

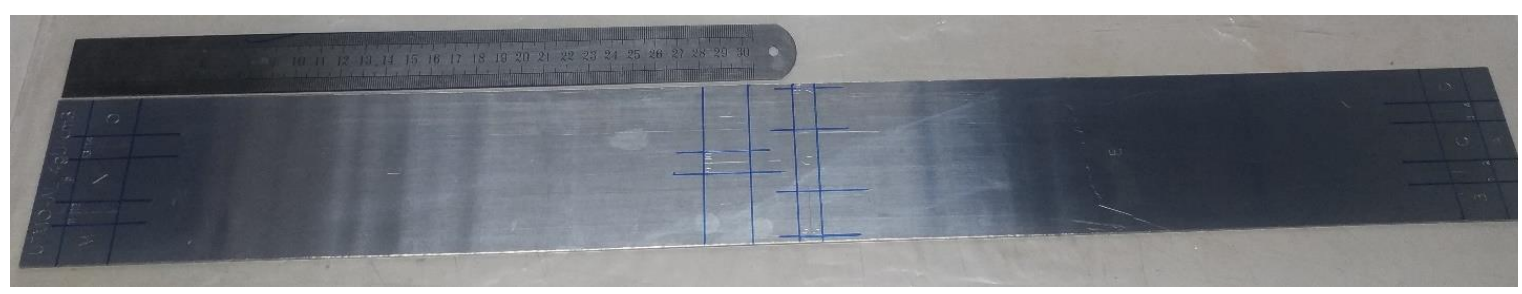

Fonte: autor 
Tabela 5.4 - Medidas dimensionais externas das placas 1 e 2

Fonte: autor

\begin{tabular}{c|c|c|c|c}
\hline & \multicolumn{2}{|c|}{ Placa 1 } & \multicolumn{2}{c}{ Placa 2 } \\
\hline & Max & Min & Max & Min \\
\hline Largura $(\mathrm{mm})$ & 74,91 & 75,07 & 74,91 & 75,32 \\
\hline Comprimento $(\mathrm{mm})$ & 654,34 & 654,59 & 824,92 & 825,17 \\
\hline Espessura $(\mathrm{mm})$ & 1,37 & 1,39 & 1,36 & 1,37 \\
\hline
\end{tabular}

As imagens digitais das radiografias das placas 1 e 2 são apresentadas na figura 5.18 .

Para a placa 1, tem-se um núcleo centralizado com um desvio máximo de 1,1 mm entre a distância do núcleo e a borda do revestimento em vários pontos medidos ao longo da placa. Na figura 5.18 b pode-se notar que as extremidades do núcleo estão levemente mais escuras o que indica a presença de uma camada mais espessa e presença de material físsil. O aumento da espessura nas extremidades é devido ao efeito de dog boning que trata do acúmulo de material durante a laminação por causa das diferenças nas propriedades mecânicas do briquete e do revestimento. Ainda na figura 5.19 a é possível observar uma área esbranquiçada no meio na parte superior da imagem indicando a ausência de combustível nesta região, ou seja, heterogeneidade da dispersão da fase físsil.

Já na figura 5.18 c, nota-se que o núcleo não está centralizado na placa, como pode ser observado pelo arqueamento do núcleo em relação a lateral da placa representada pela linha vermelha na imagem. Este defeito é conhecido como flecha e é formado durante laminação. O desvio máximo da distância entre a lateral da placa e o núcleo foi de 3,7 mm. 
Figura 5.18 - Imagens radiográficas das placas combustíveis 1 (a, b) e 2 (c, d).

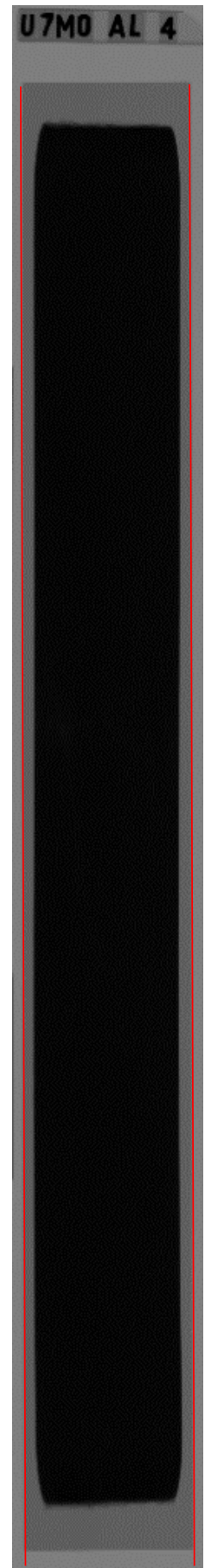

(a)
U7MO AL 4

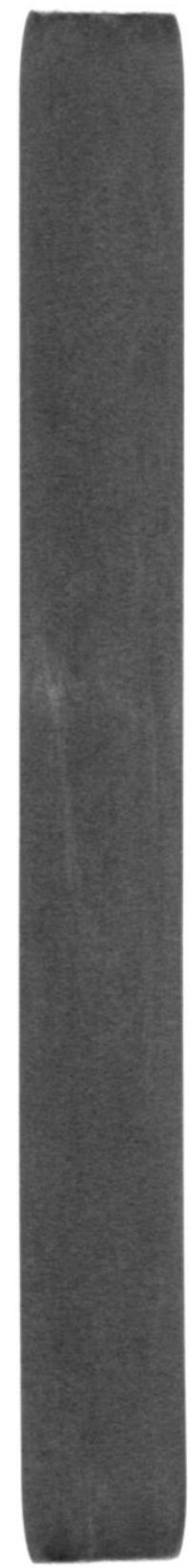

(b)

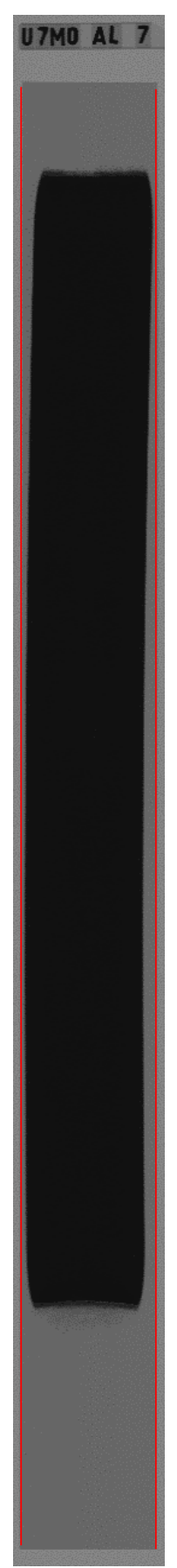

(c)
U7MO AL 7

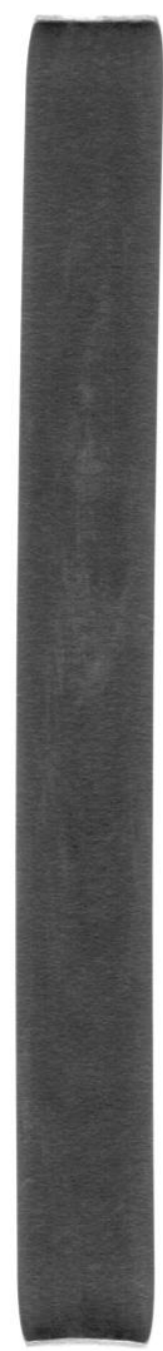

(d)

Fonte: autor 
Na figura 5.18 d, temos uma dispersão heterogênea com manchas brancas no centro da placa combustível indicando a ausência de material combustível no núcleo. Em contrapartida, observa-se que as extremidades possuem um tom mais escuro devido ao acúmulo de partículas de U7Mo.

Também, é possível observar que as imagens apresentam uma perturbação na definição das extremidades dos núcleos que é melhor detalhada na figura 5.19. Esta característica é proveniente de arraste de partículas combustíveis entre a moldura e o revestimento durante a laminação.

Figura 5.19 - Detalhe da extremidade da placa 2 com arraste de partículas combustíveis entre a moldura e revestimento

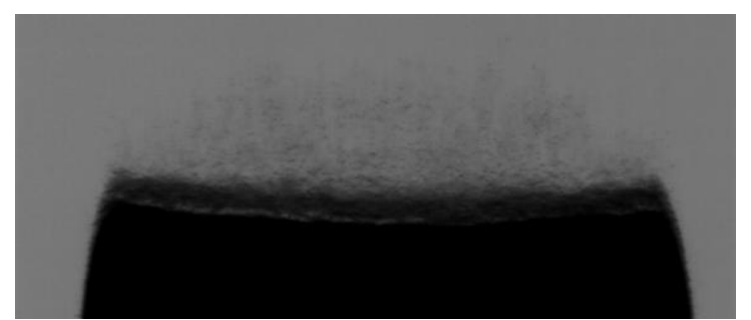

Fonte: autor

As dimensões internas do núcleo foram medidas através das imagens radiografadas e estão apresentados na tabela 5.5.

Tabela 5.5 - Medidas dimensionais internas dos núcleos das placas 1 e 2

\begin{tabular}{c|c|c|c|c}
\hline & \multicolumn{2}{|c|}{ Placa 1 } & \multicolumn{2}{c}{ Placa 2 } \\
\hline & Min & Max & Min & Max \\
\hline Largura (mm) & 64,5 & 65,8 & 65,3 & 66,7 \\
\hline Comprimento (mm) & 615,2 & 618,8 & 635,1 & 638,8 \\
\hline Distância núcleo-borda (mm) & 4,7 & 5,8 & 2,9 & 6,8 \\
\hline
\end{tabular}

Fonte: autor

As placas já cortadas nas dimensões finais foram marcadas novamente para corte conforme esquema da figura 4.10 para análise do interior do núcleo pela técnica de metalografia. Após o corte, as amostras foram embutidas e polidas conforme descrito no 
item 4.5.2 e observadas em microscópio óptico. As imagens obtidas permitiram a análise da dispersão e da espessura do núcleo nas diversas seções de corte ao longo da placa. As figuras 5.20 apresentam as imagens de MO da seção longitudinal das extremidades placas 1 e 2 . Durante o corte, os pedaços para análise da placa 2 abriram indicando que não houve o caldeamento dos revestimentos com o núcleo.

Figura 5.20 - Imagem de microscopia óptica da seção longitudinal na extremidade das placas 1 (a) e 2 (b)

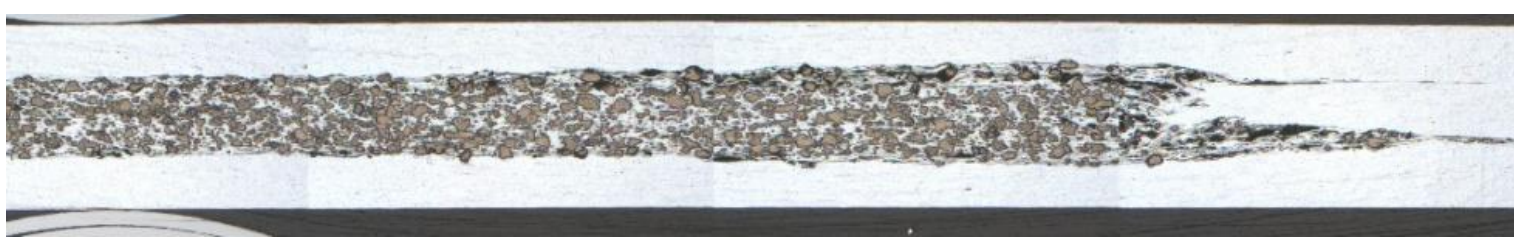

(a)

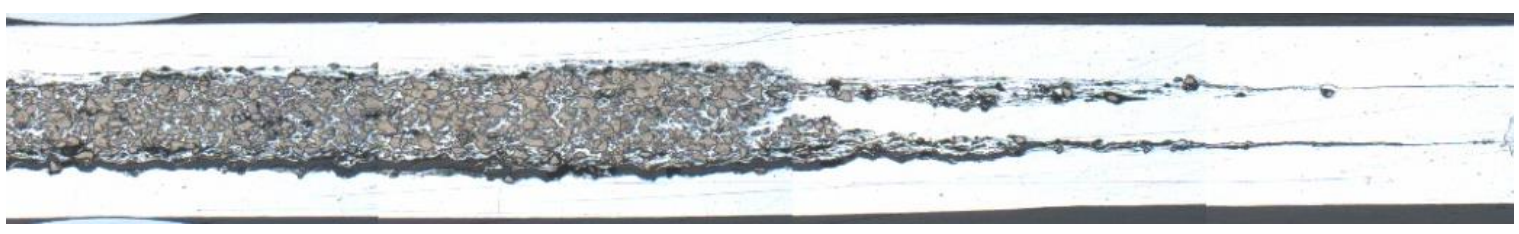

(b)

Fonte: autor

Das imagens da figura 5.20, é possível perceber o arraste acentuado de partículas combustíveis na extremidade dos núcleos e tal arraste é mais acentuado na placa 2. Em ambas as placas, nota-se espaços escuros no interior do núcleo indicando presença de poros com uma tendência maior no sentido longitudinal da placa devido ao processo de laminação.

Na parte de cima da figura 5.21 b pode-se ver que também há presença destes poros e, na base nota-se o total desprendimento do revestimento com o núcleo que ocorreu durante o corte da amostra. Na figura 5.21 a no canto superior direito também é possível observar esta tendência de espaços entre núcleo e revestimento com menor intensidade.

Devido ao dog boning, nota-se que a espessura do revestimento na parte próxima ao final do núcleo está menor do que ao longo da placa.

Com as imagens obtidas nas diversas seções da placa foi possível medir a espessura do revestimento e do núcleo. Como o dog boning é comum na fabricação de placas combustíveis, os valores para extremidade e centro da placa são especificados já com a previsão da ocorrência deste defeito. Na tabela 5.6 são apresentados os valores mínimo e 
máximo para as espessuras dos núcleos e revestimentos das placas 1 e 2 nas extremidades e no centro

Tabela 5.6 - Espessura núcleo e revestimento das placas 1 e 2

\begin{tabular}{c|c|c|c|c|c}
\hline \multicolumn{2}{c|}{} & \multicolumn{2}{c|}{ Placa 1 } & \multicolumn{2}{c}{ Placa 2 } \\
\cline { 3 - 6 } \multicolumn{2}{c|}{} & MIN & MAX & MIN & MAX \\
\hline \multirow{2}{*}{$\begin{array}{c}\text { Núcleo } \\
(\mathrm{mm})\end{array}$} & extremidade & 0,74 & 0,85 & 0,71 & 0,88 \\
\cline { 2 - 6 } & centro & 0,69 & 0,69 & 0,70 & 0,77 \\
\hline $\begin{array}{c}\text { Revestimento } \\
(\mathrm{mm})\end{array}$ & extremidade & 0,28 & 0,40 & 0,22 & 0,36 \\
\cline { 2 - 6 } & centro & 0,35 & 0,42 & 0,09 & 0,41 \\
\hline
\end{tabular}

Fonte: autor

Os valores em vermelho apresentam os pontos fora da especificação . A placa 2 foi a que obteve o maior desvio com espessuras de revestimento bem inferior ao especificado na tabela 4.1 com valores de 0,09 e $0,22 \mathrm{~mm}$.

Foi estimada a porosidade do núcleo no interior da placa a partir da razão densidade hidrostática da placa e da porosidade residual dos briquetes. O cálculo é apresentado na sequência das equações 4,5 e 6.

$$
\begin{array}{cc}
\text { Volume }_{\text {núcleo }}=\frac{m_{\text {placa }}-m_{\text {placa imersa }}}{\rho_{\mathrm{H}_{2} \mathrm{O}}}-\frac{m_{\text {placa }}-m_{\text {núcleo }}}{\rho_{A l}}, & \text { (equação 4) } \\
\rho_{\text {núcleo }}=\frac{m_{\text {núcleo }}}{\text { Volume }_{\text {núcleo }}} & \text { (equação 5) } \\
\text { porosidade }_{\text {núcleo }}=1-\frac{\rho_{\text {núcleo }}}{\rho_{\text {briquete }}} \times 100 & \text { (equação 6) }
\end{array}
$$

As densidades dos núcleos da placa 1 e da placa 2 foram, respectivamente, $5,93 \mathrm{~g} \mathrm{~cm}^{-3}$ e $8,08 \mathrm{~g} \mathrm{~cm}^{-3}$. Comparando com o valor obtido da porosidade residual do briquete, temos por fim as porosidades de $8,77 \%$ e $13,12 \%$ em poros nas placa 1 e 2 , 
respectivamente. Os valores aceitáveis de porosidade para as placas de combustíveis atuais variam entre 6 a $8 \%$.

Das imagens da figura 5.20, observa-se claramente maior aglomeração de partículas na placa 2. Entretanto, visualmente, se percebe que o carregamento de partículas aparenta estar acima da fração volumétrica pretendida no núcleo. Para a placa 1, a fração volumétrica teórica de U7Mo com uma densidade de $\mathrm{U}$ de $4 \mathrm{gU} \mathrm{cm}^{-3}$ é de $26 \%$ e para a placa 2 a fração especificada é de $45 \%$. Foi realizada análise de imagens para estimativa da fração volumétrica de cada núcleo através de software específico pelo contraste de cor entre as partículas e a matriz. A porcentagem da área da imagem representativa das partículas foi estimada como a fração volumétrica do núcleo. As imagens foram obtidas por microscopia eletrônica de varredura e foi feita uma média sobre 6 micrografias tiradas aleatoriamente de cada núcleo. Os valores das análises são apresentados na tabela 5.7 e na figura 5.21 tem-se um exemplo da análise de imagem.

Tabela 5.7 - Frações volumétricas de combustível nos núcleos das placas 1 e 2 estimadas por análise de imagem

\begin{tabular}{c|c|c|c|c}
\hline \multirow{2}{*}{ Imagem } & \multicolumn{2}{|c|}{ Placa $1-4 \mathrm{gU} \mathrm{cm}^{-3}$} & \multicolumn{2}{c}{ Placa $2-7 \mathrm{gU} \mathrm{cm}^{-3}$} \\
\cline { 2 - 5 } & Matriz \% & Partículas \% & Matriz \% & Partículas \% \\
\hline 1 & 64,56 & 35,44 & 44,93 & 55,07 \\
\hline 2 & 65,06 & 34,94 & 39,02 & 60,98 \\
\hline 3 & 54,72 & 45,28 & 48,00 & 52,00 \\
\hline 4 & 59,77 & 40,23 & 52,00 & 48,00 \\
\hline 5 & 63,50 & 37,50 & 46,80 & 53,20 \\
\hline 6 & 54,44 & 45,56 & 46,17 & 53,83 \\
\hline Média & 60,34 & 39,82 & 46,15 & 53,83 \\
\hline
\end{tabular}

Fonte: autor

É possível confirmar a análise visual observada nas imagens da figura 5.21. Os valores da fração volumétrica tanto para a placa 1 quanto para a placa 2 estão muito acima dos valores teóricos calculados para as mesmas com base na densidade obtida pela técnica de picnometria de hélio.

Como observado na figura 5.13, as partículas obtidas pela técnica de hidretaçãomoagem-desidretação apresentam um elevado número de trincas o que proporcionou um 
valor superestimado para a densidade aparente. Parte do volume calculado para ser de matriz foi consumido pela porosidade no interior da partícula. Esta informação resultou em um cálculo equivocado para a obtenção da fração volumétrica no núcleo, especialmente para a placa 2, cuja fração volumétrica foi o parâmetro para cálculo da massa a ser misturada na matriz. Como a pesagem foi feita com base em uma densidade teórica, desconsiderando o volume de poros presentes, o volume de pó foi superior em cerca de $10 \%$ a mais do que o desejado e por isso se observa o carregamento intenso de partículas nos núcleos. Das características das partículas provenientes da técnica HMD, com uma fração volumétrica de $45 \%$ não será possível obter uma densidade de urânio nominal de $7 \mathrm{gU} \mathrm{cm}^{-3}$.

Figura 5.21 - Exemplo de relatório para análise de imagem da seção transversal obtida por MEV do núcleo da placa 2

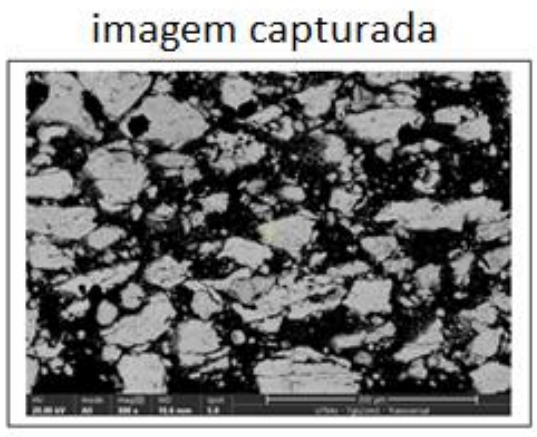

imagem analisada

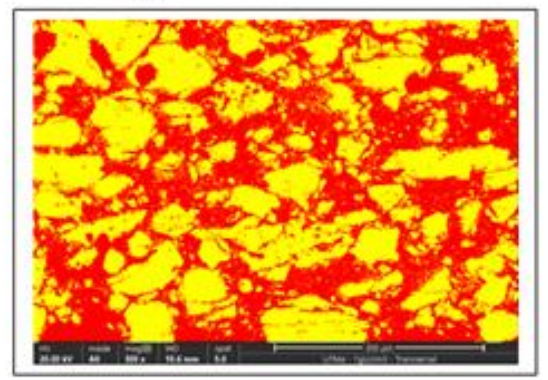

fração superficial

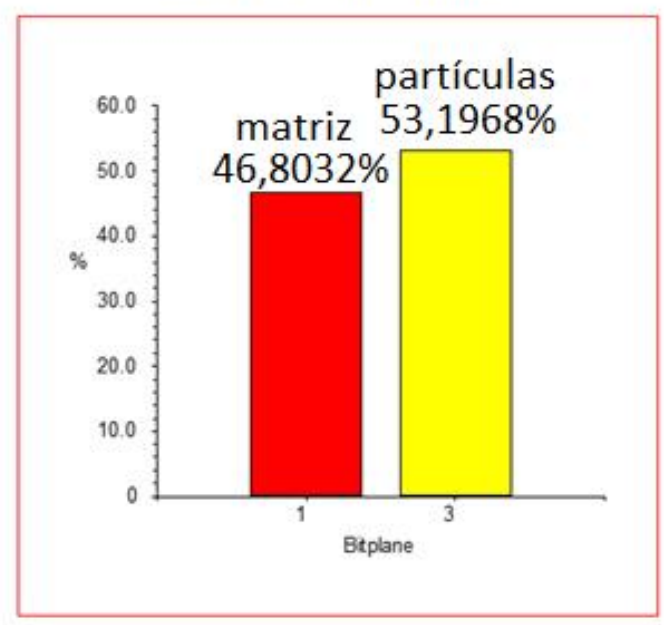

Fonte: autor

As seções dos núcleos das placas 1 e 2 foram analisadas por microscopia eletrônica de varredura com elétrons retroespalhados. Na figura 5.22 são apresentadas imagens das seções longitudinais das placas 1 e 2. 
Figura 5.22 - Imagens MEV seção longitudinal dos núcleos da placa 1 (a, c, e) e da placa 2 (b, d, f).

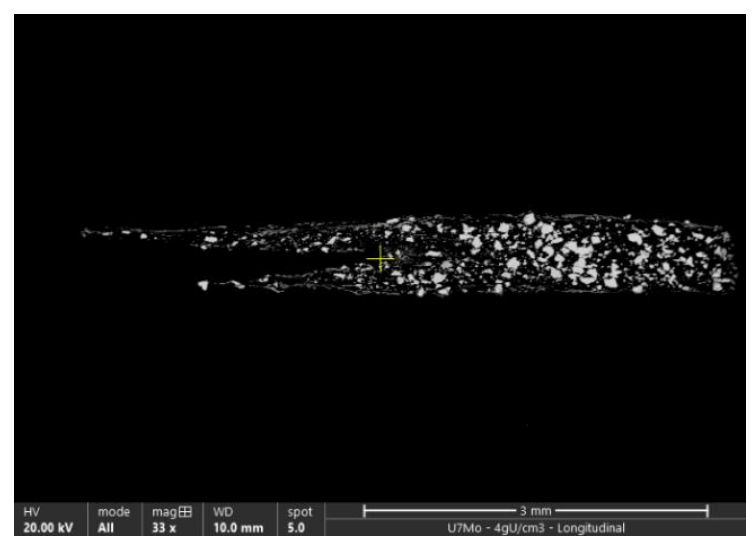

(a)

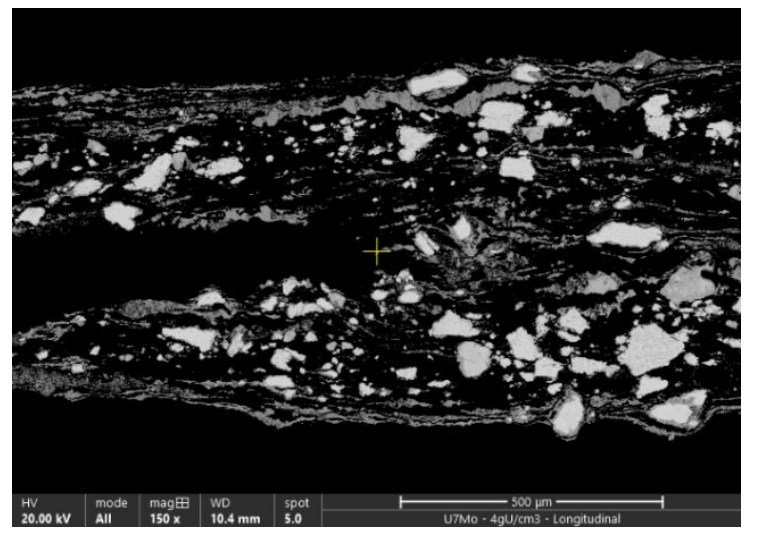

(c)

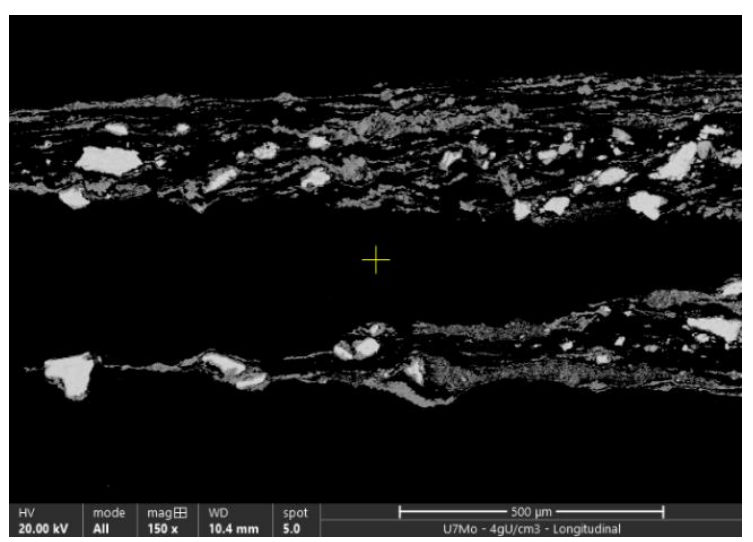

(e)

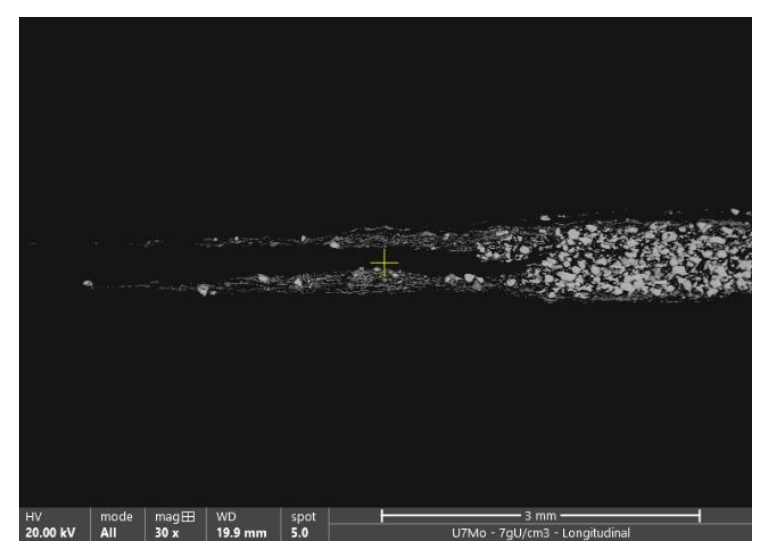

(b)

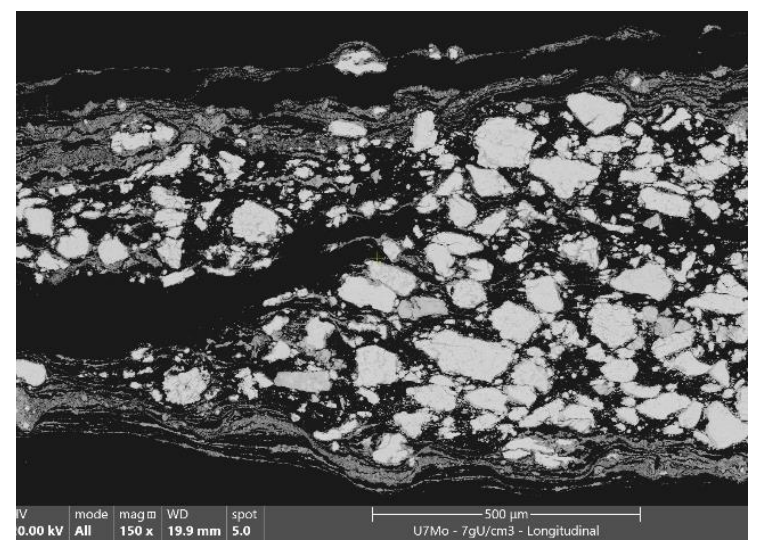

(d)

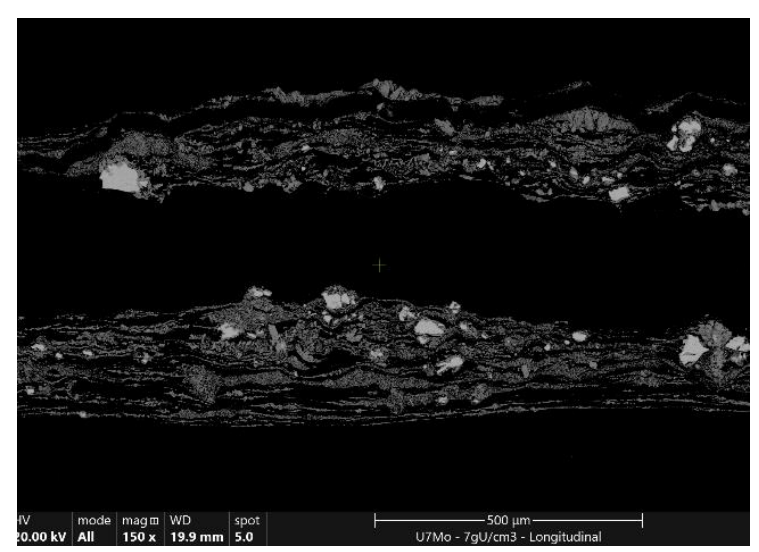

(f)

Fonte: autor

Das imagens a e b da figura 5.22, é possível observar o arraste de partículas na extremidade do núcleo porém com partículas muito finas que parecem definir uma linha 
quase que contínua no contorno do núcleo junto ao revestimento de alumínio. As imagens $5.22 \mathrm{c}, \mathrm{d}, \mathrm{e}, \mathrm{f}$ detalham este arraste.

Também é possível notar tonalidades diferentes de cinza entre as partículas, especialmente na partículas maiores e as mais finas indicando a presença de diferentes fases no interior do núcleo.

Na figura 5.23 são apresentadas imagens no interior do núcleo de uma seção longitudinal e transversal das placas 1 e 2 para investigar a presença destas partículas finas diagnosticadas na extremidade no sentido longitudinal.

Figura 5.23 - Imagens MEV seção longitudinal interior dos núcleos da placa 1 (a) e placa 2 (b) e seção transversal dos núcleos da placa 1 (c) e da placa 2 (d)

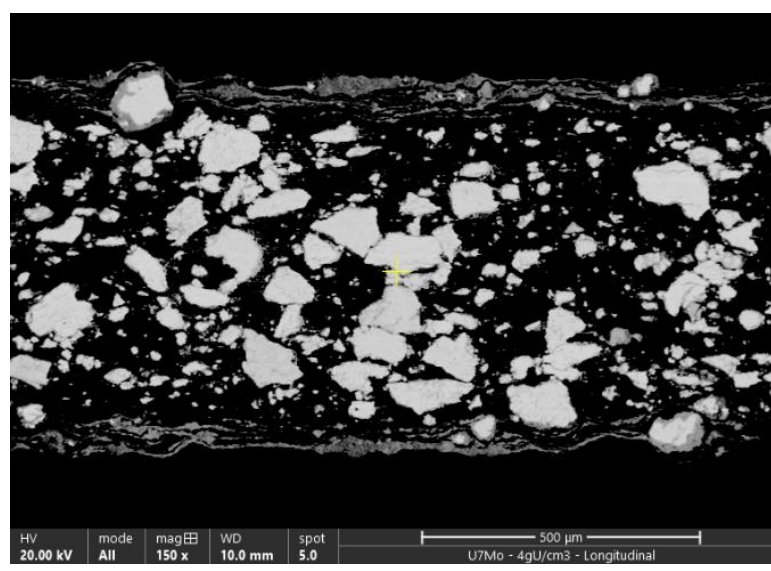

(a)

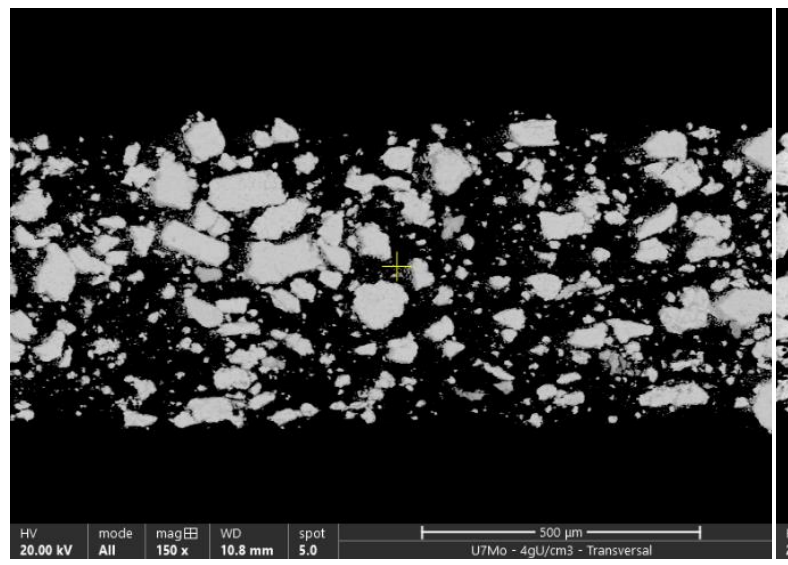

(c)

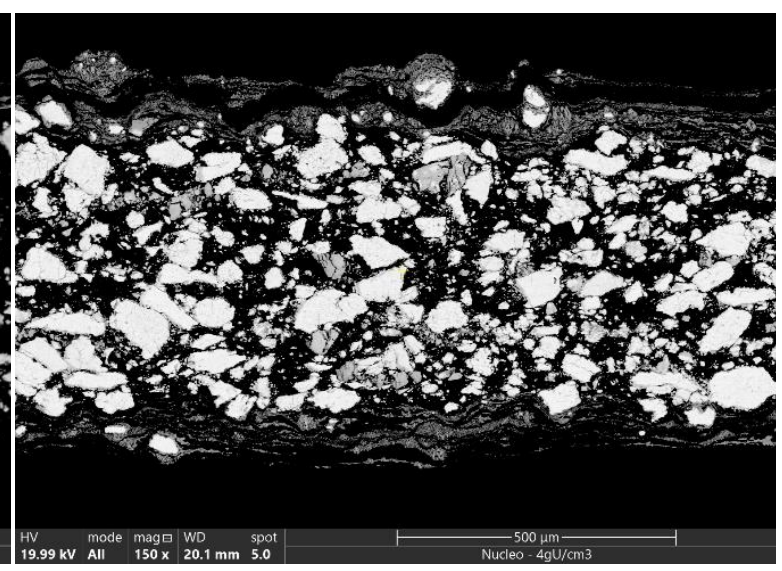

(b)

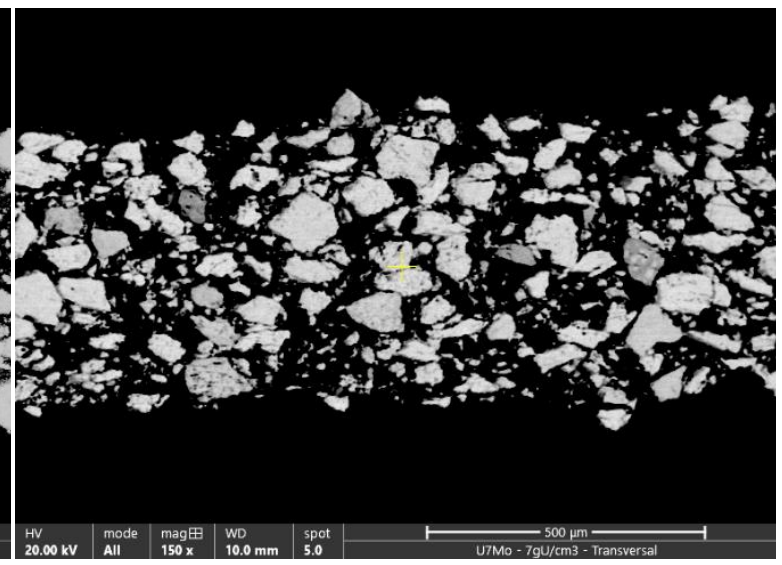

(d)

Fonte: autor

Comparando-se as figuras 5.23 a e $5.23 \mathrm{~b}$ com as figuras 5.23 c e $5.23 \mathrm{~d}$, notase que a linha de partículas finas entre o núcleo e o revestimento são presentes apenas no 
sentido longitudinal do núcleo. No interior do núcleo a presença destes pós finos é bem reduzido. As imagens 5.23 c e 5.23 d no sentido transversal da placa estão com uma aparência bem diferente das longitudinais indicando que a formação deste caminho de partículas finas seguiu o sentido da laminação. Nas imagens ainda é possível perceber que existem partículas com uma tonalidade mais escura, especialmente nas bordas. Pode-se aferir que o processo de laminação fragmentou as partículas combustíveis de U7Mo. Para avaliar este fenômeno foi realizada uma microanálise por EDX. Na figura 5.24 é apresentada as partículas de U7Mo com maior magnificação e na figura 5.25 tem-se o resultado na microanálise ao longo das linhas indicadas.

Figura 5.24 - Imagens MEV com elétrons retroespalhados das partículas U7Mo no interior do núcleo

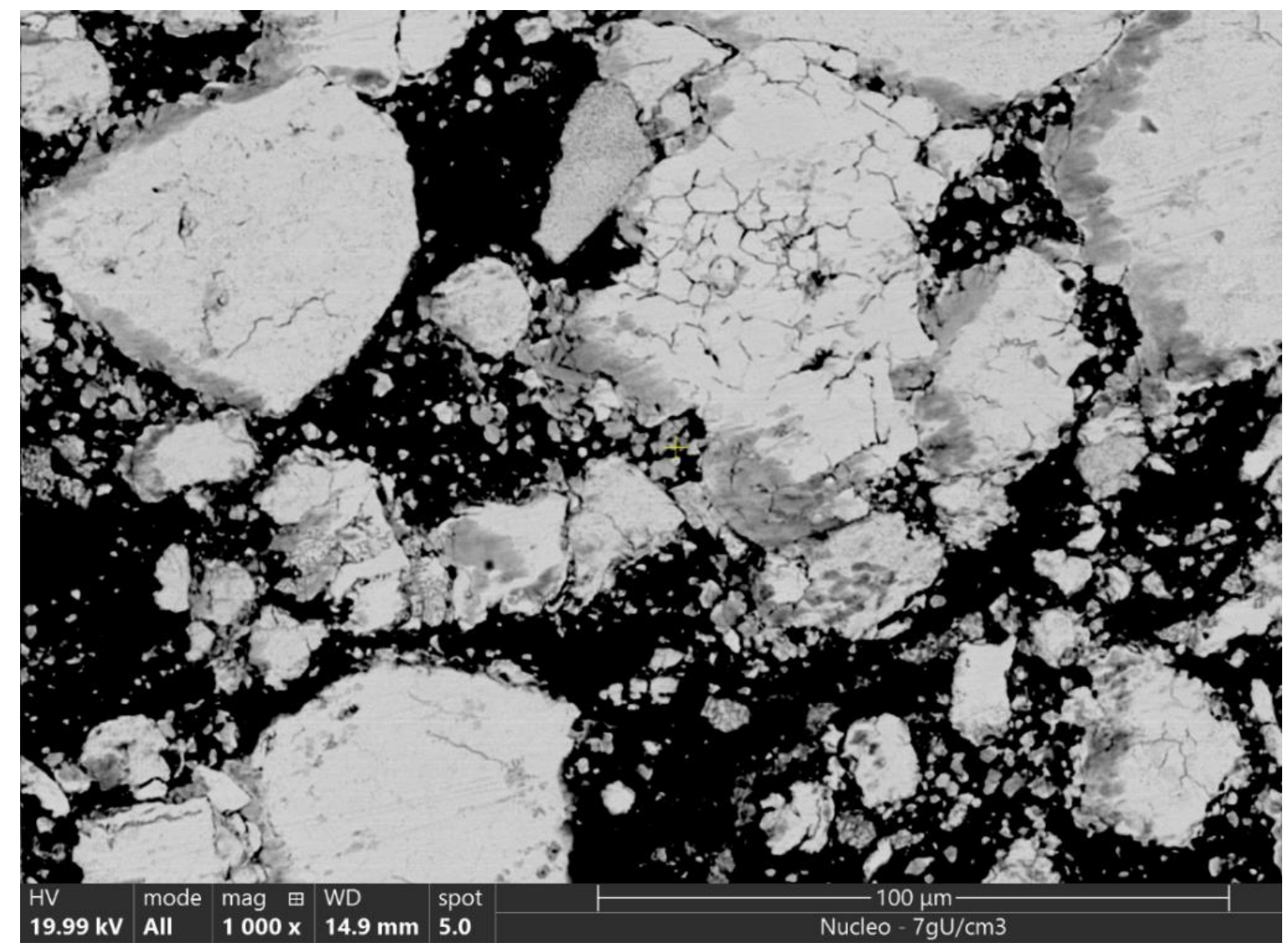

Fonte: autor

Percebe-se que a partícula possui trincas em seu interior e que sua borda está escurecida. Nas proximidades das bordas mais escuras é possível notar que a incidência das partículas finas é maior. Com maior detalhamento se observa que nestas áreas existem 
trincas, diferentes das do interior das partículas, que são intrínsecas ao processo de fabricação por HMD, e que partículas menores estão se desprendendo destas regiões.

Figura 5.25 - Varredura pra identificação de oxidação nas partículas de U7Mo
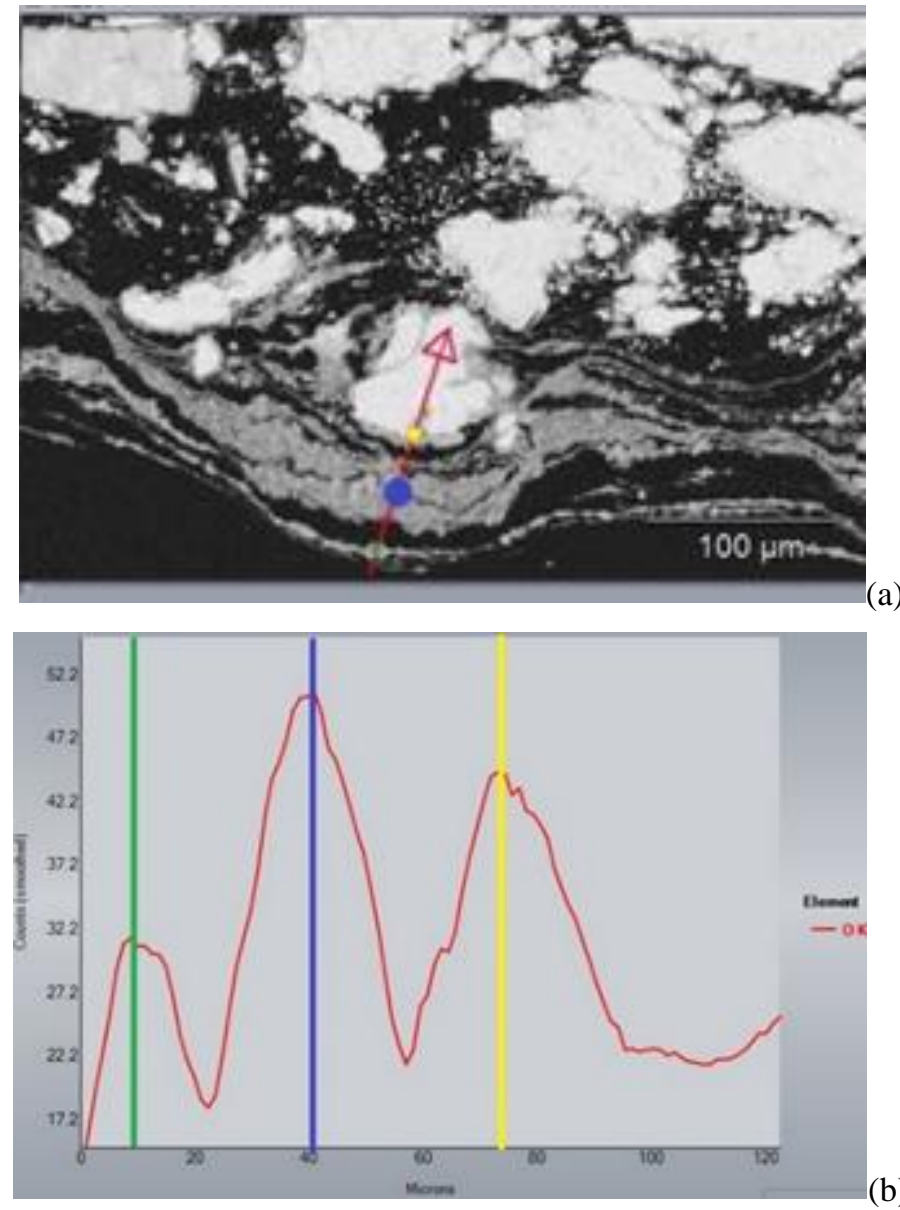

Fonte: autor

A varredura ocorreu no sentido do revestimento para o interior do núcleo como pode ser observado pela seta vermelha na figura 5.25 a. Ao passar por diferentes áreas da amostra, observou-se 3 picos do elemento oxigênio registrados na figura 5.26 b. As linhas coloridas verde, azul e amarelo indicam os picos de $\mathrm{O}$ e estão relacionados aos pontos da mesma cor na imagem 5.25 a. Destes 3 pontos, nota-se que o ponto verde está sobre o arraste de partículas finas observado na interface do núcleo com o revestimento, diminui quando passa por uma parte da matriz de $\mathrm{Al}$, no ponto azul, novamente sobre as partículas finas existe outro pico de oxigênio e por fim, o pico amarelo é referente ao ponto na borda escurecida de uma partícula combustível. Para corroborar o diagnóstico das partículas 
oxidadas foi realizado o mapeamento elementar por EDX para Al, O, U, Mo apresentado na figura 5.26 .

Figura 5.26 - Imagem de partículas combustíveis U7Mo no interior do núcleo e respectivos mapas EDX dos elementos Al, O, U e Mo

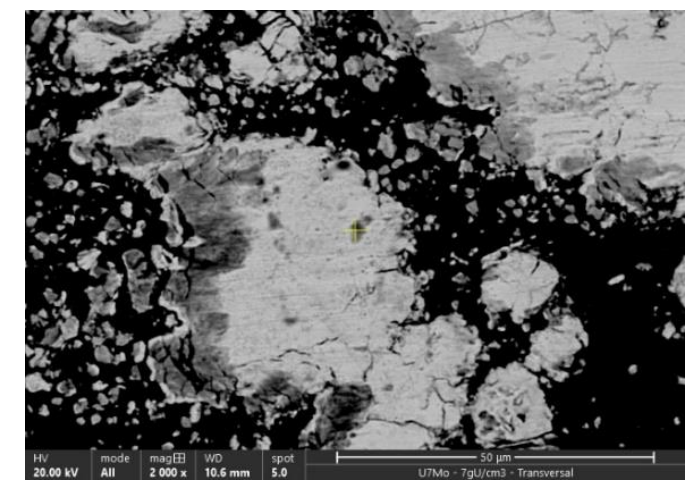

$\mathrm{O}$

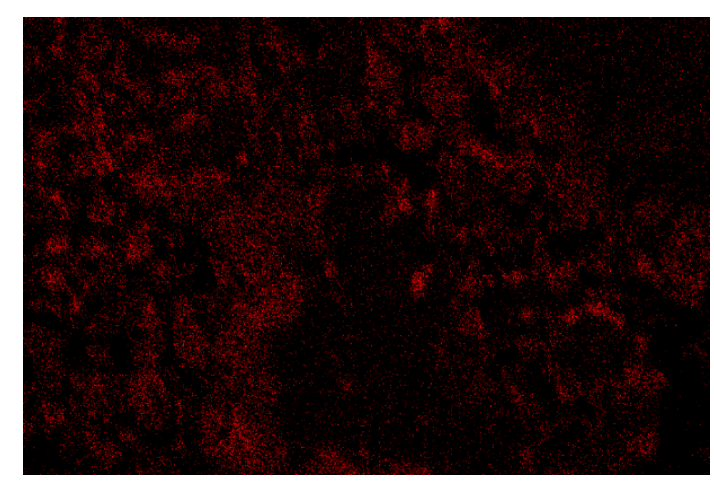

Mo

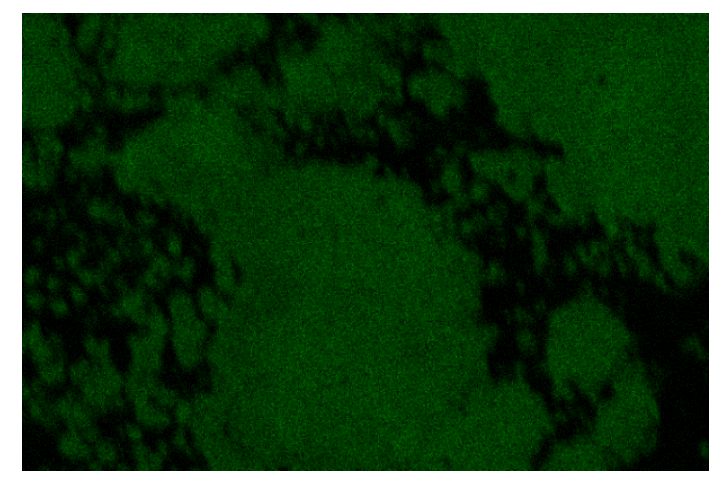

Fonte: autor

Os mapas de matriz Al e combustível U7Mo são complementares como era de se esperar. Já no caso do mapa e O, observa-se intensificação de sua concentração nas áreas
Al

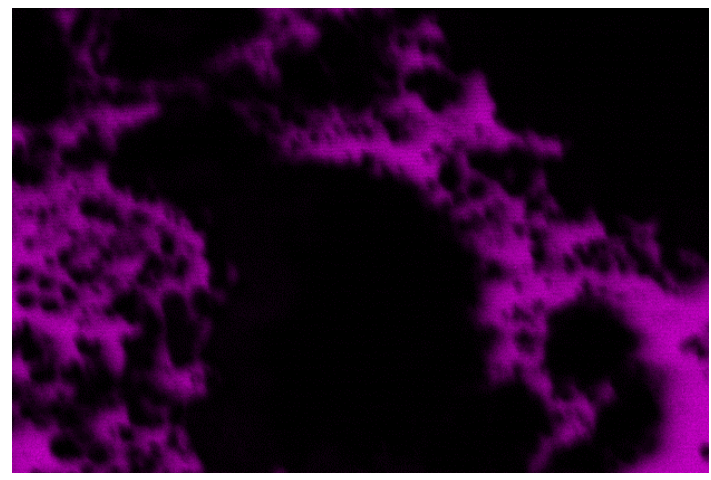

$\mathrm{U}$

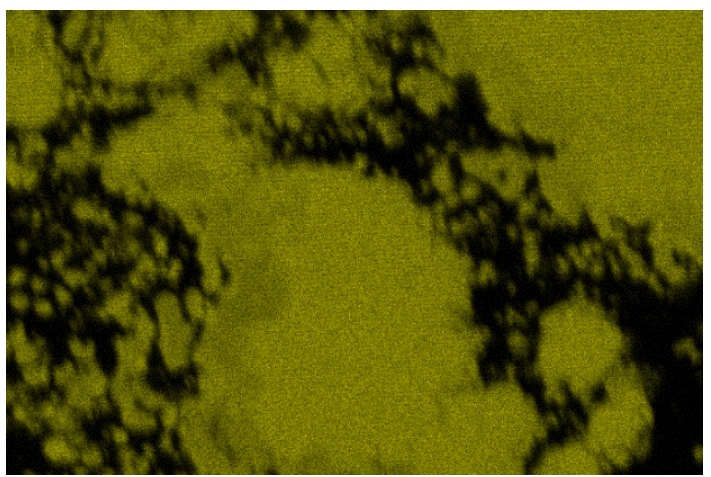


respectivas às regiões escuras das bordas das partículas maiores assim como nas partículas menores desprendida daquelas das mesmas.

Na micrografia utilizada para o mapeamento nota-se com clareza a oxidação existente pelo tom de cinza mais escuro nas bordas da partícula. Observa-se também a presença de trincas nesta região e o desprendimento de partículas finas. A oxidação do U7Mo altera a propriedade mecânica da partícula combustível, ou seja, de uma liga metálica dúctil e dura obtêm-se um óxido frágil que é fragmentado durante o processo de laminação, daí a formação das partículas finas observadas e o sentido de arraste longitudinal a laminação da placa.

É possível aferir que as partículas entre o núcleo e os revestimentos foram as que mais se oxidaram devido a presença de partículas finas de óxido nesta interface, como observado nas imagens das figuras 5.23 a e 5.23 b. Esta informação dá indícios de que esta oxidação ocorreu nas etapas após fabricação do briquete, pois do contrário a oxidação estaria acentuada também no interior do núcleo. Durante o processo de fabricação do combustível, após a fabricação do pó, ocorre a compactação onde o briquete é desgaseificado a $250{ }^{\circ} \mathrm{C}$, a montagem do conjunto moldura, briquete e revestimentos, a soldagem e o aquecimento antes dos passes de laminação a temperatura de $440{ }^{\circ} \mathrm{C}$ em forno. Sugere-se que o aquecimento deste material nestas diferentes etapas em atmosfera com oxigênio presente seja a causa para a oxidação das partículas do núcleo.

Ainda sobre a interface revestimento e núcleo, o diagnóstico da existência desta linha de partículas finas de óxidos entre ambas as partes foi o que não permitiu o caldeamento do núcleo com os revestimentos pela ausência de matriz na região. Como na placa 2, a concentração de partículas é muito maior que na placa 1, houve maior número de partículas oxidadas nas superfícies e ocorreu a abertura da placa durante o corte para análise.

A atual instalação para fabricação do combustível a base do $\mathrm{U}_{3} \mathrm{Si}_{2}$ exposta a atmosfera ambiente não é compatível com a reatividade do U7Mo para as etapas de fabricação da placa combustível. 


\section{CONCLUSÃO}

O trabalho foi desenvolvido com base nos parâmetros de fabricação existentes para o atual combustível a base de $\mathrm{U}_{3} \mathrm{Si}_{2}$ para um padrão de comparação e início da pesquisa.

Frente ao objetivo do desenvolvimento das etapas de fabricação de combustíveis a base e U7Mo, seguem-se as conclusões.

Quanto a etapa de fusão da liga:

- a fusão, nas condições realizadas, apresentou nível de oxidação no lingote a ser hidretado. Este oxigênio pode ser proveniente da pressão de vácuo não suficiente para inertização total do sistema;

- a fusão no formato retangular com uma espessura de $4 \mathrm{~mm}$ resultou em um lingote com diferentes tamanhos de grão ao longo do mesmo.

- todo o molibdênio incorporou à rede cristalina do urânio e estabilizou a fase $\gamma$ assim como esperado.

- observou-se a presença de UC no lingote, sendo mais provável sua precedência do lingote de uranio puro utilizado como matéria prima.

Quanto ao processo HMD:

- o início da hidretação foi irregular para diferente partes da peças hidretadas. $\mathrm{Na}$ primeira hidretação partes foram totalmente fragmentadas enquanto partes ficaram intactas, não sendo possível identificar o porquê desta diferença.

- o aumento de pressão na retorta durante os ciclos consecutivos de hidretação indicam a ocorrência de hidretação do ciclo anterior devido ao desprendimento de gás hidrogênio no metal durante o aquecimento no ciclo.

- o sistema no qual o processo de HMD foi realizado promoveu oxidação da liga com a indicação do aumento da concentração de óxido no pó final. Sugere-se a melhora do vácuo do sistema para minimizar tal efeito.

- a moagem é altamente responsável pelo rendimento do pó final. Fatores como intensidade, tempo e quantidade de massa no almofariz podem interferir no rendimento final de fabricação de pó gerando mais finos ou aumentando número de ciclos HMD. 
- o pó produzido possui uma forma irregular com pontas e trincas nas partículas, indicando porosidade na partícula que compromete a fração volumétrica de combustível desejada na matriz e diminui a densidade de U no núcleo.

- o rendimento obtido da etapa HMD foi de $74 \%$ sendo acima de estudos apresentados na literatura.

Quanto ao processo de fabricação do briquete:

- a carga atual utilizada para a compactação do briquete não foi suficiente para obtenção da espessura desejada para o briquete 2 e o briquete 1 ficou no limite superior do valor desejado;

- a extração do briquete na matriz da prensa ocasionou ranhuras nas laterais dos briquetes e trincas nas quinas que podem vir a comprometer a próxima etapa da laminação;

Quanto a etapa de laminação e corte:

- Ambas as placas obtiveram arraste de material entre moldura e revestimento, especialmente a placa 2, cujo briquete estava com espessura acima da especificada após compactação.

- As dimensões do núcleo e revestimento para ambas as placas ficaram fora da especificação, especialmente para a placa 2 com maior densidade de urânio.

- A oxidação das partículas nas superfícies do núcleo entre os revestimentos gerou partículas finas fragmentadas e arrastadas durante a laminação não permitindo o caldeamento da placa 2 e comprometendo o caldeamento da placa 1.

Por fim, os resultados indicaram que as instalações atualmente existentes no CCN e o processamento empregado na fabricação de combustíveis à base de siliceto de urânio precisam ser readequados para a fabricação de um combustível à base de U7Mo, mais reativo e propenso à oxidação, especialmente quanto à inertização dos processos de fabricação do briquete e laminação. Além das diferenças no processo de fabricação inerente às propriedades dos materiais, observa-se que o aumento da densidade de urânio no núcleo do combustível afeta o processo, sendo que a placa 2 obteve resultados inferiores quando comparados a placa 1. 


\section{SUGESTÕES PARA TRABALHOS FUTUROS}

- Estudo aprofundado da fabricação do lingote e suas características que afetam a hidretação; - Quantificar a hidretação por meio das medidas de fluxo de hidrogênio, pressão no sistema e massa a ser hidretada;

- Otimizar o sistema de moagem e peneiramento de tal maneira que ao moer as partículas com a granulometria desejada já sejam separadas a fim de evitar o excesso de partículas muito finas;

- Quantificar o acréscimo de oxidação nas diferentes etapas de fabricação;

- Identificar qual o tamanho de partícula ideal para a dispersão de uma liga U7Mo e como minimizar a porosidade na partícula produzida por esta técnica;

- Estudo para otimização do valor para compactação do pó para fabricação do briquete considerando qual a carga determinada massa de U7Mo;

- Inertização dos processos que podem vir a gerar oxidação das partículas de combustível no núcleo da placa 


\section{REFERÊNCIAS BIBLIOGRÁFICAS}

[1] TERremoto, L. A. A. Tipo de Reatores Nucleares. Fundamentos de Tecnologia Nuclear - Reatores. São Paulo, 2004, p. 91-116.

[2] DURAZZO, M. RIELla, H. G. Riella, Procedures for manufacturing nuclear research reactor fuel elements. Saarbrücken, Germany: OmniScriptum GmbH\&Co. KG, 2015.

[3] U.S. DEPARTMENT OF ENERGY Reduced Enrichment for Research and Test Reactors. Nuclear Engineering Division at Argonne, Disponível em <http:// www.rertr.anl.gov>. Acesso em: 04 novembro 2019.

[4] SALLER, H. Preparations properties and cladding of aluminum uranium alloys. Nuclear Science and Technology (Extracts from Journal of Mettalurgy and Ceramics Issue Number 1 to 6), p. 1-12, 1955.

[5] THURBER, W. C., BEAVER R. Segregation in uranium-aluminum alloys and its effect on the the fuel loading of aluminum-base fuel element. USAEC Reactor Fuel Measurements Techniques Symposium, p. 9-29, 18-20 junho 1958.

[6] SNELGROVE, J. L., DOMAGALA, R. F., HOFMAN, G. L., WIENCEK, T. C. The use of U3Si2 dispersed in aluminum in plate-type fuel elements for research and test reactors. Argonne National Laboratory, outubro 1987

[7] COPELAND, G. L., HOBBS, R. W. Hobbs, HOFMAN, Hofman, SNELGROVE, J. L. Performance of low-enriched U3Si2-Aluminum dispersion fuel elements in the Oak Ridge Research Reactor. Oak Ridge National Laboratory and Argonne National Laboratory

[8] U.S. NUCLEAR REGULATORY COMMISSION, Safety Evaluation Report related to the evaluation of low-enriched uranium silicide-aluminum dispersion fuel for use in nonpower reactors. NUREG-1313, julho 1988

[9] SAliBA, A. M., CARVAlHO, E. F. U., RIEELA, H. G., DURAZZO, M. Research reactor fuel fabrication to produce radioisotopes. Applications in Physical Sciences, cap 2, p 21-54, 2011

[10] REST, J., KIM, Y. S., HOFMAN, G. L., MEYER, M. K., HAYES, S. L. U-Mo Fuel Handbook. RERTR Program Argonne National Laboratory,v.1 junho 2006.

[11] DOTAN, A. L., MOURA NETO, C. Estudo de transformação de fase em ligas de urânio-molibdênio submetidas a tratamentos térmicos. Revista Brasileira de Aplicações de Vácuo, vol. 11, nº 2, pp. 85-90, 1992

[12] MEYER, M. K., HOFMAN, G. L., HAYES, S. L., CLARK, C. R., WIENCEK, T. C., SNELGROVE, J. L., STRAIN, R. V., KIM, K. -H. Low-temperature irradiation behavior 
of uranium-molybdenum alloy dispersion fuel. Journal of Nuclear Materials , pp. 221-236, 1 abril 2002

[13] WALDRON, M. B., BURNETT, R. C., PUGH, S. F. The mechanical properties of uranium-molybdenum alloys. United Kingdon Atomic Energy Authority, Harwell, Berkshire, 1958

[14] ZHANG, X., YANG, Z., MENG, Y., KANG, S., HE, J. Influence of Mo content on the gamma-phase stability and properties of $U$-Mo alloy. IOP Confecerence Series: Material Science and Engineering, 2017

[15] OLIVEIRA, F. B. V., DURAZZO, M., CARVALHO, E. F. U., SALIBA-SILVA, A. M. Powder formation of gamma-uranium-molybdenum alloys via hydration-dehydration. Em: International Meeting on Reduced Enrichment for Research and Test Reactors, Praga, República Tcheca, 2007

[16] SOlONIN, M. I., VATUlin, A. V., STETSKY, Y. A., TRIFONOV, Y. I., ROGOZKIN, B. D. Development of the method of high density fuel comminution by hydride-dehydride processing. Em: International Meeting on Reduced Enrichment for Research and Test Reactors, Las Vegas, EUA, 2000

[17] OLOFSON, C. T., MEYER, G. E., HOFFMANNER, A. L. Processing and applications of depleted uranium alloy products. Metals and Ceramics Information Center, Columbus, Ohio, 1976

[18] HOFMAN, G. L., KEYER, M. K., PARK, J. -M. Observations on the irradiation behavior of $\boldsymbol{U}$-Mo alloy dispersion fuel. Em: International Meeting on Reduced Enrichment for Research and Test Rectors, Las Vegas, Nevada, 2000

[19] HOFMAN, G. L., MEYER, M. K. Progress in irradiation performance of experimental uranium-molybdenum dispersion fuel. Em: International Meeting on Reduced Enrichment for Reseach and Test Reactors, San Carlos de Bariloche, Argentina, 2002

[20] HOFMAN, G. L., KIM, Y. S., RYU, H. J., FINLAY, M. R. Improved irradiation behavior of uranium-molybdenum/aluminum dispersion fuel. Em: Research Reactor Fuel Management and Meeting of the International Group on Reactor Research, Lyon, France, 2007

[21] DUBOIS, S., NOIROT, J., GATT, J. M., RIPERT, M., LEMOINE, P., BOULCOURT, P. Comprehensive overview on iris program: irradiation tests and pie on high density $U$ Mo/Al dispersion fuel. Em: Research Reactor Fuel Management and Meeting on the International Group on Reactor Research, Lyon, France, 2007

[22] VAN DEN BERGHIE, S., LEMOINE, P. Review of 15 years of high-density lowenriched $U$-Mo dispersion fuel development for research reactors in europe. Nuclear Engineering Technology, vol. 46, nº 2, pp. 125-146, abril 2015 
[23] WU, S., TAHK, Y. W., YIM, J. S., KIM, H. J., KONG, E. H., OH, J. Y., LEE, B. H., JEONG, Y. J., KIM, S. H., PARK, J. M. Status of U-Mo fuel qualification program \& KJRR project in Korea. Em: 39th International Meeting on Reduced Enrichment for Research and Test Reactors, Edinburgh, Scotland, 2018

[24] LAINETTI, P. E. O. Fundamentos de Tecnologia Nuclear - Materiais e Ciclo do Combustível Nuclear - Apostila 2, São Paulo, 2013

[25] LEAL NETO, R. M. Estudo de processos de obtenção de pó de U3O8 empregado em elementos combustíveis do tipo MTR. 1089 138p. Dissertação (Mestrado em Tecnologia Nuclear) Instituto de Pesquisas Energéticas e Nucleares, São Paulo

[26] ASM INTERNATIONAL Powder metal technologies and applications. ASM Handbook, vol. 7, 1998

[27] PASQUALINI, E. E. Pasqualini, LOPEZ, M., GARCIA, J. H., ECHENIQUE, P., ADELFANG, P. Scalling up the production capacity of $U$-Mo powder by HMD process. Em: International Meeting on Reduced Enrichment for Research and Test Reactors, San Carlos de Bariloche, Argentina, 2002

[28] CHAMPUON, G. Champion, BELIN, R., PALANCHER, H., ILTIS, X., ROUQUETE, H., PASTUREL, M., DEMANGE, V., CASTANY, P., DORCET, V., TOUGAIT, O. Development of characterisation methods on $U(M o)$ powders for material testing reactors (MTRs). Powder Technology, vol. 255, pp. 29-35, 2014

[29] CLARK, C. R., MEYER, M. K., STRAUSS, J. T. Fuel powder production from ductile uranium alloys. Em: International Meeting on Reduced Enrichment for Research and Test Reactors, São Paulo, Brasil, 1998

[30] JUNGWIRTH, R., PALANCHER, H., BONNIN, A., BERTRAND-DRIRA, C., BORCA, C., HONKIMÄKI, V., JAROUSSE, C., STEPNIK, B., PARK, S. -H., ILTIS, X., SCHMAHL, W. W., PETRY, W. Microstructure of as-fabricated U-Mo/Al(Si) plates prepared with ground and atomized powder. Journal of Nuclear Materials, $n^{\circ} 438$, pp. 246260, 2013

[31] CABANILLAS, E. D., LÓPEZ, M., PASQUALINI, E. E., CIRILO LOMBARDO, D. J. Production of uranium-molybdenum particles by spark-erosion. Journal of Nuclear Materials, $n^{\circ} 324$, pp. 1-5, 2004

[32] AllenOU, J., BROTHIER, M., CHARROlAiS, F., ILTIS, X., TOUGAIT, O., PASTUREL, M., NOEL, H. Methos for preparing a powder of an alloy based on uranium and molybdenum. Estados Unidos da América Patente 9.190.180 B2, 17 novembro 2015 
[33] AllENOU, J., CHAROLlAis, F., BROTHIER, M., ILTIS, X., TOUGAIT, O., PASTUREL, M., NOEL, H. Powder of an alloy based on uranium and on molybdenum useful for manufacturing nuclear fuels and targets intended for producing radioisotopes. Estados Unidos da América Patente 9.574.257 B2, 21 fevereiro 2017

[34] HAVELA, L., KIM-NGAN, N. T. H. Hydrogen absorption in uranium-based alloys with cubic gamma-U structure. Advances in Natural Sciences: Nanoscience and Nanotechnology, $\mathrm{n}^{\mathrm{o}}$ 8, 2017

[35] BANOS, A., HARKER, N. J., SCOTT, T. B. A review of uranium corrosion by hydrogen and the formation of uranium hydride. Corrosion Science, vol. 136, pp. 129-147, 2018

[36] SUPARDJO, KADARJONO, A., BOYBUL Influence of U-Mo powder by mechanical and hydride-dehydride -grinding mill process result of $U$-Mo/Al fuel plate quality. Urania, vol. 21, n 2 , pp. 47-56, 2015

[37] BALART, S., BRUZZONI, P., GRANOVSKY, M., GRIBAUDO, L., HERMIDA, J., OVEJERO, J., RUBIOLO, G., VICENTE, E U-Mo alloy powder obtained by a hydridedehydride process. Em: International Meeting on Reduced Enrichment for Research and Test Reactors, Las Vegas, Nevada, 2000

[38] FAÊDA, K. C. M., SANTOS, A. M. M., PAUlA, J. B., PEREIRA, E. M., PEDROSA, T. A., LAMEIRAS, F. S., FERRAZ, W. B. Comminution of the U-10Mo by hydriding cycles innovative process. Em: International Nuclear Atlantic Conference, Recife, 2013

[39] BAZLEY, S. G., PETHERBRIDGE, J. R., GLASCOTT, J. The influence of hydrogen pressure and reaction temperature on the initiation of uranium hydride sites. Solid State Ionics, vol. 211, pp. 1-4, 2012

[40] PETHERBRIDGE, J. R., KNOWLES, J., BAZLEY, S. G. The effect of thermal pretreatments on the nucleation of uranium hydride. Solid State Ionics, vol. 292, pp. 110-115, 2016

[41] KNOWLES, J. P., FINDLAY, I. M. The influence of vacuum annealing on the uranium-hydrogen reaction. Jounal of Alloys and Compounds, vol. 645, pp. S230-S233, 2015

[42] BANOS, A., STITT, C. A., SCOTT, T. B. Scott The effect of sample preparation on uranium hydriding. Corrosion Science, vol. 113, pp. 91-103, 2016

[43] PASQUALINI, E. E., GARCIA, J. H., CABANILlAS, E., ADELFANG, P. Powder production of $U$-Mo alloy, HMD process (Hydriding-Milling-Dehydriding). Em: 6th International Topical Meeting on Research Reactor Fuel Management, Belgium, 2002

[44]LEAL NETO, R. M., ROCHA, C. J., CARVALHO, E. U., RIELLA, H. G., DURAZZO, M. Investigation of powdering ductile gamma u-10wt\%Mo alloy for dispersion fuel. Journal of Nuclear Materials, vol. 445, pp. 218-223, 2014 
[45] DURAZZO, M., ROCHA, C. J., MESTNIK FILHLO, J., LEAL NETO, R. M., Fabrication of powder from ductile $U$-Mo alloys for use as nuclear dispersion. Em: 8th International Latin American Conference on Powder Technology, Florianópolis, SC, 2011

[46] PASQUALINI, E. E. Alternative processes of comminution and colamination of uranium molybdenum alloys. Progress in Nuclear Energy, vol. 75, pp. 92-104, 2014

[47] PASQUALINI, E. E., LÓPEZ, M., GONZALEZ, A. A set up U-Mo powder production by HMD process. Em: International Meeting on Reduced Enrichment for Research and Test Reactors, Chicago, EUA, 2004

[48] XIONG, Y. -F., MIAO, C., JING, W. -Y., CHEN, C. -A. Manufacturing of $\boldsymbol{U}$ 10wt\%Mo powder by hydride-dehydride processing. Fusion Engineering and Design, vol. 85 , pp. 1492-1495, 2010

[49] CHEN, M., XIONG, Y.-F., JING, W. -Y., JIA, J. -P., ZHANG, P. -C. Characterization of gamma-U-10wt\%Mo alloy powder obtained by hydriding-milling-dehydride proces. Journal of Nuclear Materials, vol. 400, pp. 69-72, 2010 
INSTITUTO DE PESQUISAS ENERGÉTICAS E NUCLEARES

Diretoria de Pesquisa, Desenvolvimento e Ensino

Av. Prof. Lineu Prestes, 2242 - Cidade Universitária CEP: 05508-000

Fone/Fax(0XX11) 3133-8908

SÃO PAULO - São Paulo - Brasil

http://www.ipen.br

O IPEN é uma Autarquia vinculada à Secretaria de Desenvolvimento, associada à Universidade de São Paulo e gerida técnica e administrativamente pela

Comissão Nacional de Energia Nuclear, órgão do

Ministério da Ciência, Tecnologia, Inovações e Comunicações. 